\title{
Distribuição, taxa de entrada, composição química e identificação de fontes de grânulos plásticos na Enseada de Santos, SP, Brasil
}

\begin{abstract}
Dissertação apresentada ao Instituto Oceanográfico da Universidade de São Paulo, como parte dos requisitos para obtenção do título de Mestre em Ciências, área de Oceanografia Biológica
\end{abstract}

Orientador: Prof. Dr. Alexander Turra

\section{São Paulo}


Universidade de São Paulo

Instituto Oceanográfico

Distribuição, taxa de entrada, composição química e identificação de fontes de grânulos plásticos na Enseada de Santos, SP, Brasil

Aruanã Bittencourt Manzano

Dissertação apresentada ao Instituto Oceanográfico da Universidade de São Paulo, como parte dos requisitos para obtenção do título de Mestre em Ciências, área de Oceanografia Biológica.

Julgada em

$\operatorname{Prof(a).} \operatorname{Dr}(\mathrm{a})$

Conceito

$\operatorname{Prof(a).~Dr(a).~}$

Conceito

Prof(a). Dr(a).

Conceito

$\operatorname{Prof}(a) \cdot \operatorname{Dr}(a)$

Conceito

Prof(a). Dr(a).

Conceito 


\section{SUMÁRIO}

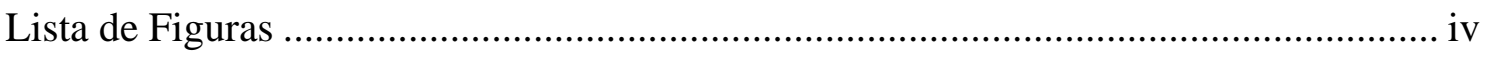

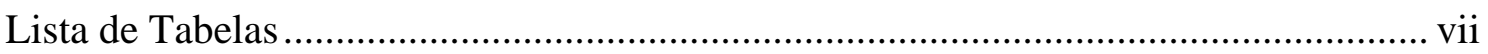

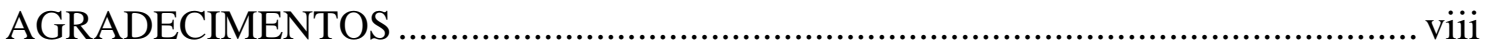

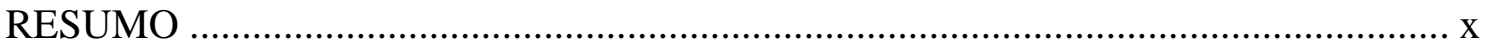

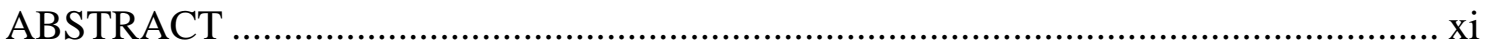

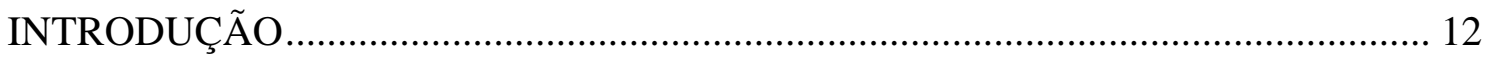

Plásticos no mundo: importância, características e produção .................................... 12

Impactos: Estéticos, Econômicos e Ecológicos........................................................... 17

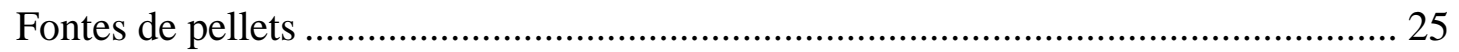

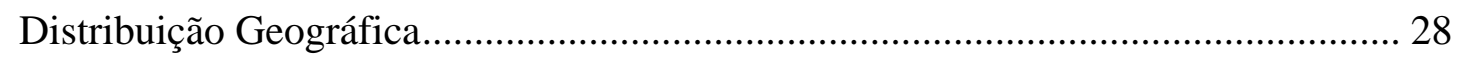

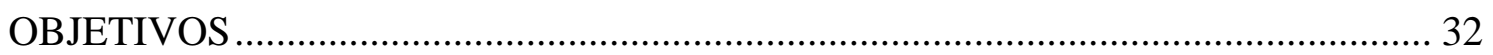

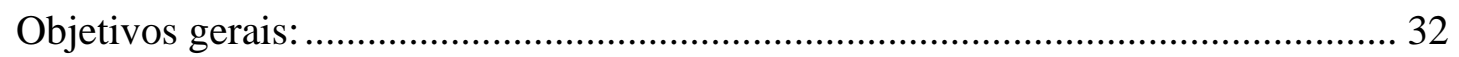

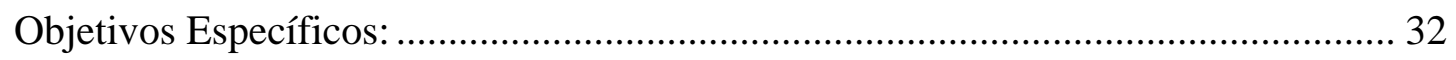

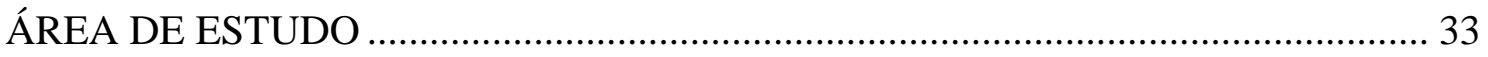

Característica Físicas ........................................................................................ 33

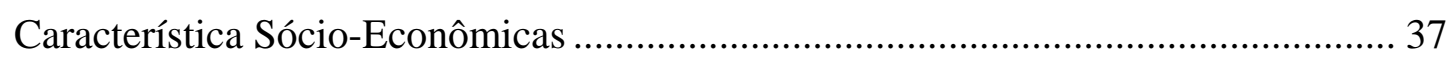

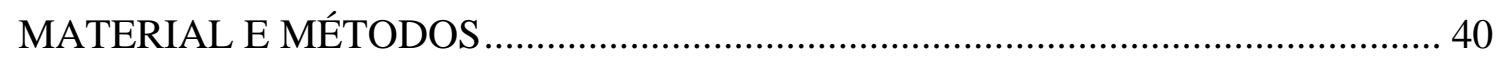

1. Compreender o padrão de distribuição dos grânulos plásticos nas praias da Enseada

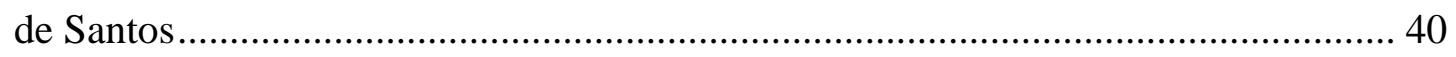

1.1 Avaliar a distribuição dos grânulos em profundidade no sedimento................ 40

1.2 Avaliar a distribuição dos grânulos ao largo da praia (distribuição vertical)... 41

1.3 Avaliar a distribuição dos grânulos ao longo da praia (distribuição horizontal)

2. Calcular a taxa de entrada dos grânulos ............................................................. 45

3. Descrever as características dos grânulos........................................................... 46 


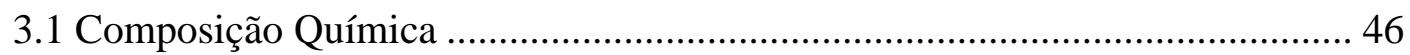

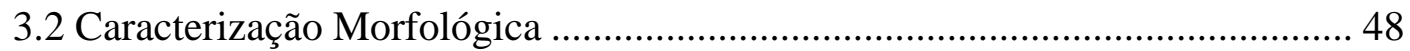

4. Identificar as possíveis fontes de emissão de grânulos para a Enseada de Santos . 50 RESULTADOS 52

1. Compreender o padrão de distribuição dos grânulos plásticos nas praias da Enseada de Santos 52

1.1 Avaliar a distribuição dos grânulos em profundidade no sedimento. 52

1.2 Avaliar a distribuição dos grânulos ao largo da praia (distribuição vertical)... 53

1.3 Avaliar a distribuição dos grânulos ao longo da praia (distribuição horizontal) 54

2. Calcular a taxa de entrada dos grânulos nesta área 58

3. Descrever a característica dos grânulos 60

3.1 Composição Química 60

3.2 Caracterização morfológica em relação à profundidade no sedimento 62

3.3 Caracterização morfológica em relação à área e período de coleta na linha de deixa e estação do ano 73

4. Identificar as possíveis fontes de emissão de grânulos para a Enseada de Santos. 80 DISCUSSÃO 86

1. Compreender o padrão de distribuição dos grânulos plásticos nas praias da Enseada de Santos 86

2. Calcular a taxa de entrada dos grânulos nesta área 91

3. Descrever as características dos grânulos.............................................................. 93

3.1 Composição Química ..................................................................................... 93

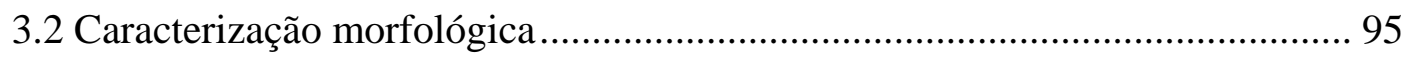

4. Identificar as possíveis fontes de emissão de grânulos para a Enseada de Santos . 99

5. Controle e Gestão 104 
ANEXOS

Anexo I. Perfil praial (desnível) nas áreas de coleta para análise da variação do número de pellets ao longo da Enseada de Santos. Distância a partir do calçadão.. 122 


\section{Lista de Figuras}

Figura 1. "Plastic Pellets” coletados em Santos. (Fonte: A. Turra; Escala: 5 mm)........ 17

Figura 2. Região Metropolitana da Baixada Santista. (Fonte: Google Maps)................ 33

Figura 3. Enseada e Estuário de Santos e São Vicente. Os canais de Santos (1 a 7) estão evidenciados em cor vermelha e as praias amostradas em cor amarela (aquelas pertencentes aos respectivos municípios estão separadas pelo emissário submarino).

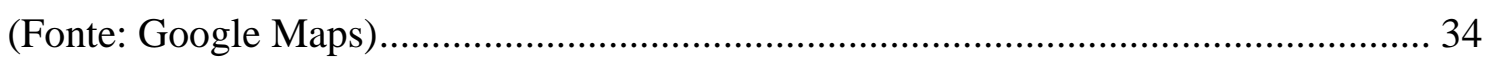

Figura 4. Visão parcial do Porto e Enseada de Santos. Imagem do Google Earth......... 38

Figura 5. Coleta para amostragem da distribuição dos grânulos em profundidade no sedimento.

Figura 6. Procedimentos de coleta para avaliar a distribuição ao largo (vertical) da Enseada de Santos utilizando uma cavadeira tipo trado de 6’ de diâmetro 42

Figura 7. Áreas de coleta para amostragem da distribuição dos grânulos ao longo da praia (distribuição horizontal).

Figura 8. Áreas de coleta para amostragem da taxa de entrada dos grânulos. 46

Figura 9. Esquema de separação de polímeros por diferença de densidades. PEBD (Polietileno de Baixa Densidade), PEAD (Polietileno de Alta Densidade), PP (Polipropileno), PS (Poliestireno) e PVC (Policloreto de Vinilideno). (Fonte: Spinacé e De Paoli, 2005) 47

Figura 10. Espectro padrão de polipropileno (PP). 48

Figura 11. Espectro padrão de polietileno (PE). 48

Figura 12. Formas de pellets observados nas praias da Enseada de Santos. a.esférica achatada, b.cilíndrica, c.cilíndrica achatada, d.cúbica, e. esférica, f.retangular, g./h.retangular achatada, i.disforme.

Figura 13. Principais padrões de cores dos pellets coletados nas praias da Enseada de Santos, em RGB (a.30; b.29; c.28; d.25; e.32; f.41; g.204; h.218; i.0). 50

Figura 14. Média e erro padrão do total de pellets por $0.1 \mathrm{~m}^{3}$ a cada intervalo de $10 \mathrm{~cm}$ de profundidade no sedimento $(\mathrm{n}=10)$. 52 
Figura 15. Média e erro padrão do total de pellets por $0,018 \mathrm{~m}^{3}$ a cada intervalo de $6,5 \mathrm{~m}$ ao largo da praia $(n=25)$ em relação à variação do perfil (desnível, cm). As letras sobrescritas representam o resultado do teste SNK (letras idênticas representam diferenças não significativas). 53

Figura 16. Média e erro padrão do número de pellets por $0,036 \mathrm{~m}^{3}$ a cada área da amostragem ao longo da praia $(n=3)$. As letras sobrescritas representam o resultado do teste SNK (letras idênticas representam diferenças não significativas). 55

Figura 17. Média e erro padrão do número de pellets por ST (ST - "Strip Transect"/Transecto Linear) a cada área da amostragem ao longo da praia. As letras sobrescritas representam o resultado do teste SNK (letras idênticas representam diferenças não significativas). 55

Figura 18. Média do número de pellets por $1 \mathrm{~m}^{3}$ na coluna de sedimento (0 a $2.0 \mathrm{~m}$ ) em relação às distâncias ao longo (15 áreas) e ao largo da praia (0 a 120m). Os pontos realçam as amostras eqüidistantes realizadas em cada área. 56

Figura 19. Número de pellets por $1 \mathrm{~m}^{3}$ em cinco classes de profundidade no sedimento (respectivamente, de cima para baixo: 0-0,4;0,4-0,8;0,8-1,2;1,2-1,6;1,6-2,0) em relação às distâncias ao largo $(n=10)$ e ao longo da praia $(n=15)$. 57

Figura 20. Média e erro padrão do total de pellets por $\mathrm{m}^{2}$ encontrados na linha de deixa nos 3 períodos de coleta realizados para cada uma das 6 áreas amostrados ao longo das estações do ano. 59

Figura 21. Espectro de uma das amostras de polietileno (PE). 61

Figura 22. Espectro de uma das amostras de polipropileno (PP).

Figura 23. Espectro de uma das amostras consideradas como mistura de polietileno (PE) e polipropileno (PE).

Figura 24. Média e erro padrão da altura dos pellets a cada intervalo de $10 \mathrm{~cm}$ de profundidade no sedimento nas praias da Enseada de Santos. As letras sobrescritas representam o resultado do teste SNK (letras idênticas representam diferenças não significativas).

Figura 25. Distribuição de freqüência da altura dos pellets em intervalos de profundidade de $10 \mathrm{~cm}$ no sedimento ( $\mathrm{n}=$ número de pellets analisados, $\mathrm{X}=$ média \pm desvio padrão). 
Figura 26. Média e erro padrão do diâmetro dos pellets a cada intervalo de $10 \mathrm{~cm}$ de profundidade no sedimento nas praias da Enseada de Santos. As letras sobrescritas representam o resultado do teste SNK (letras idênticas representam diferenças não significativas).

Figura 27. Distribuição de freqüência do diâmetro dos pellets em intervalos de profundidade de $10 \mathrm{~cm}$ no sedimento ( $\mathrm{n}=$ número de pellets analisados, $\mathrm{X}=$ média \pm desvio padrão). 66

Figura 28. Porcentagem de pellets para cada formato analisado por profundidade amostrada. 68

Figura 29. Porcentagem de pellets classificados por padrões de cores em RGB. 69

Figura 30. Porcentagem de pellets em cada intervalo de $20 \%$ de incrustação por intervalo de profundidade. 70

Figura 31. Porcentagem de pellets em cada intervalo de $20 \%$ de rebarba por intervalo de profundidade.

Figura 32. Porcentagem de pellets em cada intervalo de $20 \%$ de craquelamento por intervalo de profundidade.

Figura 33. Média e erro padrão da altura dos pellets coletados na linha de deixa em diferentes áreas e estações do ano.

Figura 34. Média e erro padrão do diâmetro dos pellets coletados na linha de deixa em diferentes áreas e estações do ano. 74

Figura 35. Dispersão dos pellets no $1^{\circ}$, $8^{\circ}$ e $12^{\circ}$ mês relativos aos pontos 1 e 2 (respectivamente à coluna esquerda e direita) como possíveis fontes de emissão.

Figura 36. Dispersão dos pellets no $1^{\circ}, 8^{\circ}$ e $12^{\circ}$ mês relativos aos pontos 3 e 4 (respectivamente à coluna esquerda e direita) como possíveis fontes de emissão. 84

Figura 37. Dispersão dos pellets no $1^{\circ}, 8^{\circ}$ e $12^{\circ}$ mês relativos aos pontos 5 e 6 (respectivamente à coluna esquerda e direita) como possíveis fontes de emissão. 85 


\section{Lista de Tabelas}

Tabela 1. Principais polímeros e suas propriedades e usos: Polietileno de Alta Densidade (PEAD), Polietileno de Baixa Densidade (PEBD), Polipropileno (PP) Poliestireno (PS) e Policloreto de Vinila (PVC). (Fonte: Sociedade das Indústrias

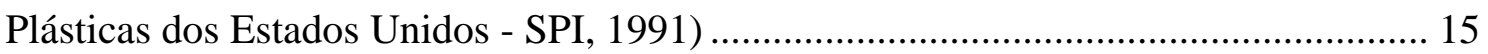

Tabela 2. Datas das coletas para análise da taxa de entrada dos pellets........................46

Tabela 3. Análise de variância do tipo I de três fatores para analisar a variação na quantidade de pellets em função da estação do ano, período de coleta e área amostrada.

Tabela 4. Comparação entre os métodos de densidade e Microscopia Ramam na análise da composição química de 500 pellets. Os polímeros encontrados foram Polipropileno (PP), Polietileno de Alta Densidade (PEAD), Polietileno de Baixa Densidade (PEBD) e mistura de PP e PE.

Tabela 5. Análise de variância do tipo I de dois fatores para analisar a variação na altura dos pellets coletados na linha de deixa entre áreas de coleta e estações do ano. 74

Tabela 6. Análise de variância do tipo I de dois fatores para analisar a variação no diâmetro dos pellets coletados na linha de deixa entre áreas de coleta e estações do ano.

Tabela 7. Porcentagem de pellets para cada formato analisado, de acordo com as áreas e as estações do ano (formas: Cilíndrico, Cilíndrico-achatado, Esférico, Esféricoachatado, Retangular, Cúbica e Disforme). Os valores de qui-quadrado referem-se às comparações entre áreas dentro de cada estação do ano. 76

Tabela 8. Porcentagem de pellets classificados por padrões de cor em RGB nas 6 áreas de coleta para cada estação do ano. Algumas cores não estão representadas por apresentarem, de uma forma geral, os menores índices. Ver Figura 29 para legenda de cores

Tabela 9. Porcentagem de pellets em cada intervalo de 20\% de Incrustação, Rebarba e Craquelamento nas 6 áreas de coleta em cada estação do ano. 


\section{AGRADECIMENTOS}

Dedico a execução desta pesquisa a muitas destas pessoas, que fizeram e que ainda fazem parte dos meus breves momentos:

- a meus pais, eternos e vigorosos apoiadores em todas as minhas decisões tão indecisas. O apoio de vocês sempre foi e para sempre será crucial na escolha de cada passo além (ou às vezes até aquém!);

- aos amigos, que nas horas mais difíceis reacendiam a chama da vela que estava próxima a apagar. Mesmo àqueles que não conseguiram participar de forma ativa no desenvolvimento do estudo, estavam sempre dispostos a ouvir minhas lamentações e angústias e ajudar a esquecê-las, mesmo que por breves momentos, em baladas (Sheylla e Diogo) ou numa mesa de bar (Janaína);

- à todos que me auxiliaram nas árduas e incansáveis coletas de campo: técnicos do IO, meninas do LabManejo (Giuliana, Priscilla, Luciana, Maíra), em especial à Thayana e Juliana, companheiras leais sem as quais provavelmente a finalização do trabalho não aconteceria a tempo;

- aos professores colaboradores, Eduardo Siegle e Joseph Harari, com as informações na área da Oceanografia Física, conhecimento ausente na minha formação de Bióloga, à Denise Petri e Koiti Akari, com as análises químicas;

- ao CNPq pela bolsa de estudos durante o curso de mestrado;

- à todos que de alguma maneira auxiliaram no andamento da pesquisas, como o Lucas e a Camila, pelas análises em laboratório;

- à uma pessoa especial que surgiu na minha 'nova vida' de forma tão inesperada que, desta mesma maneira, despertou minha admiração e paixão eternas. Você apareceu no momento em que eu mais precisaria de alguém. Além do apoio, sua alegria e positividade me deram forças para continuar e conseguir alcançar a reta final, a fase mais difícil de todas. Amor eterno!;

- e, por fim, ao meu orientador, Alexander Turra, primeiramente pela oportunidade de desenvolver um projeto de pesquisa na área em que sempre tive interesse, e pela confiança, motivação e paciência ao longo destes 3 anos.

Muitas pessoas passaram pela minha vida ao longo do desenvolvimento desta pesquisa. Pessoas que já faziam parte dela e outras que apareceram de forma tão inesperada e tão maravilhosa. Nestes 3 anos aprendi que não necessariamente devemos manter contato com todos que de alguma forma interferiram em nossas vidas, mas sim 
que, no momento certo, e por um tempo certo, elas vieram e se foram, deixando lembranças que jamais serão esquecidas. É por esses breves momentos que percebemos que a vida vale a pena! 


\section{RESUMO}

Dentre os vários poluentes que ameaçam o ambiente marinho estão os pellets de plástico, matéria prima em forma de grânulos de $5 \mathrm{~mm}$ que estão sendo liberados nas etapas de produção, utilização e transporte. Este projeto visa o entendimento da contaminação das praias da Enseada de Santos, litoral do Estado de São Paulo, como uma área piloto para se compreender os padrões de distribuição e identificar a composição química e taxa de entrada. Os pellets foram encontrados a até $2 \mathrm{~m}$ de profundidade, mas se concentraram na porção mais superior do sedimento (com cerca de 1.100 pellets por $0,1 \mathrm{~m}^{3}$ nos $30 \mathrm{~cm}$ superiores) e na região do pós-praia (136 pellets $/ 0.018 \mathrm{~m}^{3}$ na porção mais elevada). A distribuição ao longo da praia mostrou que os pellets se concentraram nas áreas mais próximas ao Canal de Santos, com uma taxa média de 82 pellets $/ 0.036 \mathrm{~m}^{3}$, e chegando à densidade máxima de $139 / 0.036 \mathrm{~m}^{3}$, fato relacionado principalmente com a circulação da Baía e correntes provenientes do Canal. A taxa de entrada não mostrou um padrão ao longo da baía e períodos do ano, mas o maior número de pellets foi encontrado no Inverno $\left(377 / \mathrm{m}^{2}\right)$, após um evento de tempestade. Quase 80\% eram Polietileno e cerca de 20\% Polipropileno; o tamanho médio foi cerca de 2.5 a 3.0mm de altura e 3.5 a $4.0 \mathrm{~mm}$ de diâmetro; e quase $70 \%$ tinha coloração clara à amarelada. A maior parte dos pellets analisados apresentou-se relativamente preservada. As prováveis fontes de emissão (porto e indústrias) estão localizadas na região estuarina.

Palavras-chaves: resíduos sólidos, poluentes, pellets, Santos, distribuição, composição, emissão. 


\begin{abstract}
Among the various pollutants that threaten the ocean are plastic pellets, prime resource in the form of $5 \mathrm{~mm}$ granules that are being dumped in the environment during production, utilization and transport stages. This project aims to understand of the contamination of the beaches of the Santos Bay, coast of the state of São Paulo, as a pilot area to address the patterns of distribution and identify the chemical composition and rate of entry of pellets. The pellets were found even at $2 \mathrm{~m}$ depths, but were concentrated at the upper level of sediment (with approximately 1100 pellets per $0.1 \mathrm{~m}^{3}$ on the top) and in the back-shore region (136 pellets $/ 0.018 \mathrm{~m}^{3}$ at the higher level). The distribution along the beach showed that the pellets were concentrated in the areas closer to the Santos estuarine Channel, with an average rate of 82 pellets $/ 0.036 \mathrm{~m}^{3}$, and reaching a maximum density of $139 / 0.036 \mathrm{~m}^{3}$, a fact directly related to the circulation of the bay and channel currents. The rate of entry did not show a pattern along the bay and periods of the year, but the greatest number of pellets were found during the winter after a storm $\left(377 / \mathrm{m}^{2}\right)$. Almost $80 \%$ were polipropilene and about $20 \%$ poliethylene. The average size was circa 2.5 to $3.0 \mathrm{~mm}$ in length and 3.5 to $4.0 \mathrm{~mm}$ in diameter and almost $70 \%$ were clear colored or yellowish. The greatest part of the analyzed pellets appeared relatively preserved. The probable sources of emission (harbor and industries) are located in the estuarine region.
\end{abstract}

Key-words: solid wastes, pollutants, pellets, Santos, distribution, composition, emission. 


\section{INTRODUÇÃO}

\section{Plásticos no mundo: importância, características e produção}

Existe atualmente uma extrema preocupação mundial com o ambiente aquático, em especial com o marinho, pois compreende uma grande parcela do planeta e sua importância no ciclo global já está amplamente definida e difundida. Durante muito tempo acreditou-se que os oceanos seriam capazes de se recuperar diante de todos os impactos que a ação humana lhes causaria. Mas agora, diante de uma série de fenômenos recentes e inesperados, alertas estão surgindo para mostrar a real situação dos oceanos, que pode ter ultrapassado sua capacidade de auto-regeneração.

Dentre as inúmeras causas para os problemas ambientais nos oceanos está a grande quantidade de resíduos da atividade humana que nele chegam, como os resíduos sólidos (ver Derraik, 2002, para uma revisão recente). Os resíduos marinhos são definidos como "qualquer material sólido descartado manufaturado ou processado (tipicamente inerte) que entra no ambiente marinho por diversas fontes” (Coe e Rogers, 1997). Uma das preocupações está relacionada com a quantidade e tipos destes resíduos nas praias e oceanos, problema que ganhou uma ampla preocupação pública nas últimas décadas. Os resíduos marinhos têm impactos econômicos, estéticos e ecológicos (Furness, 1985a; Fry et al., 1987; Laist, 1987; Nash, 1992; Mato et al., 2001; Ananthaswamy, 2001; Ericksson e Burton, 2003; Masó et al., 2003; Endo et al., 2005; Williams et al., 2005) e podem ser de origem tanto terrestre, através de descartes em locais impróprios por turistas e de sistemas de drenagem de rios e águas pluviais, quanto aquática, por despejos diretos nos oceanos e mares principalmente por embarcações e atividades portuárias (EPA, 1992a; Williams et al., 2005).

Um dos itens de particular preocupação são os plásticos, com diversos registros de pesquisas demonstrando sua dominância dentre os tipos de poluentes no ambiente marinho e costeiro (Wilber, 1987; Gilligan et al., 1992; Garrity e Levings, 1993; Jones, 1995; Coe e Rogers, 1997; Bowman et al., 1998; Derraik, 2002; Kusui e Noda, 2003; McDermid e McMullen, 2004; Santos et al., 2009).

Os plásticos estão presentes por toda parte na sociedade moderna e seu uso vem se acentuando. Nas últimas décadas foi um dos materiais que mais se desenvolveu e aumentou de produção (Lima, 2001). Utilizamos os produtos plásticos para beber, comer, sentar e até para nos locomover (Moore, 2002). Eles são duráveis, leves, baratos 
e podem ser transformados em produtos de várias formas e tamanhos (Pruter, 1987; Wilber, 1987; Moore, 2002). O termo 'plástico’ vem do grego plastikus, que significa ‘adequado à moldagem’. A produção de plásticos e seu uso têm aumentado em demasia devido a várias vantagens que esse material apresenta em relação aos demais: i. flexibilidade para ser moldado em uma grande variedade de formas; ii. alta resistência à corrosão; iii. baixo peso; iv. resistência à impactos mecânicos; v. resistência à água; vi. impermeabilidade ao ar (Gordon, 2006).

Todo ser humano usa direta e indiretamente materiais de plástico todo dia. De acordo com Watson (2001), os bebês começam sua vida usando cerca de 100 milhões de kg de fraldas plásticas todo ano, além de mamadeiras e brinquedos de plástico. Compramos suas comidas em recipientes de plásticos, pagando com um cartão de crédito de plástico. Cada pessoa usa em média 100kg de plástico anualmente na forma de garrafas de água, embalagens de fast food, móveis, seringas, computadores, materiais de embalagens, sacos de lixo entre outros, totalizando uma estimativa de cerca de 60 bilhões de toneladas de material plástico produzidos mundialmente por ano (Watson, 2001).

A maior parte dos materiais plásticos não existia antes dos anos 30. Na segunda metade do século XIX desenvolveu-se o celulóide, um material plástico baseado em celulose modificada de material natural que era produzido da madeira ou palha (Lima, 2001). Em seguida novos compostos surgiram para explorar as características deste produto, como a resina de acetato de celulose. Entre 1900 e 1940 muitos progressos científicos e tecnológicos foram alcançados. Em 1907 o primeiro termorrígido, a baquelite, foi patenteado e a $1^{\text {a }}$ Guerra Mundial estimulou o desenvolvimento de materiais como o Policloreto de Vinila (PVC) na Alemanha (Lima, 2001). No começo dos anos 30 foram desenvolvidas a estrutura e síntese das substâncias chamadas de materiais poliméricos (Lima, 2001). São considerados polímeros as moléculas relativamente grandes, de peso molecular da ordem de 103 a 106 cuja estrutura é composta de unidades químicas repetidas, os monômeros (Mano, 1999).

A matéria-prima do plástico é derivada do petróleo ou do gás natural, que é formado por uma complexa mistura de compostos. Pelo fato destes compostos possuírem diferentes temperaturas de ebulição é possível separá-los em misturas ou cortes através de colunas de destilação. Um desses cortes, a nafta, é fornecida para as centrais petroquímicas, onde passa por uma série de processos, dando origem aos principais monômeros, como por exemplo, o eteno. 
Os pellets mais comuns são derivados do Propileno, como o Polipropileno (PP), o Polietileno (PE) e o Poliestireno (PS)(Shiber, 1982 e 1987; Pruter, 1987; EPA, 1992a). Estes compostos são também as resinas mais utilizadas pelas indústrias (Pruter, 1987; EPA, 1992a). A grande variedade de produtos de plásticos produzidos internacionalmente tem criado uma demanda por diferentes tipos de resinas ou por suas combinações. Combinando polímeros, criando novos ou incorporando aditivos, as resinas podem ser feitas sob medida de acordo com a aplicação desejada e o produto final (EPA, 1990a).

Existem dois principais tipos de resinas, que são classificadas de acordo com as características de fusibilidade (Mano, 1999): as resinas termoplásticas e as resinas termorrígidas. As primeiras podem ser derretidas ou reprocessadas sem danificar ou alterar as propriedades químicas e físicas do polímero; são altamente maleáveis mas tornam-se rígidas quando esfriadas. Devido à estreita faixa entre o ponto de derretimento da resina termoplástica e a temperatura na qual a resina irá se decompor, estas resinas são mantidas no estado líquido (derretidas) por um tempo mínimo e são pelletizadas assim que possível (EPA, 1990a). Os polímeros termoplásticos mais comumente usados são o Polietileno de Baixa Densidade (PEBD), Policloreto de Vinila (PVC), Polietileno de Alta Densidade (PEAD), o Polipropileno (PP) e o Poliestireno (PS)(EPA, 1990a). Os principais polímeros e suas propriedades e usos estão apresentados na tabela 1 .

Em contraste, as resinas termorrígidas são mais resistentes quando expostas a altas temperaturas; tendem a ser rígidas, infusíveis e insolúveis, e não podem ser refundidas e remoldadas. Geralmente são transportadas aos processadores na forma líquida, onde são tratadas e moldadas (EPA, 1990a). Dentre as resinas termorrígidas, as mais comumente utilizadas incluem as resinas fenólicas e o Poliuretano (Lima, 2001). Geralmente estas resinas são empregadas em materiais de construção e partes automotivas (EPA, 1990a). 
Tabela 1. Principais polímeros e suas propriedades e usos: Polietileno de Alta Densidade (PEAD), Polietileno de Baixa Densidade (PEBD), Polipropileno (PP) Poliestireno (PS) e Policloreto de Vinila (PVC). (Fonte: Sociedade das Indústrias Plásticas dos Estados Unidos SPI, 1991)

\begin{tabular}{|c|c|c|}
\hline Polímero & Propriedade & Uso \\
\hline PEAD & $\begin{array}{l}\text { - Rígido; } \\
\text { - Resistência química e à umidade; } \\
\text { - Permeabilidade gasosa; } \\
\text { - Translúcido ou opaco; } \\
\text { - Flutua na água. }\end{array}$ & $\begin{array}{l}\text { - Embalagens de leite, água e suco; } \\
\text { - Saco de lixo e de mercado; } \\
\text { - Embalagens de detergente; } \\
\text { - Tubos de iogurte e margarina; } \\
\text { - Revestimento de caixas de cereal. }\end{array}$ \\
\hline PEBD & $\begin{array}{l}\text { - Rígido; } \\
\text { - Leve; } \\
\text { - Barreira à umidade; } \\
\text { - Próximo ao transparente ou opaco; } \\
\text { - Pouco ou muito brilho; } \\
\text { - Flutua na água. }\end{array}$ & $\begin{array}{l}\text { - Sacos de pão e congelados; } \\
\text { - Garrafas squeeze; } \\
\text { - Fibras; } \\
\text { - Frascos; } \\
\text { - Roupas; } \\
\text { - Móveis e carpete. }\end{array}$ \\
\hline PP & $\begin{array}{l}\text { - Rígido, resistência química e ao calor; } \\
\text { - Barreira à umidade; } \\
\text { - Resistência à graxa/óleo; } \\
\text { - Flutua na água. }\end{array}$ & $\begin{array}{l}\text { - Embalagem de ketchup; } \\
\text { - Iogurte e tubos de margarina. }\end{array}$ \\
\hline PS & $\begin{array}{l}\text { - Rígido; } \\
\text { - Translúcido ou opaco; } \\
\text { - Superfície macia; } \\
\text { - Afunda na água. }\end{array}$ & $\begin{array}{l}\text { - Botões; } \\
\text { - Frascos de aspirina. }\end{array}$ \\
\hline PVC & $\begin{array}{l}\text { - Rígido; } \\
\text { - Transparente, translúcido ou opaco; } \\
\text { - Resistência química e à graxa/óleo; } \\
\text { - Afunda na água. }\end{array}$ & $\begin{array}{l}\text { - Embalagens de alimento e de } \\
\text { shampoo; } \\
\text { - Suprimentos para entubação } \\
\text { médica e frascos de remédio; } \\
\text { - Isolamento de fios e cabos. }\end{array}$ \\
\hline
\end{tabular}

Algumas resinas são usadas na sua forma pura, mas, mais freqüentemente, as propriedades do polímero precisam ser mudadas para confeccionar o produto final desejado (EPA, 1992a). Aditivos são usados para alterar as características físicas do polímero, tais como as propriedades estéticas (cor e forma), físicas (resistência térmica e dureza) e a habilidade de ser posteriormente processado (por ex., porosidade)(EPA, 1990a).

O tipo do aditivo determina quando e como ele será aplicado ao polímero. Dois métodos são usados para incorporá-los: (1) ele (sólido ou líquido) é misturado ou (2) reage quimicamente com o polímero (eles são unidos/ligados)(EPA, 1992a). Nas discussões ecológicas, esta distinção é muito importante quando se considera a lixiviação dos aditivos no ambiente e seus potenciais efeitos toxicológicos. Os aditivos fisicamente misturados com o polímero podem estar mais propensos à lixiviar porque o aditivo não está quimicamente ligado ao polímero. A lixiviação pode ser determinada 
pela miscibilidade (habilidade de ser misturado) do aditivo e do polímero e pelas condições ambientais (temperatura). Aditivos incorporados através de reações químicas não são lixiviados do plástico, a menos que o plástico seja quebrado quimicamente (EPA, 1990a).

Uma estimativa de 30 milhões de toneladas de resina eram produzidos anualmente no início dos anos 90 nos EUA, muito dos quais foram “pelletizados” (EPA, 1992a). Se cada tonelada de PEAD pelletizado contém aproximadamente 44.000.000 pellets (de acordo com a Sociedade das Indústrias Plásticas - SPI, 1991), e esta estimativa puder ser extrapolada à todas as outras resinas, então mais do que 1 quadrilhão de pellets pode ser produzido anualmente só nos EUA.

Em 2008 o setor de transformação no Brasil processou 5,1 milhões de ton de resinas (dos quais 4,8 milhões foram produzidas) e produziu mais de 5 mil ton de transformados termoplásticos ${ }^{1}$. Devido às propriedades dos plásticos, o consumo de polímeros vêm crescendo em todo o mundo, e no Brasil não é diferente. Segundo a ABIQUIM (Associação Brasileira da Indústria Química), em 2008 foram produzidos cerca de 2 milhões ton de PEBD e 1.772 mil ton de PEAD; a produção de PET, PP, PS e PVC foi de 800, 1.425, 635 e 786 mil ton, respectivamente ${ }^{1}$. Apesar da ampla variedade de termoplásticos, apenas estes cinco polímeros (PE, PP, PVC, PET e PS) representam cerca de $90 \%$ do consumo nacional ${ }^{2}$. O consumo de transformados plásticos foi de mais de 5 milhões de ton em 2008. Em 2008, eles foram utilizados principalmente nos setores alimentícios (17,5\%), construção civil (15,6\%), embalagens (14,5\%), utilidades domésticas (9,3\%), agrícola (10,6\%) e outros $(14,8 \%)^{1}$.

Os dados de exportação/importação também são significativos. Segundo dados da Abiplast (Associaçao Brasileira da Indústria do Plástico), o Brasil exportou 817 mil ton de polímeros (correspondendo a US\$ 729 milhões) e importou 544 mil ton (US\$ 626 milhões) ${ }^{1}$.

Portanto, "Plastic Pellets” (Figura 1) são grânulos de plásticos que correspondem à forma principal com que as resinas plásticas são produzidas e comercializadas para serem usadas como matéria prima em indústrias de transformação para a criação dos mais variados objetos, produzidos após estas serem derretidas e

\footnotetext{
${ }^{1}$ www.abiplast.org.br

${ }^{2}$ www.plasticoonline.com.br
} 
moldadas de acordo com o produto final. Os pellets podem ser produzidos de várias formas (esféricas, ovóides e cilíndricas), tamanhos (de 1 a 5mm) e cores (geralmente claras, brancas ou transparentes), dependendo de sua composição química e de seu propósito final. As resinas também podem ser produzidas em outras formas de fácil transporte, como flocos ou em pó (Wilber, 1987; EPA, 1990a).

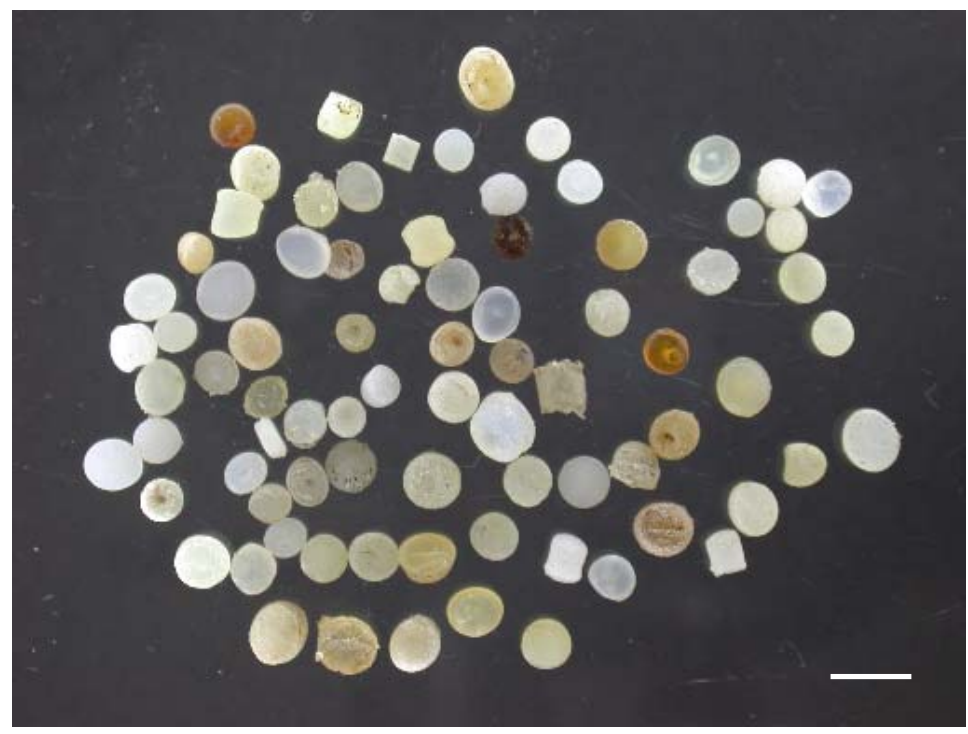

Figura 1. "Plastic Pellets” coletados em Santos. (Fonte: A. Turra; Escala: 5 mm)

\section{Impactos: Estéticos, Econômicos e Ecológicos}

Há décadas os ambientalistas apontam que os materiais plásticos descartados no mar representam uma das maiores ameaças ao meio ambiente. Cerca de $90 \%$ do lixo nos oceanos é composto de plástico (Galgani et al., 1995a, b; Coe e Rogers, 1997; Derraik, 2002). O Programa Ambiental das Nações Unidas estima que cerca de 18.400 partículas plásticas flutuam em cada $\mathrm{km}^{2}$ dos oceanos (Watson, 2001). Desse total, quatro quintos chegam até o mar varridos pelo vento ou levados pela água da chuva, esgotos e rios, enquanto um quinto é lançado pelos navios. Devido à pequena taxa de degradação, o plástico permanece no ecossistema marinho por longo período, evidenciando um grande volume de lixo que foi se acumulando desde a metade do século XX (Watson, 2001).

As regiões litorâneas têm sido submetidas a freqüentes impactos ambientais, tanto de origem urbana quanto industrial. A intensa urbanização e industrialização da zona costeira vêm ocorrendo sem um correto planejamento ambiental, resultando em 
várias fontes de emissão de poluentes para o ar, solo e água. Este ambiente está sendo contaminado por poluentes (orgânicos, químicos e/ou tóxicos) transportados por águas residuais oriundas de descartes domésticos (banho, cozinha e lavagens em geral), industriais (resultante dos processos de fabricação) e urbanos (chuvas e lavagem de pavimentos) ${ }^{3}$. Assim é recomendável o tratamento de $100 \%$ dessa água antes de atingir novamente os recursos hídricos, o que infelizmente não ocorre com freqüência de forma que muitos poluentes têm o seu fim no ambiente marinho, como os plásticos, por exemplo.

Além disso, a abundância de produtos plásticos constitui uma grande porção, especialmente no volume, dos resíduos sólidos urbanos coletados no mundo (Lima, 2001). No Brasil, o destino principal desses resíduos tem sido aterros, corpos d’água ou ainda a incineração, processos que dispersam poluentes não-biodegradáveis cujas partículas podem alcançar o ambiente marinho (Watson, 2001). Em 1996, os principais polímeros encontrados nos resíduos sólidos urbanos de grandes cidades brasileiras foram o PEAD e PEBD (quase 35\%), PET (20\%), PVC (20\%) e PP (10\%)(Agnelli, 1996). Em regiões portuárias há ainda o problema do acúmulo de rejeitos plásticos que, inevitavelmente, alcançam os oceanos. Esses resíduos são gerados tanto pelo comércio e serviços como pelas indústrias, principalmente por refugos, como peças fora de especificação técnica, aparas e rebarbas do processo (Lima, 2001). Outra fonte provém dos descartes por consumidores finais, mas esta constitui menos de $30 \%$ do total de plástico lançado nos oceanos todo ano (Watson, 2001). A maior parte da poluição marinha é originada por perdas de materiais de embarcações (pesqueiras, petroleiros, cargueiros, etc.) e ainda por rios e tubulações de saída das drenagens municipais de água de chuva (Moore et al., 2002) que, associados a correntes marítimas e eventos de tempestade, podem alcançar regiões a grandes distâncias da costa (Moore e Allen, 2000).

Infelizmente todo esse material não desaparece no ambiente, apenas dos olhos da sociedade. As correntes oceânicas mantêm os resíduos sólidos em constante circulação, que são posteriormente concentrados por correntes e ondas em frentes oceânicas convergentes (Carr, 1987), chamadas de giros ou vórtices. Um dos maiores

\footnotetext{
${ }^{3}$ http://www.cetesb.sp.gov.br
} 
destes movimentos é o Giro Central do Atlântico, que se concentra fortemente no norte do Mar de Sargasso e se move num padrão circular dirigido pela Corrente do Golfo. Charles Moore, em uma de suas expedições ao Giro Central do Pacífico, em 2002, área conhecida como o "Grande Remendo de Lixo do Pacífico" onde há o acúmulo de resíduo plástico flutuante, detectou níveis muito altos de fragmentos em centenas de quilômetros. Os fotógrafos capturaram imagens de águas vivas enredadas em linhas e de organismos filtradores transparentes com fragmentos de plásticos coloridos no seu interior; além de ter sido documentada também uma Corrente de Langmuir de entulhos de plástico (correntes oceânicas com a rotação contrária que criam longas linhas de material, visíveis de cima como listras no oceano, mas que normalmente são formadas por organismos planctônicos ou espuma)(Moore, 2002).

Soma-se a essas estimativas o fato do tempo de permanência deste material ser muito variável e dependente de diversos fatores específicos de cada local (Karapanagioti e Klontza, 2007). Especialistas em deterioração de plástico afirmaram que eles podem durar centenas de anos, pois possuem como características a resistência a radiações, calor, ar e água. Mas são justamente estas propriedades úteis que fazem dos plásticos tão nocivos quando descartados no ambiente (Moore, 2002).

O impacto do crescente acúmulo de plástico nos oceanos é tido como mais grave do que todos os derrames anuais de óleo do mundo (Watson, 2001). Derramamentos de óleo ocorrem todo dia nos oceanos e os maiores ocorrem em média a cada duas semanas em algum lugar do ecossistema marinho. Embora sejam notoriamente degradantes à vida marinha, seu impacto é confinado a áreas geográficas relativamente pequenas e reduz-se com o tempo. O derramamento do Exxon Valdez, por exemplo, foi restrito a uma pequena região do Alaska e, embora o impacto sobre a vida selvagem fora sentida por muitos anos, o ecossistema está em recuperação (Watson, 2001). Já a contaminação por plásticos é de certa forma permanente e, portanto, cumulativa.

Diversos danos econômicos derivados dos resíduos plásticos no ambiente marinho foram levantados e estão principalmente relacionados com problemas nos hélices de embarcações e sistemas de utilização de água do mar (Gordon, 2006). Além do desperdício financeiro por perda de matéria-prima (Pianowski, 1997), o ingresso dos plásticos nos sistemas de resfriamento de motores de embarcações causa prejuízos anuais da ordem de 50 milhões de dólares no Japão (Watson, 2001). Em algumas regiões ainda foi observado o impacto no turismo devido à presença massiva de 
resíduos sólidos em praias, podendo acarretar grandes prejuízos para a economia local (EPA, 1990b; Abu-Hilal e Al-Najjar, 2004; Gordon, 2006).

Resíduos plásticos são de particular preocupação também porque não são biodegradáveis, e sim "fotodegradáveis", um processo no qual suas partículas quebramse em tamanhos cada vez menores pela ação do sol (Kanehiro et al., 1995; Watson, 2001; Gordon, 2006) e podem, ao serem erodidos pelo mar, se transformar em pequenos grânulos semelhantes aos pellets industrializados, tanto morfologicamente (Pruter, 1987) quanto em relação ao comportamento no ambiente (Costa et al., 2009). Estes materiais, como redes e linhas de pesca perdidas ou descartadas, cordas, fios de nylon, fitas resistentes para amarrar embalagens e itens domésticos como sacos de lixo, forros e braçadeiras de plástico, geralmente originados de embarcações pesqueiras, têm sido documentados como impactantes à vida marinha devido ao seu enredamento ou por ingestão direta dos resíduos pelos organismos (Laist, 1997; Arnould e Croxall, 1995). As partículas ingeridas podem novamente ser expostas ao ambiente na conseqüente morte dos animais (Watson, 2001).

Além disso, como os resíduos sólidos geralmente concentram-se em regiões oceânicas de convergência e áreas costeiras, há uma relação direta entre altas densidades de resíduos no ambiente e nos organismos (Carr, 1987), causando impactos negativos na vida aquática, principalmente na cadeia alimentar (Costa et al., 2009). Resíduos sólidos foram encontrados afetando ao menos cerca de 270 espécies de animais, incluindo $86 \%$ das espécies de tartarugas, 44\% de aves e $43 \%$ dos mamíferos marinhos e muitas outras espécies de peixe e crustáceo (Laist, 1997; Coe e Rogers, 1997). Há muitos relatos descrevendo a ingestão de pellets e/ou outros plásticos por peixes (Kartar et al., 1973), aves (Hays e Cormons, 1974; Morris, 1980; Bourne e Imber, 1982; Fry et al., 1987; Ryan et al., 1988; Furness, 1994; Robards et al., 1995; Blight e Burger, 1997; Krul e Moraes, 1998; Derraik, 2002; Barbieri, 2009; Colabuono et al., 2009) e tartarugas marinhas (Bjorndal et al., 1994; Bugoni et al., 2001). De uma maneira geral os animais morrem nos destroços plásticos de três maneiras diferentes: afogados; por exaustão, devido ao grande empecilho para se movimentarem; ou ainda pela ingestão dos fragmentos (Arnould e Croxall, 1995). Grandes quantidades de plástico ingeridas podem causar bloqueio intestinal ou úlceras no estômago, reduzindo a absorção de nutrientes (Connors e Smith, 1982; Furness, 1985b; Van Franeker, 1985) e ainda criando uma falsa sensação de saciedade (Kartar et al., 1973), alterações hormonais e atrasos nos períodos de reprodução dos animais (Azzarello e Van-Vleet, 
1987). Este fato pode resultar num decréscimo das reservas energéticas e da habilidade de sobreviver em condições ambientais adversas, com conseqüente redução nas taxas de crescimento (Colabuono et al., 2009) e até morte por inanição (Bugoni et al., 2001)(enfraquecimento extremo por ausência ou deficiência na assimilação do alimento).

Embora a maior parte do grupo não seja severamente impactada como um todo, mamíferos marinhos apresentam casos bem documentados e envolvem espécies ameaçadas de extinção. Wallace (1985) concluiu que cerca de 100.000 mamíferos marinhos e tartarugas morrem a cada ano no norte do Oceano Pacífico por se enroscarem em redes plásticas ou linhas de pesca. Pelagem, pele, gordura, músculo e eventualmente órgãos vitais são comprimidos ou até cortados fora pela rede (Arnould e Croxall, 1995). Um estudo apontou que quase 1.500 focas e leões marinhos morrem enredadas todo ano no sul da Austrália, prejudicando a recuperação dessas populações (Page et al., 2004). Outro estudo sobre o impacto de destroços plásticos em focas estimou que 15.000 animais da Geórgia do Sul (em uma população de cerca de 2 milhões) podem estar sendo enredados todo ano (Arnould e Croxall, 1995). Destes, cerca de 5.700 podem acabar morrendo. Como cerca de $12 \%$ dos animais enredados eram fêmeas, quase 700 potenciais reprodutores podem estar sendo perdidos anualmente.

Tartarugas marinhas são também propensas ao enredamento em destroços relacionados com a pesca, tais como linha sintética e redes de espinhéis descartados (Bjorndal et al., 1994). Além disso, Mascarenhas et al. (2008) sugeriram que pequenos fragmentos plásticos encontrados na câmara de ovos de tartaruga podem causar alteração nas trocas gasosas no ninho, alterar a temperatura de incubação causando desvio da sexagem natural e ainda obstruir a abertura da câmara de ovos e/ou impedir a chegada dos neonatos ao mar. Alguns trabalhos ainda evidenciaram o plástico como o material mais ingerido por tartarugas marinhas (Balazs, 1985; Plotkin e Amos, 1990; Sadove e Morreale, 1990; Shaver, 1991). Partículas de isopor e plástico em geral são regularmente ingeridas por estes animais, como os sacos de lixo que freqüentemente são confundidos com águas-vivas, alimento comum de tartarugas (Bugoni et al., 2001). Bjorndal et al. (1994) observaram em seus estudos que $71 \%$ das tartarugas tinham ingerido plástico e 38\% tinham ingerido linha de pesca, causando a morte de dois animais por impedimento do fluxo normal do alimento. Além disso, descobriram também que as tartarugas alimentam-se freqüentemente de pequenas partículas de 
plástico. Uma autópsia realizada numa tartaruga no Havaí revelou mais que 1000 pedaços de plástico no seu estômago (Watson, 2001).

Muitas aves ativamente coletam pedaços de rede e linha de pesca para a construção de ninhos, o que pode levar à estrangulação de adultos e juvenis (Laist, 1987). De 321 espécies de aves marinhas estudadas por todo o mundo, 111 (36\%) ingeriram plásticos acidentalmente (Watson, 2001). Aves marinhas no Alasca foram encontradas com o estômago completamente preenchido com plástico indigerível (Day, 1980). Estudos revelaram que aves jovens encontradas mortas com grande quantidade de plástico no seu trato digestório tinham seu peso diminuído em cerca 16\% em relação às aves que morreram por outras causas (Auman et al., 1997; Vooren e Brusque, 1999). Além disso, algumas espécies também alimentam seus filhotes com destroços plásticos (Auman et al, 1997; Vooren e Brusque, 1999). Um estudo com filhotes de albatrozes em Midway Island (Fry et al., 1987) Pacífico Central, produziu um surpreendente resultado de que $90 \%$ dos animais examinados continham plástico em suas goelas aparentemente alimentados por seus pais. O Atol de Midway localiza-se próximo ao Havaí, situado no meio do Oceano Pacífico, e recebe diariamente entulho plástico trazido do Japão e da costa oeste dos EUA por duas correntes que convergem para suas praias. O lixo de Midway causa a morte de quase metade dos 500.000 albatrozes que a cada ano nascem na ilha, já que alimentam seus filhotes com pedaços de plásticos que confundem com alimento (Auman et al, 1997).

Devido ao fato dos pellets serem pequenos (um dos menores itens do resíduo plástico), transparentes/translúcidos (pouco visíveis) e flutuantes (se forem menos densos que a água) são uma potencial ameaça para organismos aquáticos que os ingerem por engano, confundindo inclusive com ovos de peixes (Ananthaswamy, 2001; Watson, 2001). Estudos mostraram que 75\% (Day, 1980) e 76\% (Robards et al., 1995) do material plástico encontrado nos estômagos de aves era composto por pellets, assim como em petréis na Antártica (73\%; Van Franeker e Bell, 1988). No Havaí, 16 das 18 espécies de aves marinhas residentes ingerem plástico, sendo 70\% desta ingestão de pellets flutuantes (Fry et al., 1987). Vooren e Fernandes (1989) e Petry e Fonseca (2002) observaram um índice de contaminação por partículas plásticas respectivamente de $41 \%$ e $58 \%$ em aves Procellariiformes mortas em praias do Rio Grande do Sul. Os primeiros pesquisadores ainda chegaram a encontrar 34 pellets na moela de um mesmo indivíduo. Já Colabuono et al. (2009) encontraram pellets nos tratos digestórios de cerca de $46 \%$ dessa ordem de aves, tanto encontradas mortas em praias como coletadas 
incidentalmente por redes de pesca. Para o litoral paranaense este material também foi encontrado em aves (Krull e Moraes, 1998) e foi o item mais freqüente e abundante observado por Pelanda (2007), correspondendo a 54\% dos itens encontrados nos tratos gastrointestinais de aves Procellariformes. Barbieri (2009) revelou que, em 110 aves coletadas no litoral sul de São Paulo, 64,5\% tinham partículas plásticas em seus estômagos, sendo cerca de 36\% compostos por pellets. Pesquisadores também demonstraram a ingestão de pellets e micro-partículas de plástico por zôoplâncton e outros organismos componentes da base da cadeia alimentar marinha (Carpenter et al., 1972; Thompson et al., 2004). Outro estudo ainda sugeriu que a incidência de ingestão destes materiais por organismos planctívoros é maior em relação aos piscívoros, pois aqueles estão mais propensos a confundir os pellets com o alimento (Azzarello e VanVleet, 1987).

Os problemas causados por pellets plásticos não são apenas o enredamento e problemas alimentares. Estudos sugeriram que os aditivos usados na produção dos plásticos (emolientes, corantes e antioxidantes) geralmente são tóxicos e podem apresentar efeitos muito severos quando assimilados pelos organismos que os ingerem (Carpenter et al., 1972; Shiber, 1982; Van Freneker, 1985; Ryan et al., 1988; EPA, 1992a; Vooren e Brusque, 1999; Ananthaswamy, 2001). Além disso, os polímeros plásticos funcionam como veículos para alguns compostos tóxicos hidrofóbicos como DDTs (DicloroDifenilTricloroetano), PCBs (Bifenis policlorados) e fenóis (óleos tóxicos que não se dissolvem em água do mar)(Carpenter et al., 1972; Shiber, 1979 e 1982; Furness, 1983; Robards et al, 1995; Mato et al., 2001; Moore, 2002; Endo et al, 2005; Karapanagioti e Klontza, 2007; Rios et al., 2007). Estudos ainda observaram que os pellets podem acumular até um milhão de vezes o nível destas moléculas presente na água do mar (Mato et al., 2002) e que há um aumento nesta concentração de acordo com o tempo de exposição ao ambiente (Mato et al., 2001; McDermid e McMullen, 2004). Esse resultado também foi encontrado em outro estudo, que revela uma maior concentração de PCBs em pellets amarelados (Endo et al., 2005), cujo tempo de exposição ao sol e, conseqüentemente, à fonte de contaminação, é considerado maior. Mato et al. (2002) ainda revelaram que os pellets de áreas industrializadas contém maiores concentrações de PCBs em relação à áreas remotas (Rios et al., 2007) e que a concentração de poluentes em determinado ambiente determina o nível de contaminação dos pellets que ali se encontram (Ogata et al., 2009). Um outro estudo ainda mostrou que a coloração não está necessariamente relacionada com a concentração de poluentes, 
já que pellets de cores diferentes apresentaram taxas similares na adsorção de fenantreno (Karapanagioti e Klontza, 2007), um composto policíclico aromático. Além disso, PEs erodidos apresentaram o mesmo grau de adsorção de PEs virgens após 38 dias e os níveis de adsorção de PP foram 2 vezes menores em relação aos PEs (Karapanagioti e Klontza, 2007).

A conseqüência dos fatos descritos acima é a acumulação deste compostos nos tecidos adiposos e na linfa de organismos que ingerem as partículas contaminadas (Gordon, 2006; Ryan et al., 1988). A transferência de PCBs dos pellets ingeridos para as aves foi conclusivamente demonstrada e documentada nos tecidos adiposos de bobos (Puffinus gravis)(Ryan et al., 1988). A ingestão destas substâncias, algumas chamadas de "segunda geração" tóxica, pode não afetar diretamente os animais que os ingerem, mas sim acarretar problemas hormonais nos organismos que consomem esses animais e, indiretamente, em humanos (Moore, 2002). A questão das desrupções hormonais, fenômeno caracterizado por alterações hormonais e fisiológicas como, inclusive, alterações de sexo, tem se transformado em um dos grandes problemas do século 21, com implicações na baixa produção de esperma e aumento da taxa de nascimento de fêmeas (Moore, 2002).

Pellets flutuantes também podem estar relacionados com a migração de espécies exóticas, através da incrustação de propágulos, bactérias (Carpenter, 1972), algas e até briozoários (Gregory, 1983; Derraik, 2002), podendo causar desequilíbrios ecológicos para estes novos ecossistemas (Gregory, 1991 e 1999). Masó et al. (2003) salientou ainda a possibilidade de cianobactérias tóxicas se aderirem à superfície de partículas plásticas e se dispersarem nos oceanos, contaminando outras regiões.

De uma forma geral, apesar de todos estes estudos, os impactos e efeitos biológicos dos pellets não foram ainda claramente definidos ou demonstrados conclusivamente na maioria dos casos. Para entender a real dimensão do problema e buscar mecanismos de ação para equacionar esses impactos são necessários estudos básicos para avaliar as possíveis fontes de emissão para o meio e a real situação da contaminação do ambiente marinho e costeiro por esse poluente. 


\section{Fontes de pellets}

Como já mencionado, os pellets vêm dos subprodutos do refino do petróleo (principalmente a nafta) e do gás natural (principalmente o etano e o propano). De acordo com a classificação feita pela EPA (Agência de Proteção Ambiental) dos Estados Unidos (1992a), as indústrias de pellets foram divididas em 3 setores, acrescentado um setor relacionado com o empacotamento e transporte deste material. As indústrias de $1^{\text {a }}$ geração utilizam a matéria-prima para a produção do eteno e propeno (entre outros). As de $2^{\mathrm{a}}$ geração (produtoras) transformam estes em produtos intermediários (estireno) ou finais (polímeros de poliestireno, polietileno, polipropileno e elastômeros). Após serem formados, os pellets são empacotados e transportados (por vagão de trem ou caminhões e/ou navios de carga) para as indústrias de $3^{a}$ geração (processadoras ou transformadoras) para serem moldados em produtos de plásticos diversos (Pruter, 1987; EPA, 1992a).

Em seu Relato para o Congresso de 1990, a EPA (1990a) identificou os pellets de plástico como um item de particular preocupação, devido à evidência crescente no ambiente e os possíveis impactos ecológicos que este material poderia causar. Segundo a EPA (1992b), uma estratégia adequada para lidar com este problema é a identificação das possíveis fontes de pellets para o ambiente, além de apresentar formas de realizar o monitoramento dessas emissões (EPA, 1990a). Esses pellets vêm sendo encontrados em vários ambientes aquáticos, sugerindo uma perda deste material em algumas das etapas de produção, transporte e utilização (Carpenter et al., 1972; Hays e Cormons, 1974; Gregory, 1977 e 1978; Shiber, 1979, 1982 e 1987; Pruter, 1987; ITF, 1988; Ryan, 1988; EPA, 1992a; Khordagui e Abu-Hilal, 1994; Mato et al., 2001; Reddy et al., 2006; Costa et al., 2009).

Em resposta às preocupações públicas e governamentais com relação aos resíduos plásticos e à importância em determinar a quantidade e as possíveis fontes dos pellets no ambiente, o Conselho de Política Doméstica da Casa Branca criou, em 1987, o ITF (Interagency Task Force) em Resíduos Marinhos Permanentes, órgão presidido pela NOAA (National Oceanic and Atmospheric Administration) e com a participação de 12 Agências Federais, incluindo a EPA (EPA, 1992a). O ITF (1988) listou várias possíveis fontes de emissão de pellets no ambiente, incluindo: (1) produtores de pellets, (2) embarcações e outros veículos transportadores e (3) os processadores dos pellets. Assim, uma das recomendações do ITF para o manejo deste tipo de impacto foi a 
condução de pesquisas para determinar as emissões por terra e por água dos pellets (EPA, 1992a).

Paralelamente, a EPA, auxiliada pela SPI (Sociedade das Indústrias Plásticas dos EUA), desenvolveu diversas pesquisas na década de 1990 para entender o mecanismo das operações das indústrias de plásticos e identificar potenciais fontes de pellets no ambiente. Muitas fontes de emissão no ambiente aquático foram sugeridas, incluindo descargas e despejos de esgoto impróprio pelas indústrias de plásticos, vazamento de caminhões, vagões de trem e barcos, uso impróprio dos pellets e despejo de lixos e descargas de esgoto pelas cidades (EPA, 1992a). Essas evidências foram também levantadas em diversos outros trabalhos (Gregory, 1977; Shiber, 1979 e 1982; Reddy et al., 2006; Mascarenhas et al., 2008).

De acordo com a EPA (1992a), os pellets liberados pelas indústrias de plásticos chegam ao ambiente aquático por duas rotas:

1. Extravasamento de sistemas combinados de esgoto e águas pluviais (CSO Combined Sewer Overflow), onde os pellets derramados podem ser carregados pela água da chuva até as tubulações que transportam a água para o sistema municipal de tratamento de esgoto. Os pellets são então despejados no ambiente aquático através deste sistema quando o esgoto está combinado com essas tubulações. Essa possível fonte foi evidenciada pela ocorrência de pellets nestes sistemas na Pensilvânia e ainda nas estações de tratamento de água e esgoto da Filadélfia (EPA, 1992c).

2. Derramamento direto no ambiente aquático, devido ao manuseio de carga nos Portos e durante o transporte por embarcações (EPA, 1992a; Pelanda, 2007). Ambas as fontes podem despejar os pellets tanto em rios (geralmente regiões estuarinas) quanto diretamente no mar. Os resíduos provenientes dos rios têm três destinos principais: são soterrados e degradados, ficam presos na vegetação ou são transportados para o estuário e posteriormente depositados nas praias (Williams e Simmons, 1997).

Os pellets perdidos durante o transporte terrestre, durante os processos de carregamento e descarregamento da carga, também podem chegar ao mar por essas rotas. A retirada dos grânulos é feita através de tubos conectados a uma válvula no fundo do vagão/caminhão que deve ser bem fechada após o descarregamento. Em casos de manuseio indevido dessa válvula, ocorre um vazamento do material que, posteriormente, é 'lavado’ pela água da chuva e levado aos sistemas de drenagem das cidades (Gordon, 2006). Moore et al. (2001a) salientaram que provavelmente os pellets estejam sendo originados por perdas no transporte das indústrias produtoras aos 
processadores e ainda que alcançaram o ambiente costeiro por drenagem de rios, já que foram observados em abundância em todas as áreas costeiras amostradas. Além disso, a grande quantidade de resíduos sólidos urbanos veiculados por água de chuva no Rio Los Angeles pode ser evidenciada pela concentração desses resíduos na saída das tubulações (Gordon, 2006). Ryan e Swanepoel (1995) ainda demonstraram que a maior concentração de pellets ocorre nas proximidades de grandes centros costeiros urbanos e industriais e de áreas portuárias, evidenciando que a origem destes materiais devem ser de fontes locais.

Os estudos da EPA em áreas portuárias dos EUA ainda mostraram que: (a) os pellets também podem estar presentes em áreas portuárias inacessíveis à navios cargueiros e outros, indicando que estas embarcações não devem ser a única fonte de emissão de pellets no ambiente (EPA, 1990b, 1992a, b); (b) portos de cidades com sistemas CSO mais antigos contêm porcentagens significantes de pellets nos resíduos flutuantes (EPA, 1990b, 1992a, b); (c) portos próximos aos centros de produção, transporte e processamento têm maiores concentrações de pellets (EPA, 1990b, 1992a, b); (d) os pellets podem estar presentes nas descargas CSO e de água de chuva e nos sólidos coletados nas instalações de tratamento de esgoto (EPA, 1992c).

Estas descobertas sugerem que as indústrias de plástico permanecem como uma provável fonte de emissão de pellets no ambiente e indicam que significantes liberações por terra geralmente ocorrem (EPA, 1992a). Além dessas fontes, há também relatos da utilização desse material na limpeza de porões de navios, com os pellets sendo posteriormente descartados na água (Gomes, 1973; Reddy et al., 2006).

Uma vez no ambiente, os pellets podem tanto flutuar na ou próximo à superfície da água, ficar suspensos na coluna d’água, em médias profundidades, ou podem afundar e permanecer no leito oceânico. Esta característica de flutuabilidade depende do tipo de polímero usado para criar o pellet, dos aditivos utilizados para modificar as características da resina e da densidade da água receptora (EPA, 1992a). Muitos tipos de pellet flutuam na água doce ou marinha. Basicamente aqueles com densidades específicas menores que a água irão flutuar e os que apresentarem densidades maiores irão afundar. Devido ao fato da salinidade afetar a densidade, um pellet pode flutuar na água do mar mas afundar na água doce (EPA, 1992a). Um outro fator que afeta a flutuabilidade dos pellets são os processos hidrodinâmicos, como a turbulência e a tensão superficial da água. Por exemplo, a turbulência pode tanto submergir pellets que normalmente flutuariam ou ressuspender aqueles que afundariam 
abaixo da superfície ou que fossem direto para o fundo. Além disso, águas com alta tensão superficial, tais como aquelas que contém resíduos gordurosos ou descarga do sistema municipal de esgoto, podem também suportar partículas com uma densidade maior que a água ou manter outras que poderiam flutuar submergidas (EPA, 1992a).

\section{Distribuição Geográfica}

Embora os pellets sejam uma das formas menos perceptíveis de poluição por plásticos, eles estão presentes nos oceanos e praias do mundo (Carpenter et al., 1972; Kartar et al., 1973; Hays e Cormons, 1974; Morris e Hamilton, 1974; Gregory, 1977; Shiber, 1979, 1982 e 1987; Bourne e Imber, 1982; Gregory, 1983; Pruter, 1987; ITF, 1988; Ryan, 1988; Khordagui e Abu-Hilal, 1994; Redford et al., 1997; Moore et al., 2001a, b; Derraik, 2002; Kuryama et al., 2002; Kusui e Noda, 2003; McDermid e McMullen, 2004; Reddy et al., 2006). Eles têm sido relatados nos sedimentos e na superfície das águas de áreas costeiras e oceânicas, inclusive em regiões remotas como a Antártica (Van Franeker e Bell, 1988), evidenciando sua ampla distribuição.

Devido ao fato deste material ter um tempo de decomposição bastante longo, especialmente no mar, a quantidade flutuante nos oceanos está continuamente crescendo. O tempo de persistência dos pellets no ambiente aquático pode ser medido em anos, dependendo do tipo de resina, do tipo e quantidade dos aditivos e das reações das resinas e aditivos aos processos ambientais (intemperismo, ação da luz solar, das ondas, temperatura da água e do potencial biótico do ambiente)(EPA, 1992a; Andrady, 2000). EPA (1992a) estimou que o tempo de vida dos produtos plásticos varia de menos de 1 ano para mais de 600 anos, dependendo do produto. Outras estimativas variam entre 3 e 10 anos, chegando a valores da ordem de 30 a 50 anos dependendo da presença de aditivos (Derraik, 2002). No ambiente aquático, os tempos de vida podem ser afetados também por incrustação biológica e química, calor acumulado no interior do plástico, degradação por organismos microscópicos e disponibilidade de oxigênio atmosférico (EPA, 1990a).

Os pellets foram encontrados em diversos locais do planeta, como na superfície do Mar de Sargasso (Carpenter e Smith, 1972), ao longo da costa sul de Nova Inglaterra (Oceano Atlântico; Carpenter et al., 1972), no Reino Unido (Kartar et al., 1973; Morris e Hamilton, 1974) e no Mar do Caribe (Carr, 1987; Cole et al., 1990). Colton et al. (1974) estimaram cerca de 8.000 por km² no Atlântico Norte. Já no Mar de Sargasso foi 
estimada uma densidade de 3.500 por $\mathrm{km}^{2}$ (Carpenter e Smith, 1972; Watson, 2001). A mesma abundância de partículas plásticas foi encontrada nas águas da costa sudoeste da África, cuja composição por pellets foi de 40\% em 1978 (Ryan, 1988) e 55\% em 1994 (Ryan e Swanepoel; 1995).

A presença dos pellets na região costeira dos EUA foi primeiramente relatada no início dos anos 70 e desde então relatos vêm sendo feitos na maioria dos oceanos (EPA, 1992a). Mais recentemente, estudos da EPA sobre resíduos aquáticos revelaram ampla distribuição de pellets nos portos dos EUA localizados nas costas do Pacífico, Atlântico e do Golfo, com a presença destes sendo registrada em 13 dos 14 portos amostrados (EPA, 1992a). O maior número e variedade de pellets foi encontrado em Houston Ship Channel, em Houston, Texas, onde cerca de 700.000 pellets (98\% dos resíduos) foram coletados, sendo a maior parte de cor branca ou clara e de forma ovóide. Notavelmente, Houston tem uma das maiores concentrações de indústrias de plásticos dos EUA.

Durante os estudos, a EPA também encontrou pellets no sistema municipal de tratamento de esgoto da Filadélfia; eles foram coletados em 4 estações e a estimativa foi cerca de 20.000 pellets por dia presentes no esgoto tratado em apenas uma estação. Ainda, os pellets foram encontrados no sistema municipal de tratamento de água na Filadélfia e Boston e compuseram cerca de metade dos resíduos coletados numa única descarga de água de chuva. No final dos anos 80, a SPI relatou que a quantidade de pellets no ambiente pode ter sido resultado de inputs históricos provenientes de indústrias (SPI, como citado em CMC, 1988; EPA, 1992a). Em contraste, pesquisas da EPA conduzidas em vários portos dos EUA (EPA, 1990b, 1992a, b) mostraram uma ampla distribuição de pellets, muitos dos quais não alterados pela ação do tempo e que, provavelmente, haviam sido recentemente liberados no ambiente (EPA, 1992a).

Assim como nos oceanos, a maior parcela de resíduos sólidos encontrados em ambientes de praias arenosas é o material plástico (Gregory e Ryan, 1997; Madzena e Lasiak, 1997; Debrot et al., 1999; Moore et al., 2001; Derraik, 2002; Kusui e Noda, 2003; Abu-Hilal e Al-Najjar, 2004; Araújo e Costa, 2004; Mascarenhas et al., 2008; Costa et al., 2009; Ivar do Sul et al., 2009). A densidade média de resíduos encontrados na Praia do Cassino, RS, obteve valor máximo de 15 itens por metro linear e um total de $56 \%$ correspondeu ao material plástico, evidenciando um alto grau de contaminação (Wetzel et al., 2004). 
Os primeiros estudos sobre pellets em praias foram conduzidos na Nova Zelândia por Gregory (1977 e 1978). Os pellets também foram relatados ao longo da costa do Mar Mediterrâneo (Shiber, 1979, 1982 e 1987; Karapanagioti e Klontza, 2007), em várias partes dos Estados Unidos (Hays e Cormons, 1974; EPA, 1990b, 1992a, b, c, d; Moore et al., 2001a) e do Oceano Atlântico (Wilber, 1987), no Canadá (Gregory, 1983), Japão (Kusui e Noda, 2003; Endo et al., 2005), Havaí (McDermid e McMullen, 2004) e Arábia (Khordagui e Abu-Hilal, 1994). A quantidade de pellets presente nas praias pode ser muito alta, atingindo valores da ordem de 100 mil por metro linear de praia (Gregory, 1978; Derraik, 2002) e em média de 40.000/m em praias próximas aos centros industriais da Nova Zelândia (Gregory, 1977) e de 10.000/m nas praias de Bermuda (Gregory, 1983). Em 1998 foi documentado um estudo em praias de Orange County, Califórnia, que coletou cerca de 107 milhões de itens, pesando 12 toneladas (Moore et al, 2001a). Nos resíduos estavam inclusos espuma de plásticos, plásticos rígidos e pellets pré-produzidos, sendo este último o item mais abundante, constituindo 98.5\% do material coletado. Kusui e Noda (2003) encontraram pellets em 12 das 18 praias amostradas em seus estudos sobre resíduos sólidos na costa do Japão, chegando a 0.52 pellets $/ \mathrm{m}^{2}$ na superfície e 1.230 pellets $/ \mathrm{m}^{3}$ enterrados na areia. Já McDermid e McMullen (2004) calcularam cerca de 4.820 pellets $/ \mathrm{m}^{3}$ no Atol Midway, em Cargo Beach.

A quantidade e tipos de resíduos plásticos encontrados em praias estão relacionados com fatores como topografia, correntes e eventos de tempestades além da proximidade das fontes poluidoras (Storrier et al., 2007). Outros fatores como padrão de ventos, direção de correntes de deriva e processos de acreção/erosão de praias também foram ressaltados (Madzena e Lasiak, 1997; Wetzel et al., 2004). Os pellets podem ser mais facilmente visíveis em praias relativamente conservadas e com baixa atividade turística e ainda que não tenham atividades de limpeza freqüentes, já que ambas as atividades favorecem o soterramento dos grânulos na areia e/ou pedras (Shiber, 1987). Observações preliminares revelaram que os pellets podem ser encontrados nas praias em duas porções (ver Wilber, 1987): (1) na linha de deixa da maré na região entremarés e (2) na região de areia seca do supralitoral, sendo que nesta última é onde eles se concentram. Além disso, amostrar a quantidade e caracterização dos pellets que entram no ambiente também é importante para averiguar se este problema é recente ou antigo e ainda para estimar as possíveis fontes de emissão. 
Estudos sobre pellets de plástico no Brasil ainda são muito escassos e recentes de forma que um levantamento da composição e quantidade de pellets que tenha procurado entender o padrão de distribuição, tanto em macro quanto em micro-escala ainda não foi realizado, fato que pode ser fundamental em programas de diagnóstico e monitoramento. Há apenas alguns registros para algumas praias dos Estados do Rio Grande do Sul (RS)(Pianowski, 1997), Paraná (Pelanda, 2007), Pernambuco (Costa et al., 2009), Rio Grande do Norte (Ivar do Sul et al., 2009) e São Paulo como Santos, Ubatuba e Guarujá, inclusive em praias localizadas em unidades de conservação (A. Turra et al., 2008). Em 1997 foi desenvolvida uma pesquisa nas praias do RS resultando em densidades médias de pellets de 112/m por ano na Praia do Taim e de 163/m no Parque Nacional da Lagoa do Peixe, evidenciando ainda que a maior porcentagem (90\%) foi encontrada na cor branca (Pianowski, 1997). Costa et al. (2009) encontraram uma densidade média de 1000 pellets $/ \mathrm{m}^{2}$ na linha de deixa na praia da Boa Viagem em Recife (PE). Em 2009 foram também encontrados pellets na linha de deixa de praias do Arquipélago de Fernando de Noronha (RN) a uma densidade de 67 unidades $/ \mathrm{m}^{2}$ (Ivar do Sul et al., 2009).

Considerando a importância e a quantidade de pellets produzidos no Brasil, as possibilidades de impactos citadas acima e o quase completo desconhecimento do problema no país esse estudo foi planejado para levantar informações a respeito dos padrões de distribuição espacial do pellets em pequena escala, suas características e eventuais fontes. Para tanto, foi escolhida a região da Baixada Santista por ter uma posição estratégica para a comercialização desse produto e ainda devido à observações preliminares da abundância desse resíduo ao longo de todas as praias que compõem a Enseada de Santos. 


\section{OBJETIVOS}

\section{Objetivos gerais:}

Avaliar a abundância e a distribuição de grânulos plásticos (“plastic pellets”) nas praias da Enseada de Santos, litoral do Estado de São Paulo, área com grande abundância desse material, bem como sua taxa de entrada e características químicas e morfológicas. Pretendeu-se ainda identificar empresas que produzem, transportam ou utilizam os pellets para se iniciar um processo para definir medidas para impedir ou reduzir o aporte destas substâncias para os estuários e, conseqüentemente, para o mar.

\section{Objetivos Específicos:}

Dentre os objetivos específicos estão:

1. Compreender o padrão de distribuição dos grânulos plásticos em uma área com grande concentração deste material, praias da Enseada de Santos, visando a definição de um desenho amostral quantitativo para ser replicado em outros ambientes. Assim, pretendeu-se:

1.1. Avaliar a distribuição dos grânulos em profundidade no sedimento;

1.2. Avaliar a distribuição dos grânulos ao largo da praia (distribuição vertical; perpendicular à linha da água);

1.3. Avaliar a distribuição dos grânulos ao longo da praia (distribuição horizontal; paralela à linha da água).

2. Calcular a taxa de entrada dos grânulos nesta área, utilizando a quantidade na linha de deixa como marcador;

3. Descrever as características químicas e morfológicas dos grânulos, comparando diferentes profundidades no sedimento e avaliando sua variabilidade espacial e temporal na linha de deixa.

4. Identificar as possíveis fontes de emissão de grânulos para a Enseada de Santos. 


\section{ÁREA DE ESTUDO}

\section{Característica Físicas}

A área de estudo compreende as praias da Enseada de Santos (23ํํำ'27" S e $45^{\circ} 19^{\prime} 48^{\prime \prime}$ W) e está localizada nos municípios de Santos e São Vicente, pertencentes à região metropolitana da Baixada Santista, porção central do litoral do estado de São Paulo, região sudeste do Brasil (Figura 2).

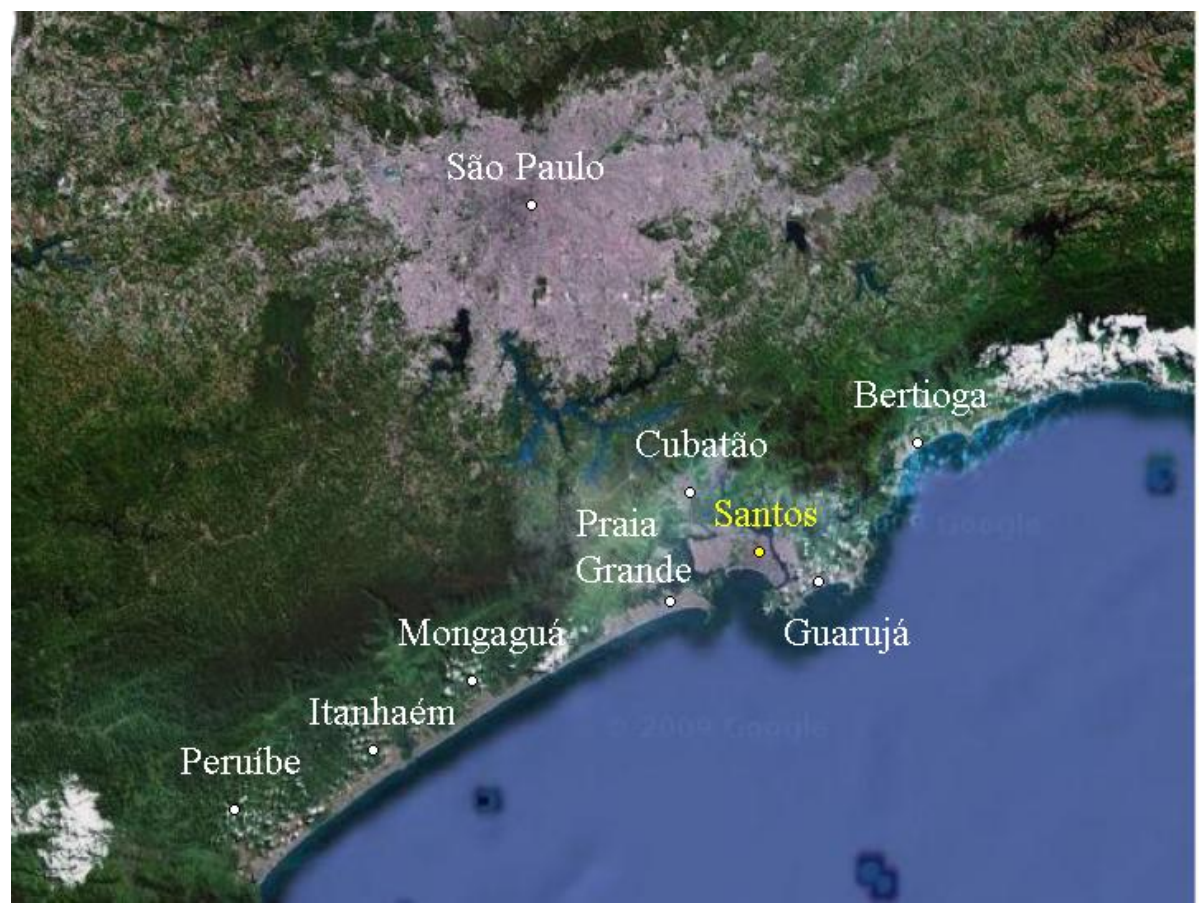

Figura 2. Região Metropolitana da Baixada Santista. (Fonte: Google Maps)

A região apresenta clima litorâneo de transição e registra temperaturas extremas de $42^{\circ} \mathrm{C}$ e mínimas inferiores a $10^{\circ} \mathrm{C}$, sendo a temperatura média de $20^{\circ} \mathrm{C}$, com índice pluviométrico elevado, de 2.000 a 4.500mm por ano (Moser et al., 2005). Durante a estação seca a média diária é de $10 \mathrm{~mm}$ enquanto na estação chuvosa os valores estão entre 30 e 180mm (DAEE, 1999).

A drenagem de água doce para o sistema estuarino de Santos e São Vicente (Figura 3) é feita por uma vasta rede de rios que nascem na Serra do Mar e que correm para a planície costeira (Goldenstein, 1972). Nesta, o conjunto de rios se ramifica em um complexo sistema de canais de maré, formando muitas ilhas estuarinas (Bonetti, 
2000). Na parte insular os rios são canalizados, enquanto na parte continental os rios formam meandros.

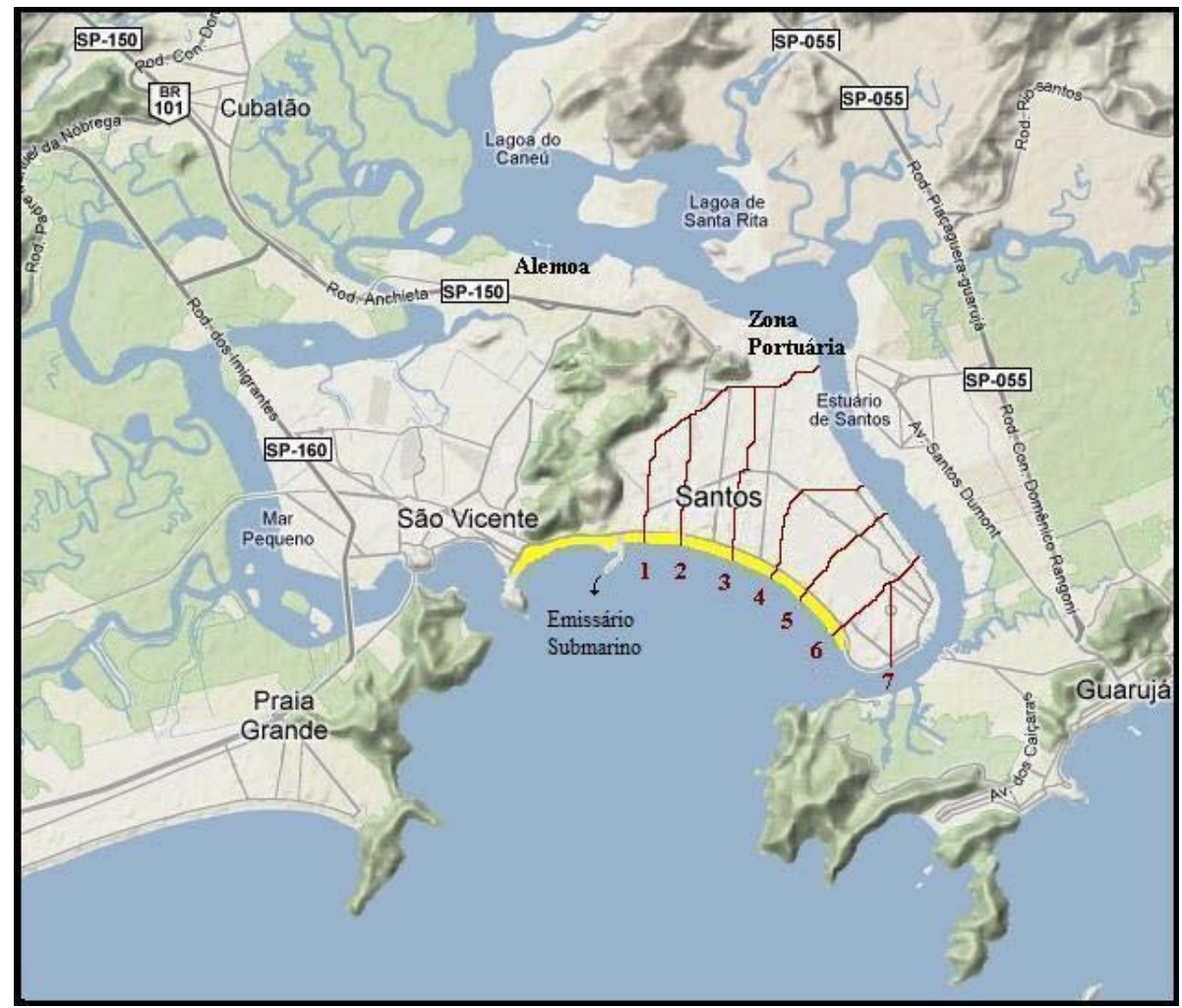

Figura 3. Enseada e Estuário de Santos e São Vicente. Os canais de Santos (1 a 7) estão evidenciados em cor vermelha e as praias amostradas em cor amarela (aquelas pertencentes aos respectivos municípios estão separadas pelo emissário submarino). (Fonte: Google Maps)

Ao contrário de outras cidades, os 6 km de praias de Santos são, na verdade, uma praia só, uma única enseada. A cidade é cortada por 7 canais (Figura 3), que acabam servindo de divisa entre os bairros e, conseqüentemente, cada trecho de praia entre os canais recebe o nome do bairro a que pertence. Esses canais são uma particularidade da cidade de Santos, construídos perpendicularmente à linha da costa, a uma distância de aproximadamente $1 \mathrm{~km}$ uns dos outros, com o objetivo de conectar o mar ao ambiente estuarino para a circulação da maré e do sistema de drenagem da cidade. A numeração inicia-se próximo à divisa entre os municípios de São Vicente e Santos, no centro da Enseada, e termina após a última praia da enseada, na porção inicial do Estuário de Santos. Já as praias pertencentes ao município de São Vicente (e ainda à Enseada de Santos) somam aproximadamente $1.5 \mathrm{~km}$ de extensão. As condições naturais não diferem muito de uma praia para outra. Todas são dissipativas e apresentam declividade sub-horizontais (inclinação $<10^{\circ}$ )(Magini et al., 2007). 
O Canal do Estuário de Santos apresenta um fluxo de água doce que varia de $24 \mathrm{~m}^{3} / \mathrm{s}$ a $127 \mathrm{~m}^{3} / \mathrm{s}$, incluindo o Rio Cubatão e a descarga da Usina Hidrelétrica Henry Borden (Sondotecnica, 1977). As amplitudes médias de maré são aproximadamente de 1m (Moser et al., 2005). Os canais do Estuário de Santos e São Vicente cobrem uma área de cerca de $44.100 \mathrm{~m}^{2}$ (Moser et al., 2005). A boca do Canal de São Vicente tem cerca de 300m de largura e 6m de profundidade, enquanto o Canal de Santos tem 500m de largura e 12m de profundidade (Moser et al., 2005). A Enseada de Santos possui abertura voltada para SE-S e uma barra de aproximadamente $12 \mathrm{~km}$ de extensão, sendo sua área total de $30 \mathrm{~km}^{2}$ (DHN, 2003).

A Baía de Santos é relativamente abrigada e sofre influência tanto das águas provenientes de correntes costeiras como dos canais de Santos e São Vicente. A circulação na área tem sido estudada em diversos trabalhos, como os de Harari e Camargo (1995), que analisaram registros do nível do mar de 1944 a 1989, Camargo et al. (1999), que realizaram estudo estatístico da maré meteorológica no sudoeste do Atlântico, e de Harari e Camargo (1997 e 1998), Harari et al. (1999 e 2000) e Harari e Gordon (2001), que modelaram a circulação tridimensional. As modelagens numéricas foram desenvolvidas para representar os processos hidrodinâmicos que envolvem esta região e, assim, auxiliar na compreensão dos processos costeiros como um todo (Harari et al., 2000). Estes modelos consideram os padrões de circulação da água na dispersão de poluentes dependentes da interação dos efeitos das marés (maré enchente e vazante em períodos de marés de quadratura e de sizígia), ventos (em condições predominantes e os gerados por intensas frentes frias) e efeitos da densidade da água do mar (incluindo a influência das descargas estuarinas (Harari et al., 2000).

Moser et al. (2005) demonstraram que a velocidade das correntes no Canal de Santos é maior durante os períodos de maré vazante na maré de sizígia e que os compostos particulados estão também relacionados às marés vazantes tanto na de sizígia quanto na maré de quadratura. Durante as marés de quadratura na estação chuvosa há uma maior saída de compostos particulados dos canais de Santos e São Vicente devido ao aumento da descarga de água doce e à menor variação nos níveis de maré $(0,1 \mathrm{~m})$; a entrada destes compostos nos canais só ocorre durante a maré de sizígia na estação seca (Moser et al., 2005). Durante a estação chuvosa eventos de deslocamento estão associados a assimetrias de correntes, tais como condições de convergência e divergência, comuns em todos os ciclos da maré (Harari e Camargo, 1997; Harari et al., 2000), e que reproduzem alterações no fluxo de ambos os canais. 
A análise das componentes da maré astronômica em séries temporais do nível do mar no Porto de Santos mostra a preponderância das energias associadas aos efeitos de maré na circulação da área (Harari e Gordon, 2001). De fato, os trabalhos de Harari e Camargo (1995 e 1998) e Harari et al. (1999 e 2000) demonstram que, na ausência de efeitos meteorológicos significativos, a circulação de maré astronômica pode ser considerada como uma boa aproximação da circulação total. No entanto, citam que efeitos meteorológicos extremos, como por exemplo frentes frias intensas, podem gerar circulações e variações do nível do mar com a mesma ordem de grandeza das geradas pelas marés.

As praias de Santos são constantemente afetadas pela entrada de frentes frias, com ventos e correntes de direção sul, responsáveis pelo aporte, circulação e retirada de sedimentos (Magini et al., 2007). Em 2005 foi realizado um estudo demonstrando que há um maior volume de areia nos canais 1, 2 e 3, confirmando que ocorre uma maior sedimentação na porção central da baía, região que sofre grande influência das correntes do canal do Porto de Santos e das ondas e correntes de direção sul (Magini et al., 2007). Este estudo também corroborou pesquisas anteriores sobre circulação de fundo e de superfície na Baía de Santos, que delimitaram duas células de circulação (vórtices), criando áreas de pouca energia devido à refração de correntes (entre os canais 2 e 3) e demonstraram, adicionada às correntes do Canal do Porto, o transporte residual de leste para oeste (Harari e Camargo, 1997 e 1998; Harari et al., 2002). Na década de 70 foi construído o píer do Emissário Submarino, próximo ao canal 1, afetando o aporte de sedimento para as praias posteriores (em direção Oeste), como a praia de Itararé, pertencente ao município de São Vicente. Esta construção levou à modificações na composição dos sedimentos das áreas em questão: na margem leste há predominância de sedimentos argilosos, enquanto na porção sul há deposição principalmente de areia (Magini et al., 2007).

Da zona de erosão (updrift) para a de deposição (downdrift) os sedimentos tornam-se finos e melhor selecionados, a energia das ondas decresce, a topografia da parte anterior da praia torna-se mais plana e a largura da praia aumenta (Souza e Suguio, 1998). Neste processo, ondas incidentes são o fator mais importante no controle de correntes longshore, com menor contribuição de ventos e correntes de maré (Souza, 1997). 


\section{Característica Sócio-Econômicas}

A cidade de Santos é densamente povoada, com características urbanas voltadas para a verticalização. Durante as temporadas de verão, férias e feriados prolongados, estima-se uma população flutuante de aproximadamente 1,5 milhão de pessoas. A população da Baixada Santista segundo o IBGE (2007), considerando os municípios de Santos, São Vicente, Guarujá e Cubatão, foi estimada em torno de 1.2 milhão de habitantes. Santos tem uma densidade demográfica de 1.488 hab $/ \mathrm{km}^{2}$ e é um município altamente urbanizado (taxa de urbanização: 99,47\%) ${ }^{4}$.

Em função dessa ocupação há uma grande pressão sobre os sistemas de coleta e tratamento de efluentes urbanos. O sistema de disposição oceânica de esgotos de Santos/São Vicente está em operação desde 1978 e atende à maior parte das residências de Santos e metade das residências em São Vicente. É constituído por uma estação de pré-condicionamento (EPC) e um emissário. Na EPC o esgoto passa pelas etapas de précloração, caixa de areia, gradeamento, peneiramento em malhas de 1,5mm e póscloração, em seguida sendo enviado pelo emissário à região central da Baía de Santos cerca de 4km da costa (Abessa et al., 2009). Além disso, Santos não apresenta descargas de esgotos combinadas com a drenagem, com a água da chuva sendo escoada diretamente para as praias através do sistema de canais.

Dentre as atividades econômicas da Baixada Santista destacam-se: transporte marítimo (porto), indústrias leves, comércio, prestação de serviços, turismo e pesca. A economia em Santos é basicamente formal. Segundo números de 2002 divulgados pelo NESE - Núcleo de Estudos Socioeconômicos da Universidade Santa Cecília, o setor que mais emprega em Santos é o de serviços (65,4\%), seguido pelo comércio (18,4\%), enquanto o setor da indústria emprega cerca de 7,2\% da população, com um total de 756 unidades (5,6\% dos estabelecimentos). A economia do município de São Vicente é principalmente baseada no comércio e turismo e o setor industrial não é fortemente desenvolvido.

Santos possui hoje o maior porto da América Latina (Figura 4), tanto em movimentação de cargas (mais de 70 milhões de toneladas de cargas diversas só em

\footnotetext{
${ }^{4}$ http://www.vivasantos.com.br
} 
2005), quanto em infra-estrutura (7.7 milhões de $\mathrm{m}^{2}$ e $14 \mathrm{~km}$ de cais) ${ }^{5}$. Engloba uma área que concentra 55\% do PIB do Brasil, 49\% da produção nacional e 49\% do mercado de consumo (os estados de São Paulo, Minas Gerais, Goiás, Mato Grosso e Mato Grosso do Sul) ${ }^{6}$. Santos movimenta anualmente um quarto do valor dos produtos negociados pelo país no mercado internacional. No primeiro semestre de 2006, a participação de Santos na Balança Comercial Brasileira foi de 25,9\% (valores em U\$ FOB $)^{3}$.

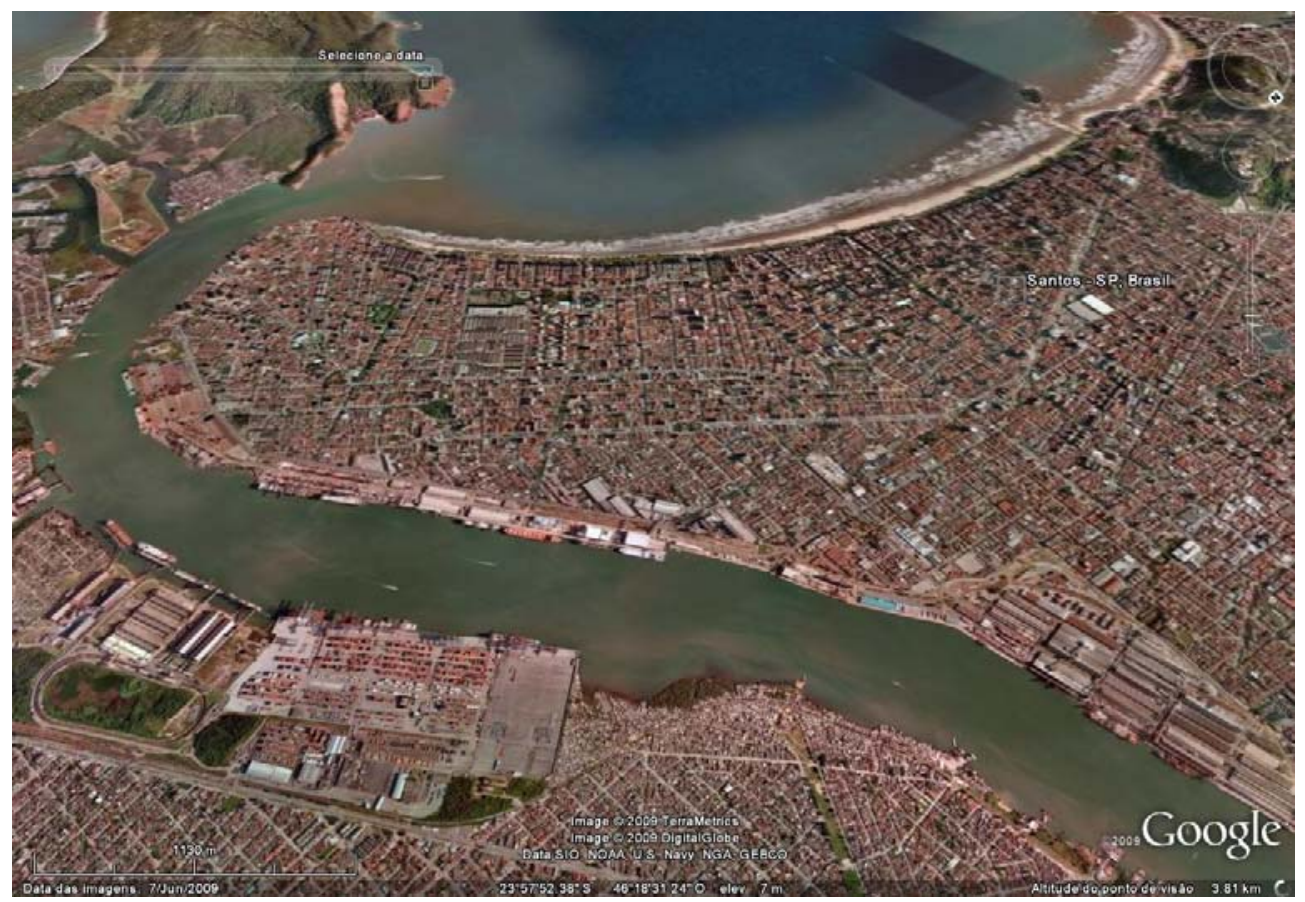

Figura 4. Visão parcial do Porto e Enseada de Santos. Imagem do Google Earth.

Duas grandes ferrovias escoam cargas do interior do país para o Porto de Santos: A MRS - M.R.S. Logística S/A (antiga RFFSA), a Ferroban - Ferrovias Bandeirantes S/A (antiga FEPASA) e a Ferronorte S/A². Além das ferrovias, o tráfego de cargas que chegam e saem do porto se dá também pelo sistema Anchieta-Imigrantes (Ecovias), pela rodovia Piaçaguera-Guarujá, pela BR-101 (Rio-Santos) e pela SP-55 (Rodovia Pe. Manoel da Nóbrega)².

\footnotetext{
${ }^{5}$ http://www.metro.santos.sp.gov.br

${ }^{6}$ http://www.portodesantos.com
} 
O Porto de Santos é estruturado em muitos terminais de embarque de produtos, com destaque para os de grãos, cereais, açúcar e fertilizantes, e os de granéis líquidos e sólidos (em cuja classificação encontram-se os grânulos de plástico). Existem também os terminais de uso privativo, como os da Cosipa, Ultrafértil, Braskem e Dow Química.

Cabe registrar que Santos é o pólo da Região Metropolitana da Baixada Santista. Todas as áreas urbanas desses municípios são limítrofes, acarretando uma forte interdependência entre eles e uma forte influência de São Vicente e Guarujá sobre a Enseada de Santos. Destaca-se também Cubatão por sua grande concentração industrial, principalmente no ramo petroquímico, que se instalou na região há cerca de 50 anos e que teve um aumento considerável até a década de 70 (cerca de 23 indústrias) ${ }^{7}$.

Esta intensa atividade industrial, principalmente em Cubatão, juntamente com a presença do maior porto da América Latina, geram uma alta concentração de resíduos sólidos industriais no Estuário de Santos - São Vicente (Hortellani et al., 2008). Nesses pontos e em suas proximidades, como em locais que contém armazéns, depósitos, silos e pátios de manobras, ocorrem diversas emissões de poluentes para o ambiente estuarino e marinho, principalmente relacionado com perdas de produtos nas operações de carga/descarga, lavagens de containeres e porões de navios (Hortellani et al., 2008). Esta situação, somada ao incremento da ocupação urbana na região e à falta de um tratamento adequado aos resíduos sólidos, potencializa a poluição ambiental que, de qualquer maneira, acaba desaguando no oceano. Além disso, a presença do grande número de refinarias e indústrias petroquímicas na região reforça ainda mais a possibilidade de emissão de resíduos e pellets de plástico no ambiente.

\footnotetext{
${ }^{7}$ http://www.metro.santos.sp.gov.br
} 


\section{MATERIAL E MÉTODOS}

\section{Compreender o padrão de distribuição dos grânulos plásticos nas praias da Enseada de Santos}

\subsection{Avaliar a distribuição dos grânulos em profundidade no sedimento}

Esta amostragem foi realizada entre outubro de 2007 e fevereiro de 2008, em uma região do supralitoral da Enseada de Santos em um local verificado (visualmente) como de grande concentração de pellets (entre os canais 5 e 6 da Enseada de Santos; Figura 3). Foi estabelecida uma malha amostral de 50m (perpendicular à linha da água) x 100m (paralela à linha da água) em que 10 amostras de $1 \mathrm{~m}^{2}(1.0$ x $1.0 \mathrm{~m})$ foram coletadas a cada $10 \mathrm{~cm}$ até $1 \mathrm{~m}$ (Figura 5). A cada nova profundidade a porção superior do sedimento era retirada e a porção inferior processada. Isto se fez necessário para garantir que as amostras das diferentes profundidades não fossem tomadas em uma única unidade amostral, isto é, para que elas fossem estatisticamente independentes. O sedimento amostrado foi despejado em baldes com água do mar para que os pellets pudessem flutuar (flotação). Eles foram retirados do sobrenadante por peneiras de malha fina $(1 \mathrm{~mm})$ e separados por amostra para posterior contagem (pellets $/ 0,1 \mathrm{~m}^{3}$ ) e caracterização morfológica (ver Objetivo 3). Esta técnica permitiu que a triagem do sedimento fosse realizada em campo de uma maneira razoavelmente rápida.

A hipótese nula de que os grânulos distribuiriam-se de forma homogênea em diferentes profundidades do sedimento foi testada com uma análise de variância do tipo I de um fator (profundidade - fator fixo com 10 níveis) seguida do teste SNK para comparações múltiplas a posteriori (Underwood, 1997). Uma vez que os grânulos no geral possuem uma densidade menor que a água do mar, principalmente os encontrados em praias arenosas (EPA, 1992a), eles teriam uma tendência a não serem soterrados e a concentrarem-se portanto na porção mais superior do sedimento, fato que define a hipótese alternativa aventada. 


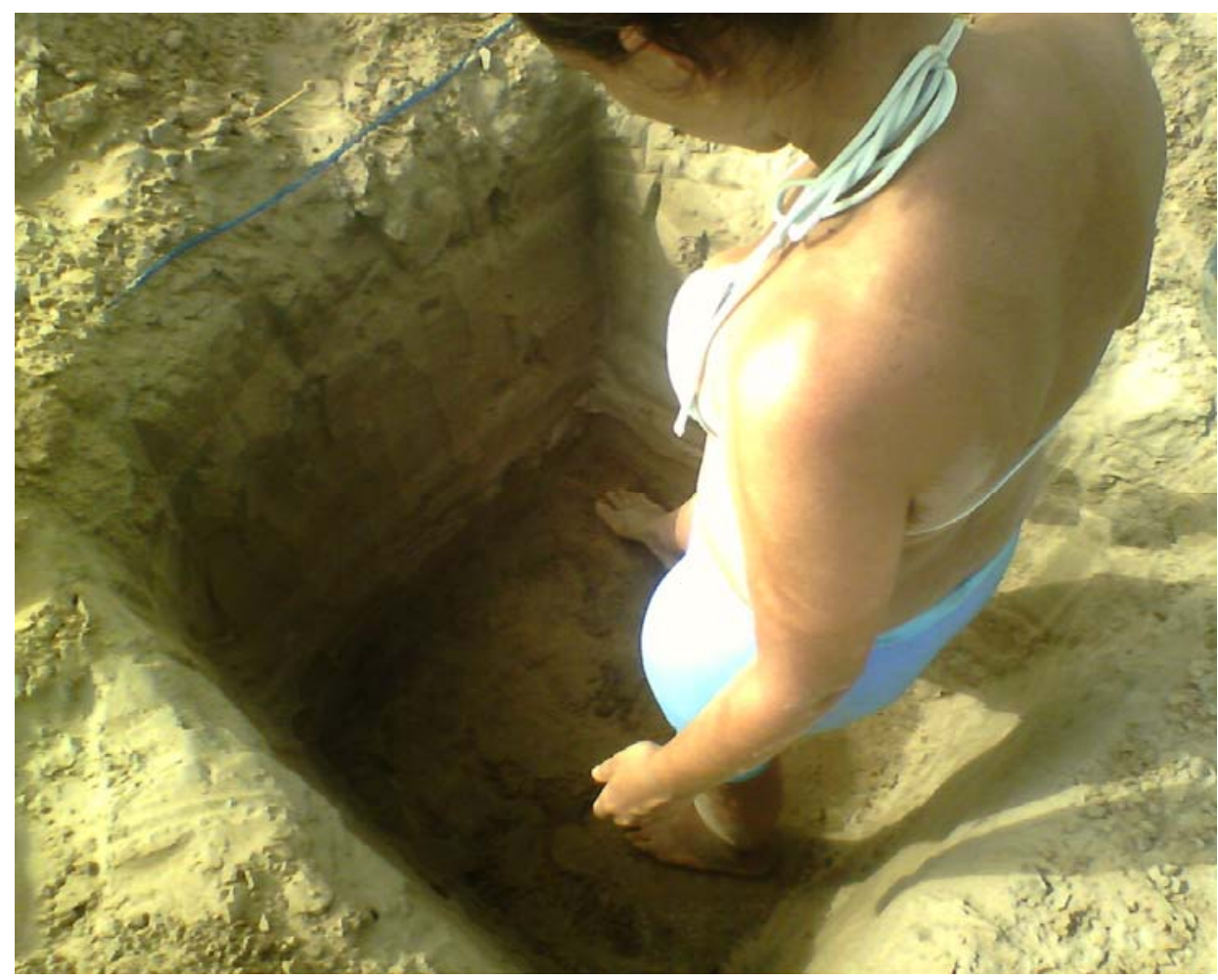

Figura 5. Coleta para amostragem da distribuição dos grânulos em profundidade no sedimento.

\subsection{Avaliar a distribuição dos grânulos ao largo da praia (distribuição} vertical)

Com base na dinâmica de deposição dos pellets era previsto que eles se concentrassem na região superior das praias. Assim, mesmo na região do supralitoral esperava-se que a abundância dos grânulos aumentasse com a distância da água ou a proximidade das dunas, vegetação ou construções. Neste sentido, um estudo para avaliar a distribuição ao largo (vertical) desta região da praia foi realizado entre março e julho de 2008 em outra área da Enseada de Santos em que a abundância dos grânulos também foi visivelmente alta (entre os canais 4 e 5; Figura 3).

Para a realização dessa avaliação uma adequação metodológica foi necessária para compatibilizar os resultados do objetivo 1.1 (distribuição em profundidade) com a escala de amostragem pretendida aqui. Como o método utilizado exigiu muito esforço físico e mão-de-obra auxiliar devido ao grande volume de sedimento (já que os pellets foram encontrados enterrados), foi necessária uma mudança do amostrador para uma cavadeira tipo trado de 6" de diâmetro, espécie de cavadeira/broca muito comum em obras, para retirar sedimento a $1 \mathrm{~m}$ de profundidade (Figura 6). 


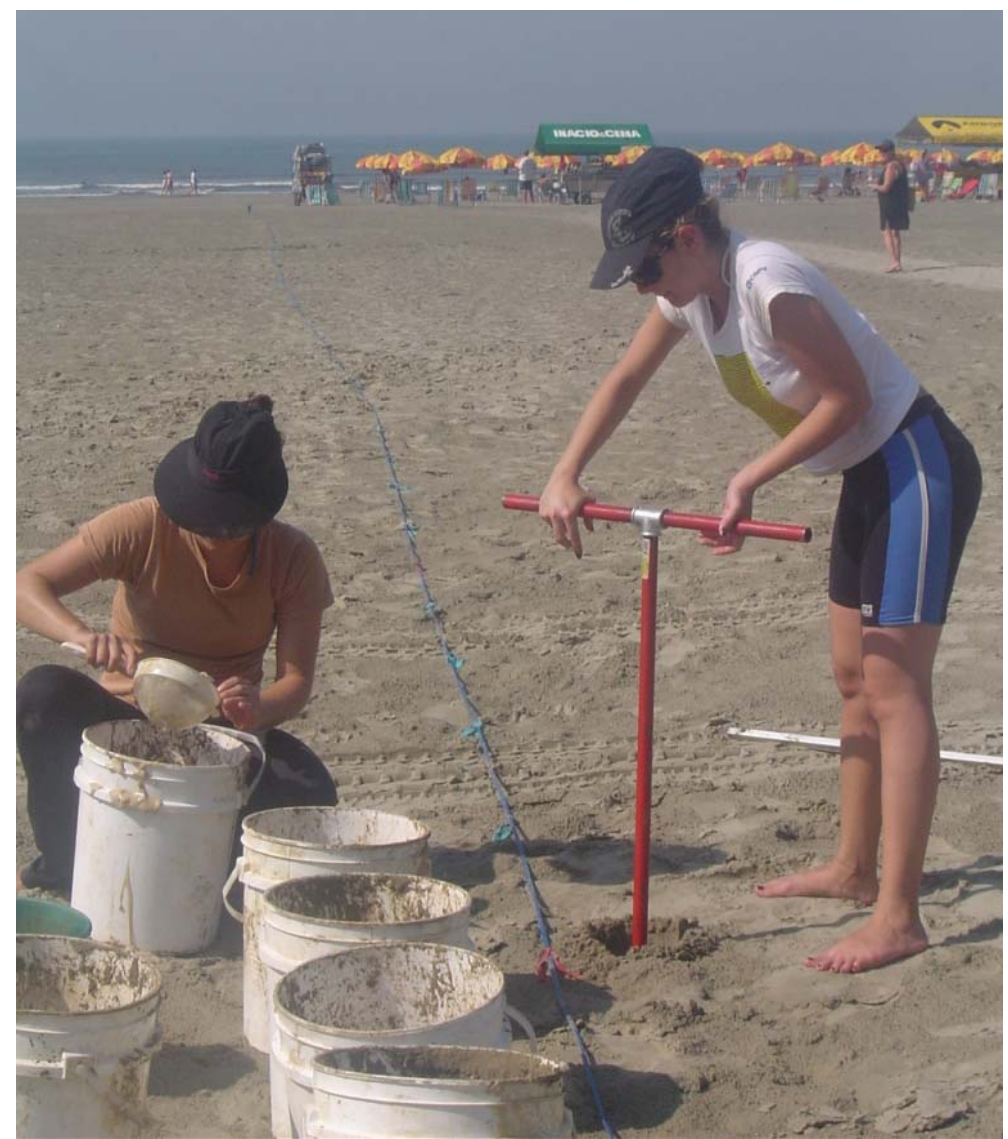

Figura 6. Procedimentos de coleta para avaliar a distribuição ao largo (vertical) da Enseada de Santos utilizando uma cavadeira tipo trado de 6' de diâmetro.

A área amostrada tinha 50m de comprimento (ao longo da praia) e largura de $78 \mathrm{~m}$, desde a franja do supralitoral (limite entre a face praial e o pós-praia) até a parte mais superior da praia (equivalente ao pós-praia) e foi dividida em 12 alturas eqüidistantes (a cada 6,5m). Em cada altura foram retiradas 25 amostras aleatórias posicionadas paralelamente à linha da água, até a profundidade de 1m, totalizando 300 amostras. Essa profundidade foi utilizada pois os pellets concentram-se nessa faixa e uma unidade amostral padrão tinha que ser definida para permitir a comparação entre as diferentes alturas. Os grânulos foram então triados como exposto acima e separados por amostra para posterior caracterização morfológica e contagem. O número de pellets foi plotado de acordo com o volume estimado por coluna de sedimento $\left(0.018 \mathrm{~m}^{3}\right)$, levando em consideração o diâmetro do trado $\left(6^{\prime}=0.1524 \mathrm{~m}\right)$ e a profundidade de $1 \mathrm{~m}$.

A hipótese nula de que os grânulos se distribuiriam de forma homogênea ao largo da região amostrada, isto é, entre as diferentes alturas, foi então testada utilizandose uma análise de variância (ANOVA) do tipo I de um fator (altura - fator fixo com 12 níveis) seguida do teste SNK para comparações múltiplas a posteriori (Underwood, 
1997). Para apresentação dos dados as densidades médias dos pellets foram plotadas considerando-se o perfil topográfico de cada área. Para tanto, esse foi avaliado pelo método das Balizas de Emery (Emery, 1961), registrando o desnível da praia a intervalos de 5 metros.

\subsection{Avaliar a distribuição dos grânulos ao longo da praia (distribuição}

\section{horizontal)}

Seguindo-se a lógica dos processos de sedimentação em praias, a baixa densidade específica dos grânulos sugere que eles seriam depositados predominantemente em ambientes deposicionais. Não seria esperado que houvesse deposição em áreas de erosão. Com o intuito de se testar a hipótese nula de que os grânulos se distribuiriam homogeneamente ao longo da praia, 15 áreas eqüidistantes (área - fator fixo com 15 níveis; Figura 7) foram amostradas ao longo de toda Enseada de Santos (os pontos 1 a 10 correspondendo às praias de Santos e 11 a 15 às praias de São Vicente) durante julho de 2008 e Dezembro de 2009. Em cada área foram sorteados ao acaso 3 transectos, ao longo de uma faixa de 20m paralela à linha da água, os quais foram então divididos em 10 alturas (distância do limite do pós-praia) eqüidistantes. Em função disso, a largura de cada área (ou o comprimento do transecto) e a posição de cada altura variaram de acordo com o tamanho do pós-praia. Entretanto, a área amostrada, e o respectivo número de amostras, em cada transecto foi de fato variável, já que não incluiu todo o pós praia mapeado na definição dos transectos e sim a porção em que os pellets foram registrados incluindo a primeira amostra com nenhum pellet em direção ao mar (ver Defeo e Ruenda, 2002). 


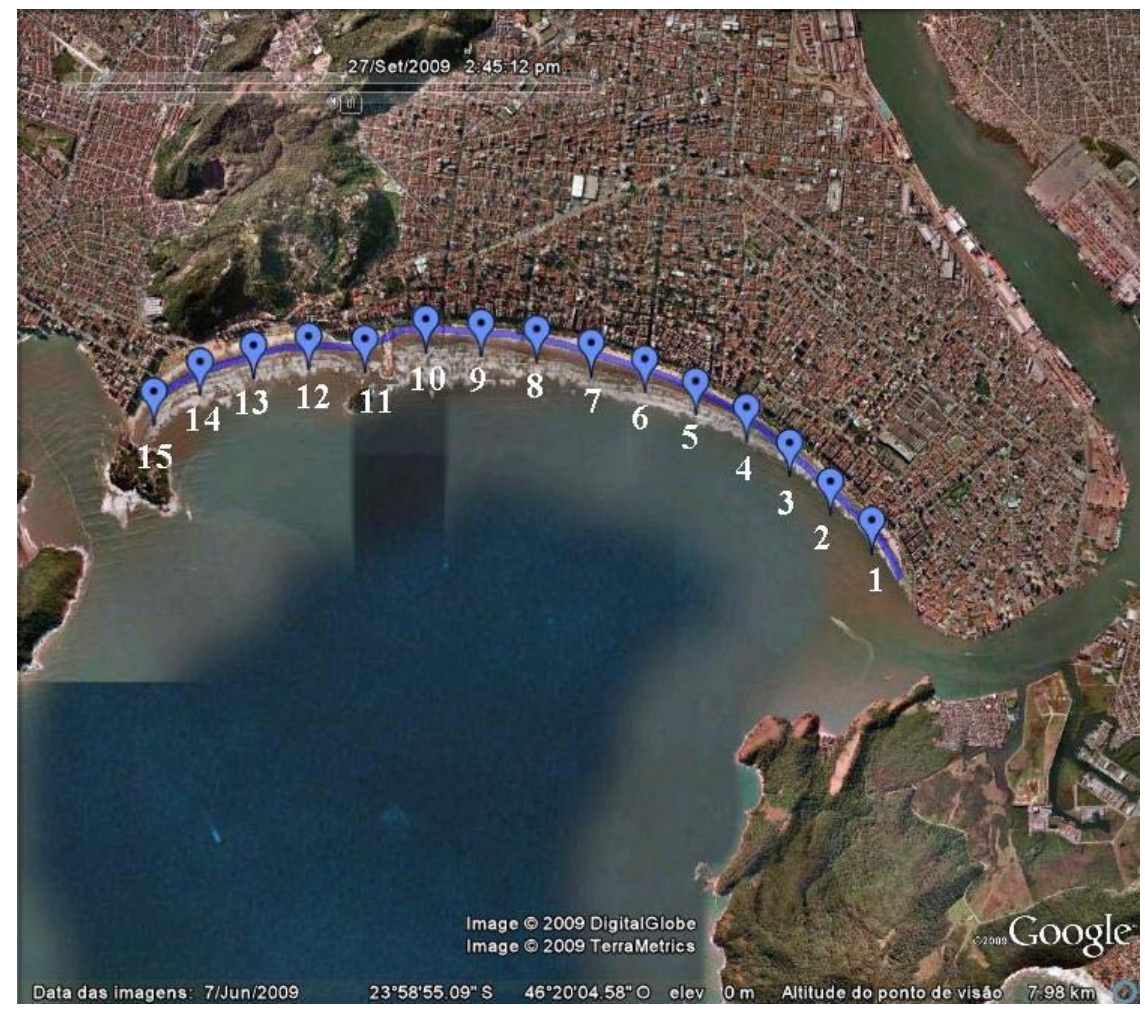

Figura 7. Áreas de coleta para amostragem da distribuição dos grânulos ao longo da praia (distribuição horizontal).

A profundidade de cada uma das amostras em cada transecto foi definida com base no perfil da praia. Supôs-se que a profundidade máxima em que um pellet poderia ser encontrado seria limitada pela profundidade mínima do lençol freático, considerando uma situação extrema em que toda a areia da praia acima do nível 0,0m da maré tivesse sido removida por um evento extremo. Assim, considerando uma variação média de maré de cerca de 1,0m tomou-se essa como profundidade mínima a ser cavada no limite inferior do pós-praia. Acima desse ponto adicionou-se o desnível da praia (medido no momento da coleta com Balizas de Emery) à coluna de sedimento retirada com o trado, a qual alcançou $2 \mathrm{~m}$ de profundidade nas regiões mais altas do pós-praia. De fato, algumas amostras complementares ao objetivo 1.2 revelaram que os pellets poderiam ser encontrados até essa profundidade, embora estes se concentrassem no primeiro metro. O sedimento foi coletado e triado conforme exposto anteriormente e os pellets separados e contados. Os dados foram trabalhados de forma a produzir duas estimativas considerando duas variáveis (unidades) diferentes. A primeira considerou o volume da coluna de sedimento amostrada $\left(0,036 \mathrm{~m}^{3}\right)$, calculado para cada amostra considerando a profundidade de $2 \mathrm{~m}$ e o diâmetro do trado $(0,1524 \mathrm{~m})$, e a média gerada pelas amostras realizadas em cada transecto. A segunda, complementar à primeira, levou a uma 
avaliação de abundância (absoluta) para a faixa de praia amostrada, ou seja, por transecto linear (ST - Strip Transect/Transecto Linear; Defeo e Ruenda, 2002). Esse método foi utilizado para corrigir possíveis ruídos devido às diferenças na largura do pós-praia entre as áreas, ao fato dos pellets não distribuírem-se necessariamente ao longo de todo o pós-praia e à possibilidade do padrão de distribuição across-shore dos pellets variar ao longo da praia, fatos não contemplados na primeira estimativa apresentada acima. Este método considera a interpolação do número total de pellets $/ 0,036 \mathrm{~m}^{3}$ obtido em cada amostra ao longo do transecto para o volume total de sedimento possível de ser amostrado no transecto ( $2 \mathrm{~m}$ de profundidade $\mathrm{x}$ 0,1524m de largura), gerando uma estimativa do número absoluto de pellets por uma fatia de 0,1524m de praia perpendicular à linha da água com comprimento equivalente à porção em que os pellets ocorreram. Com essa estimativa foi possível também avaliar a quantidade de pellets na enseada como um todo.

Ao final realizou-se uma análise de variância do tipo I de um fator (área - fator fixo com 15 níveis) seguida do teste SNK para comparações múltiplas a posteriori (Underwood, 1997). Esta análise foi feita separadamente para cada variável calculada $\left(\mathrm{m}^{3}\right.$ e ST).

\section{Calcular a taxa de entrada dos grânulos}

Para estimar a taxa de entrada dos grânulos na praia uma avaliação direcionada à zona de deixa da maré foi realizada em 6 áreas (área - fator fixo com 6 níveis; Figura 8) que foram dispostas de forma eqüidistante ao longo da Enseada de Santos (área 1 a 4 pertencentes a Santos; 5 e 6 a São Vicente). Cada uma destas áreas foi visitada em cada estação do ano (estação - fator fixo com 4 níveis) em 3 períodos de maré baixa de sizígia (período - fator fixo com 3 níveis; Tabela 2). Dez amostras (1.0 x 3.0m cada) superficiais do sedimento (nesta área os grânulos não aparecem soterrados) foram sorteadas ao acaso ao longo de uma faixa de $100 \mathrm{~m}$ no centro da zona de deixa mais elevada da praia. O sedimento foi triado como exposto anteriormente e os grânulos contados e caracterizados. A taxa de entrada dos grânulos na praia foi calculada com base na densidade de pellets (por 1,0 $\mathrm{m}^{2}$ ) por período de coleta. A hipótese nula de que a taxa de entrada dos grânulos não depende da área, da estação do ano e do período da coleta foi testada com uma análise de variância do tipo I de três fatores (Underwood, 1997). 


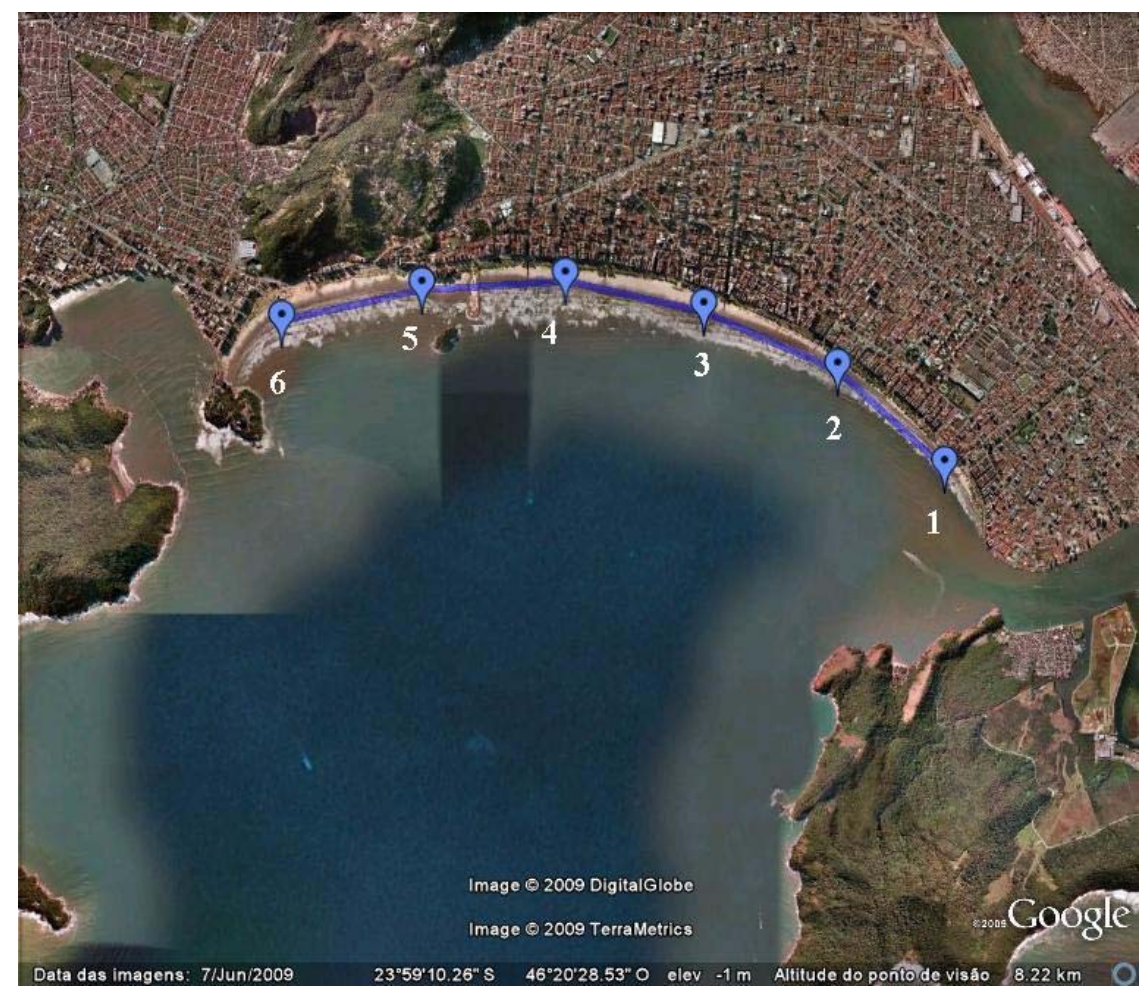

Figura 8. Áreas de coleta para amostragem da taxa de entrada dos grânulos.

Tabela 2. Datas das coletas para análise da taxa de entrada dos pellets.

\begin{tabular}{|c|c|c|c|}
\hline \multicolumn{4}{|c}{ Coletas } \\
\hline Estação & I & II & III \\
\hline Inverno & $11 / 8 / 2008$ & $26 / 8 / 2008$ & $22 / 9 / 2008$ \\
\hline Primavera & $21 / 10 / 2008$ & $24 / 11 / 2008$ & $01 / 12 / 2008$ \\
\hline Verão & $10 / 2 / 2009$ & $14 / 2 / 2009$ & $14 / 3 / 2009$ \\
\hline Outono & $27 / 3 / 2009$ & $04 / 4 / 2009$ & $9 / 4 / 2009$ \\
\hline
\end{tabular}

\section{Descrever as características dos grânulos}

\subsection{Composição Química}

A composição química dos pellets (tipo de polímero)(ver EPA, 1992a) foi determinada para auxiliar na identificação da origem do material. Foram analisados 500 pellets sorteados ao acaso dentre aqueles provenientes da coleta realizada ao longo da praia (objetivo 1.3). Para tanto, dois métodos foram utilizados e comparados entre si. 
Primeiramente os pellets foram separados utilizando-se um método simples e rápido, por imersão em soluções de diferentes densidades (Spinacé e De Paoli, 2005; Figura 9).

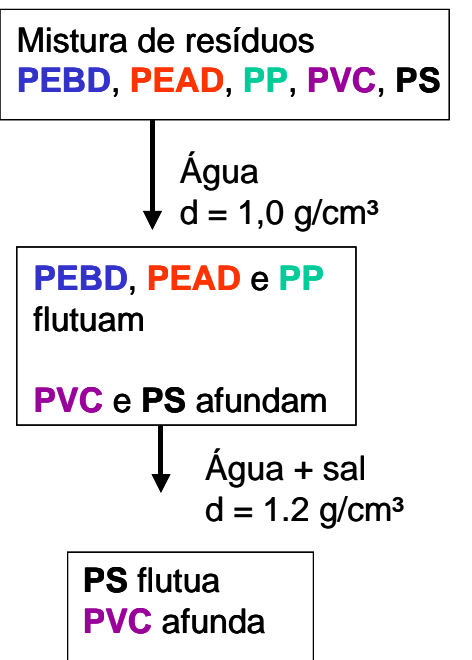

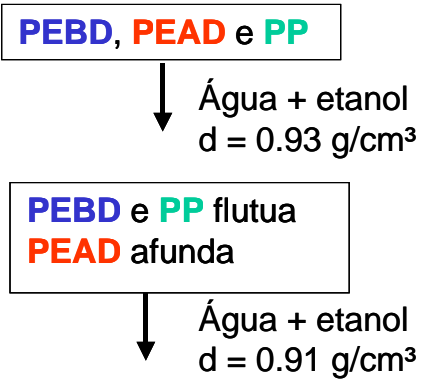

PP flutua
PEBD afunda

Figura 9. Esquema de separação de polímeros por diferença de densidades. PEBD (Polietileno de Baixa Densidade), PEAD (Polietileno de Alta Densidade), PP (Polipropileno), PS (Poliestireno) e PVC (Policloreto de Vinilideno). (Fonte: Spinacé e De Paoli, 2005)

Depois de separados, cada um dos pellets foi encaminhado para o Instituto de Química (IQ) da Universidade de São Paulo para determinação da composição química através de Microscopia Raman (Canevarolo, 2004). As medidas foram realizadas em um Microscópio Raman confocal WITec Alpha 300 R com fonte de luz laser de 532nm (potência máxima 100mW) com componente harmônica em 1046nm (potencia máxima $50 \mathrm{~mW}$ ). Utilizou-se uma área de aproximadamente $0,5 \mu \mathrm{m}^{2}$ para efetuar a aquisição dos espectros Raman. Os pellets foram analisados e agrupados comparando-se os espectros das amostras com os espectros dos padrões de PE e PP (Figuras 10 e 11). Posteriormente esses dados foram comparados com os resultados obtidos na análise de densidade a fim de verificar a concordância entre os dois métodos. 


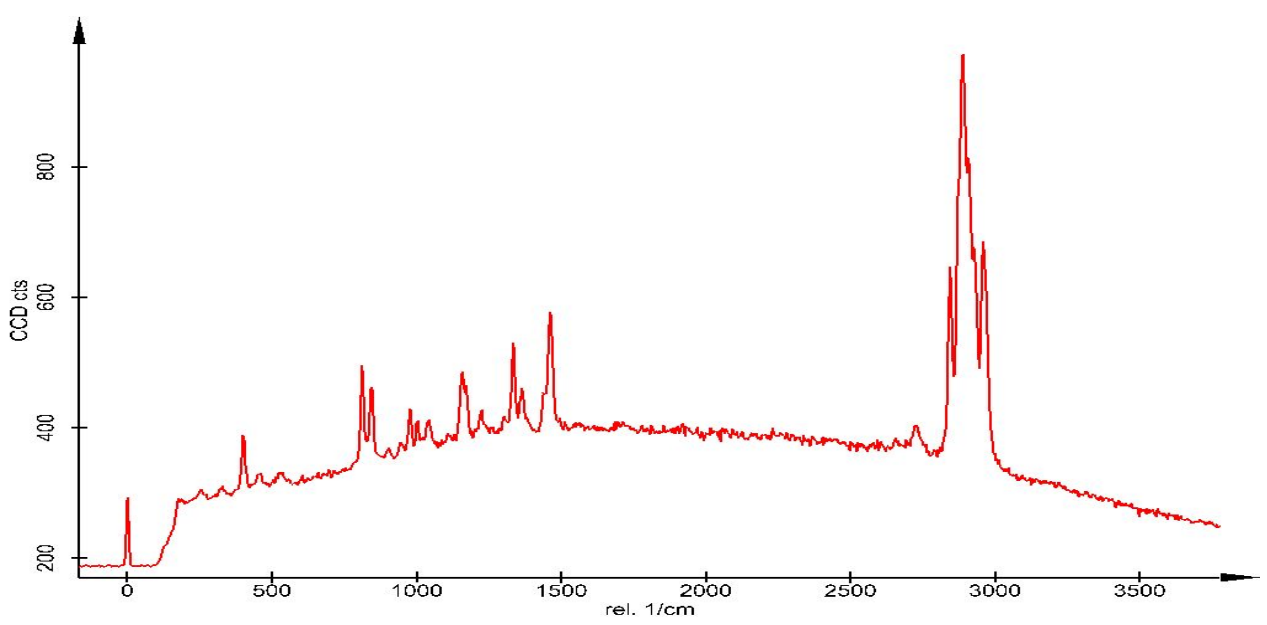

Figura 10. Espectro padrão de polipropileno (PP).

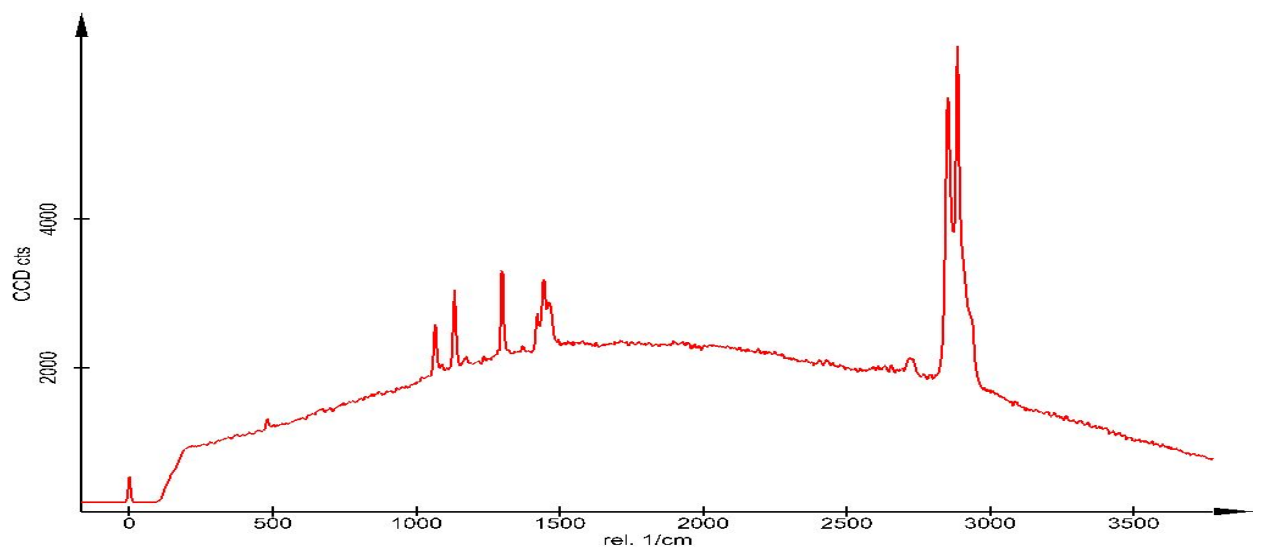

Figura 11. Espectro padrão de polietileno (PE).

\subsection{Caracterização Morfológica}

Essa abordagem buscou fazer basicamente duas análises: uma comparando as características dos pellets encontrados em diferentes profundidades no sedimento e outra caracterizando os pellets coletados na zona de deixa comparando-os entre área e estações do ano. Dentre os pellets coletados no objetivo 1.1 cerca de 500 de cada profundidade (10 intervalos de $10 \mathrm{~cm}$ de profundidade; totalizando 5000) foram escolhidos de forma aleatória e analisados morfologicamente. Caso esse número (500 pellets) não estivesse presente, todos eram analisados. Para a zona de deixa foram analisados 6000 pellets coletados no objetivo 2 (para a análise da taxa de entrada), totalizando 250 pellets por área e por estação do ano. Os grânulos foram analisados quanto à forma, cor, índice de desgaste e tamanho. A forma foi dividida em 8 tipos (Figura 12), de acordo com o observado nos grânulos: esférica achatada, cilíndrica, 
cilíndrica achatada, cúbica, esférica, retangular, retangular achatada e disforme (que não se enquadrava em nenhuma das anteriores). Para a análise da cor (Figura 13) foi utilizada a tabela universal das 256 combinações de RGB (Red/Green/Blue). Já o índice de desgaste foi observado em microscópio estereoscópico e classificado em 5 níveis de porcentagem $(0-20 \%, 20-40 \%, 40-60 \%, 60-80 \%$ e 80-100\%) de rebarbas (“fiapos” na superfície do pellets), incrustação (qualquer tipo de material aderido) e craquelamento (superfície quebradiça). Para todas essas características o teste de qui-quadrado (Zar, 1999) foi utilizado para comparar pellets em diferentes profundidades ou coletados na linha de deixa em diferentes áreas e estações.

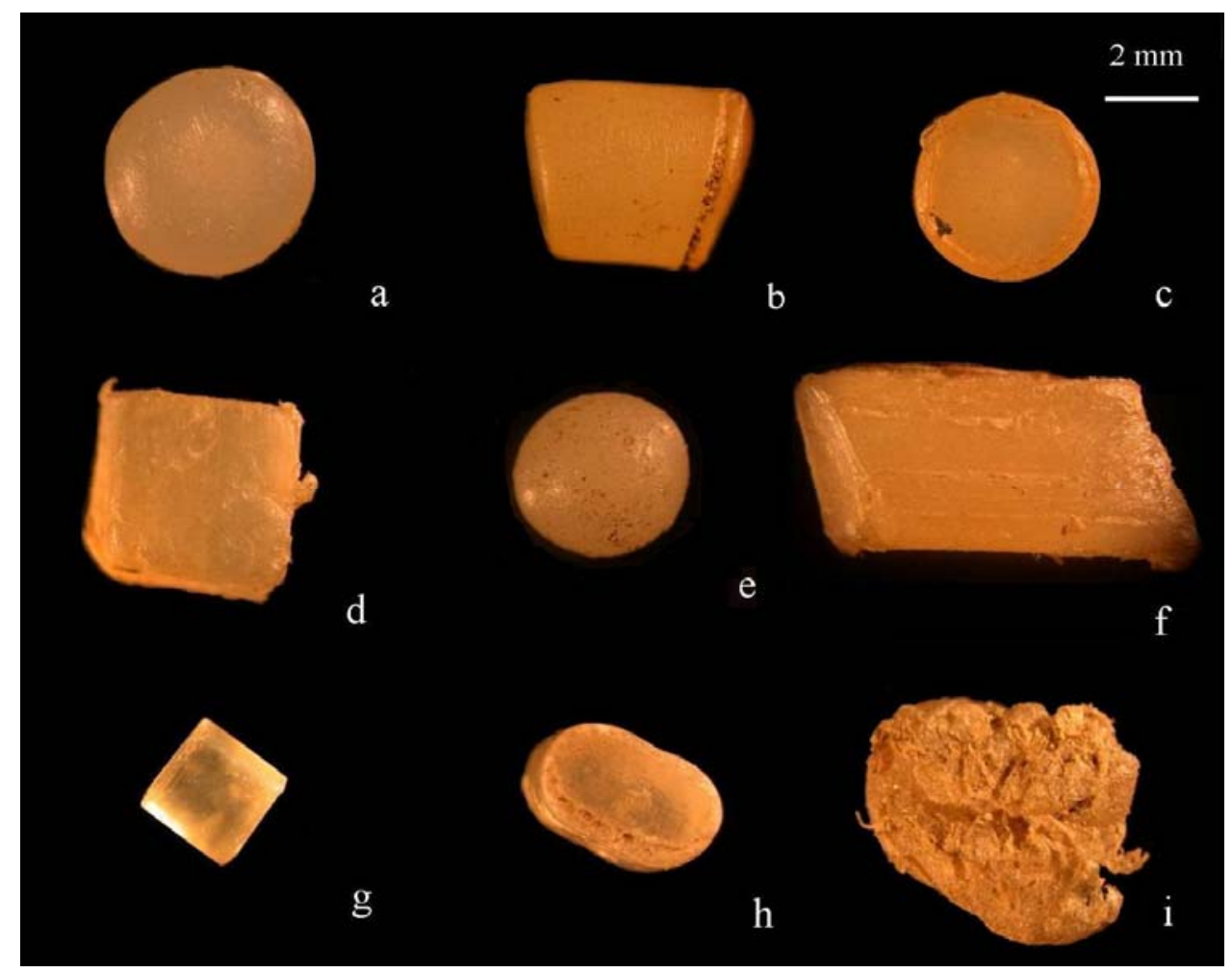

Figura 12. Formas de pellets observados nas praias da Enseada de Santos. a.esférica achatada, b.cilíndrica, c.cilíndrica achatada, d.cúbica, e. esférica, f.retangular, g./h.retangular achatada, i.disforme. 


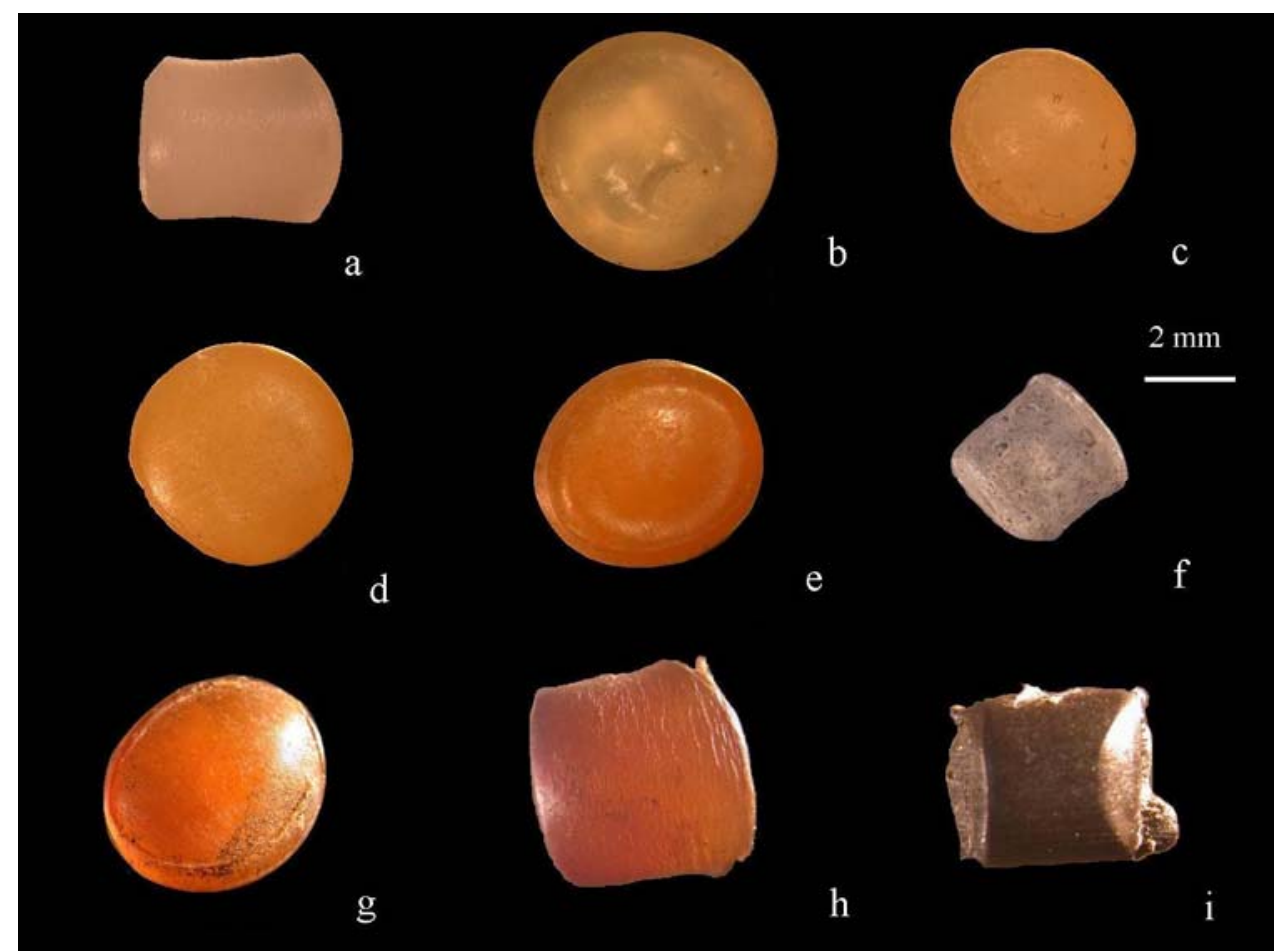

Figura 13. Principais padrões de cores dos pellets coletados nas praias da Enseada de Santos, em RGB (a.30; b.29; c.28; d.25; e.32; f.41; g.204; h.218; i.0).

Para a variável tamanho foram medidos a altura e a largura (diâmetro, para os de formato arredondado) de cada grânulo com o auxílio de um paquímetro digital. Esses dados foram submetidos posteriormente à análises de variância do tipo I de um fator seguidas do teste SNK para comparações múltiplas a posteriori (Underwood, 1997) a fim de verificar diferenças entre as profundidades (fator fixo com 10 níveis). Para fazer comparações entre áreas de coleta (fator fixo com 6 níveis) e estações do ano (fator fixo com 4 níveis) foi utilizada uma ANOVA do tipo I de 2 fatores.

\section{Identificar as possíveis fontes de emissão de grânulos para a Enseada de} Santos

Paralelamente ao trabalho de campo descrito acima foi realizado um levantamento das empresas que produzem, transportam e processam os pellets nas imediações da área de estudo, i.e., na Baixada Santista. Estes dados foram obtidos a partir de consultas a sites de sindicatos, associações e das empresas relacionadas ao setor plástico, além de telefonemas às indústrias e a setores específicos do Porto de Santos. Além disso, foi realizada uma visita à unidade da Braskem, indústria produtora 
de pellets situada em Paulínia, cerca de $100 \mathrm{~km}$ da capital São Paulo. O volume envolvido e o tipo de polímero produzido pelas indústrias foram também levantados para que as possíveis fontes destes grânulos para o ambiente fossem estabelecidas e utilizadas para estudos e abordagens futuras.

Após a realização deste levantamento, foram escolhidos 6 pontos como prováveis fontes de emissão deste material para simular a dispersão dos pellets ao longo de 1 ano. A cada hora foi lançada ao ambiente 1 partícula de cada um dos 6 pontos pelo período de 12 meses (referentes ao ano de 2008), totalizando 8.760 partículas. Essa modelagem foi adaptada a partir da modelagem numérica desenvolvida por Harari e Gordon (2001) para avaliar o grau de dispersão de substâncias e/ou partículas no Estuário de Santos. O modelo hidrodinâmico gerou correntes para todos os meses, cobrindo assim todas as condições de maré (Sizígia e Quadratura) e de ventos (calmaria, ventos predominantes e frentes frias). Como as partículas são lançadas a cada hora, todas as situações hidrodinâmicas ao longo do ano de 2008 foram cobertas. 


\section{RESULTADOS}

\section{Compreender o padrão de distribuição dos grânulos plásticos nas praias}

\section{da Enseada de Santos}

\subsection{Avaliar a distribuição dos grânulos em profundidade no sedimento}

A quantidade de pellets apresentou um evidente decréscimo com a profundidade no sedimento (Figura 14), embora isso não tenha podido ser estatisticamente comprovado (ANOVA: $F=1.35 ; \mathrm{GL}=9 ; \mathrm{p}=0.22$ ) devido ao grande erro padrão das estimativas decorrente da grande variabilidade espacial da distribuição dos pellets na área, fato desconhecido até então. As maiores médias foram observadas nos $30 \mathrm{~cm}$ superiores (cerca de 1.100 pellets $/ 0,1 \mathrm{~m}^{3}$ ), diminuindo a cada nova profundidade, (com exceção de dois aumentos intermediários, nos intervalos de $20-30 \mathrm{~cm}$ e $60-70 \mathrm{~cm}$ ) e finalizando com 32,6 pellets em $90-100 \mathrm{~cm}$.

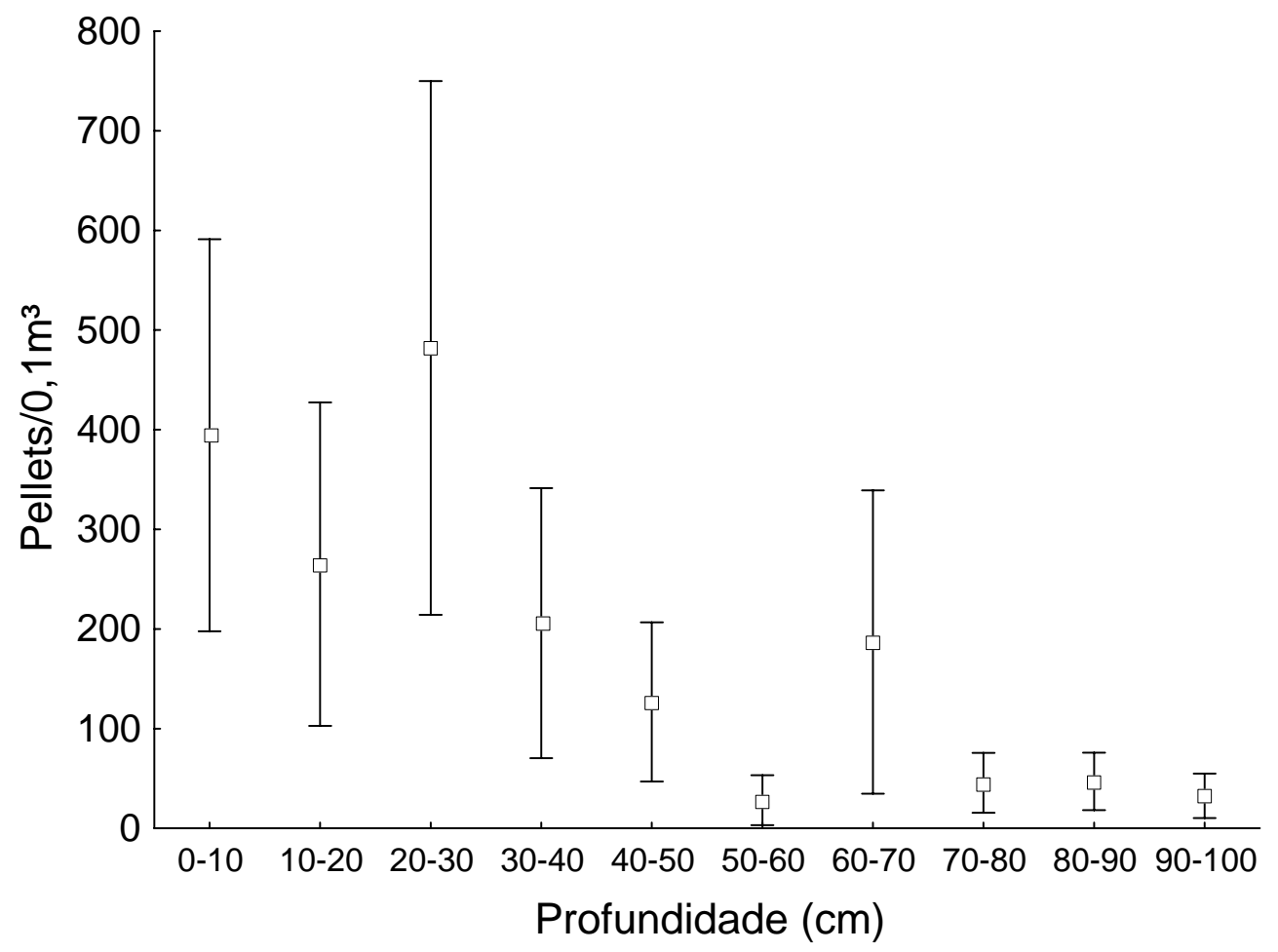

Figura 14. Média e erro padrão do total de pellets por $0.1 \mathrm{~m}^{3}$ a cada intervalo de $10 \mathrm{~cm}$ de profundidade no sedimento $(\mathrm{n}=10)$. 


\subsection{Avaliar a distribuição dos grânulos ao largo da praia (distribuição} vertical)

A hipótese nula de que os grânulos distribuem-se de forma homogênea ao largo da região amostrada foi refutada (ANOVA: $F=91.531 ; G L=11 ; p<0.001$ ), pois os pellets se concentram na região superior da praia. Assim, mesmo na região do supralitoral, a abundância dos pellets diminui à medida que se afasta da parte mais alta da praia em direção ao limite inferior do pós-praia (Figura 15). Na primeira altura foi observada uma densidade média de 136 pellets $/ 0.018 \mathrm{~m}^{3}$, diminuindo gradativamente nas seguintes até o valor de 0.44 pellets $/ 0.018 \mathrm{~m}^{3}$ na distância de $78 \mathrm{~m}$ do calçadão, no limite entre o póspraia e a região entremarés.

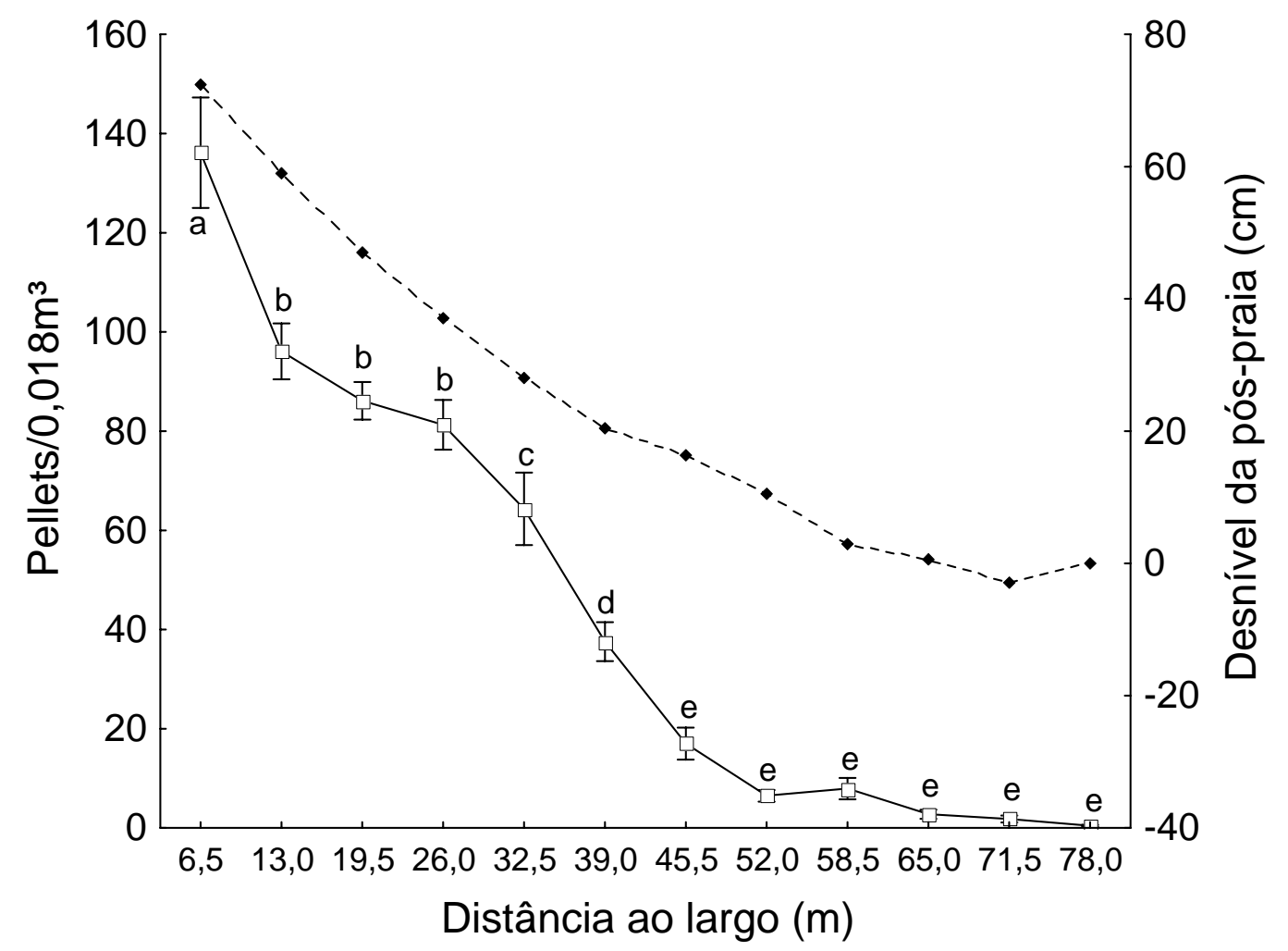

Figura 15. Média e erro padrão do total de pellets por $0,018 \mathrm{~m}^{3}$ a cada intervalo de $6,5 \mathrm{~m}$ ao largo da praia $(n=25)$ em relação à variação do perfil (desnível, cm). As letras sobrescritas representam o resultado do teste SNK (letras idênticas representam diferenças não significativas). 


\subsection{Avaliar a distribuição dos grânulos ao longo da praia (distribuição horizontal)}

O resultado da distribuição horizontal dos pellets referente às 15 áreas está representado nas Figuras 16 (por $0.036 \mathrm{~m}^{3}$ ) e 17 (por Transecto Linear - ST), e o perfil praial de cada uma está apresentado no anexo (Anexo I). Os dados revelaram que houve variação de abundância de pellets ao longo da praia, tanto considerando a densidade em $0.036 \mathrm{~m}^{3}(\mathrm{~F}=23.88 ; \mathrm{GL}=14 ; \mathrm{p}<0.001)$ quanto o número absoluto em $\mathrm{ST} \quad(\mathrm{F}=50.85$; $\mathrm{GL}=14 ; \mathrm{p}<0.001)$. As áreas 2 a 6 apresentaram a maior densidade de pellets, com a média de 82/0.036m³ , chegando à densidade máxima de $139 / 0.036 \mathrm{~m}^{3}$ na área 3. Destaca-se também a última área amostrada, correspondente ao final da enseada (São Vicente), com uma tendência de aumento na densidade de pellets em relação às áreas anteriores (cerca de 22/0.036 $\mathrm{m}^{3}$ ), embora não significativamente diferente das áreas vizinhas. Para o número absoluto (ST) o padrão geral repete-se, com exceção dos picos nas áreas 5 e 6, visivelmente evidenciados pelo teste SNK. Essa diferença deve-se à maior largura do pós-praia nestas áreas, levando portanto, à uma maior estimativa da abundância de pellets por trecho perpendicular de praia. Com esse dado fica mais evidente o aumento da quantidade de pellets na área 15, embora este ainda permaneça não significativo.

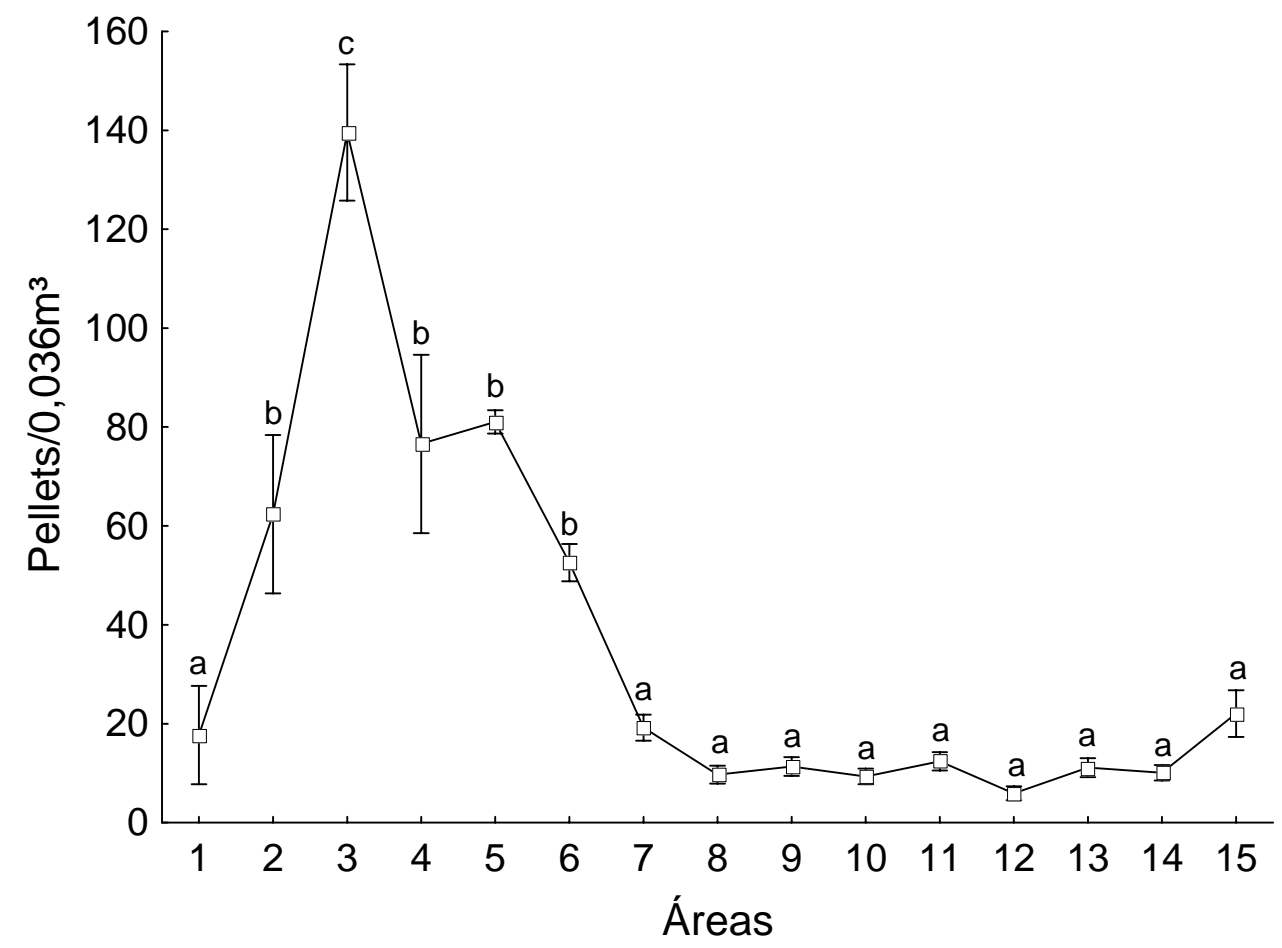


Figura 16. Média e erro padrão do número de pellets por $0,036 \mathrm{~m}^{3}$ a cada área da amostragem ao longo da praia $(n=3)$. As letras sobrescritas representam o resultado do teste SNK (letras idênticas representam diferenças não significativas).

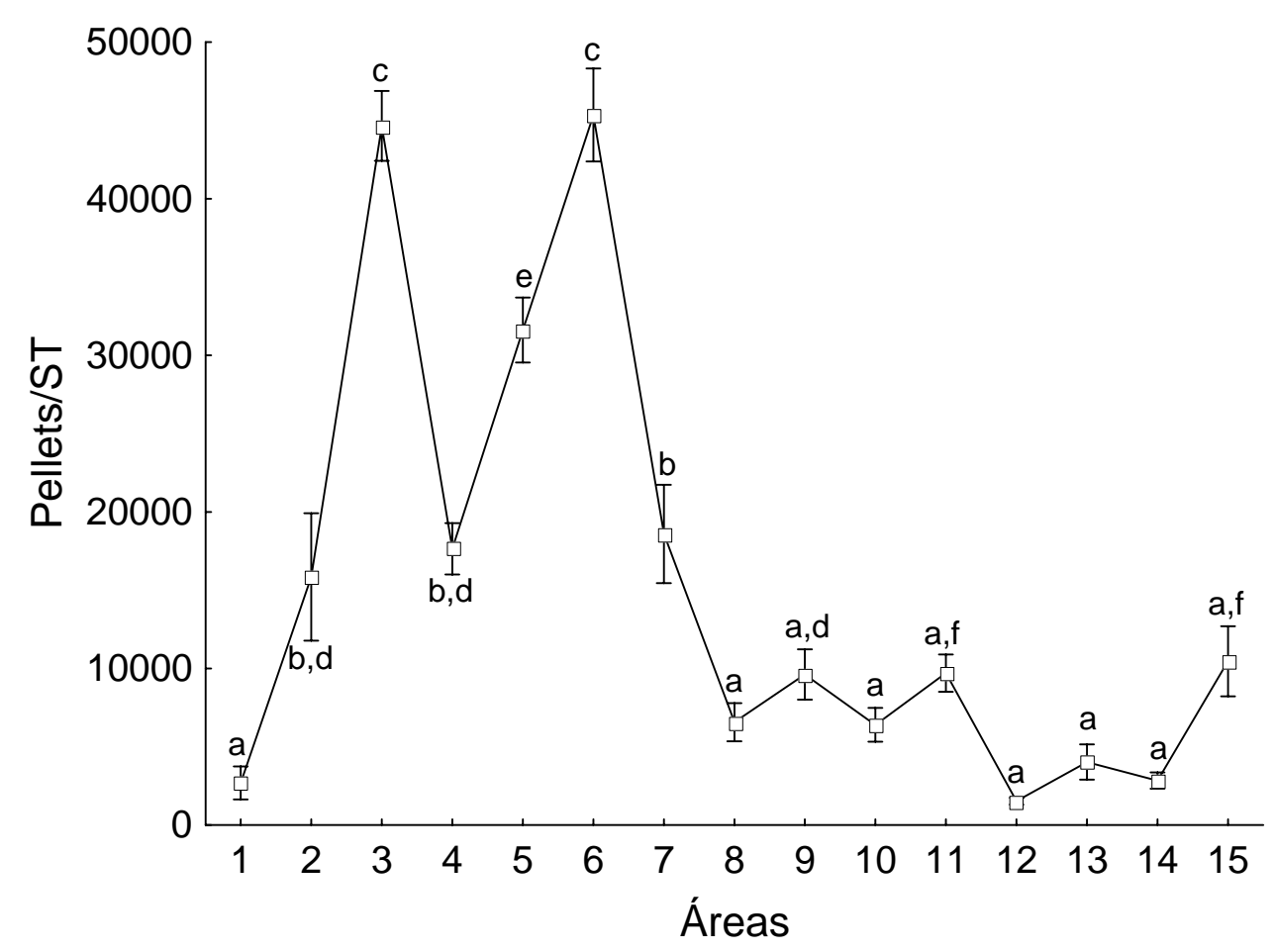

Figura 17. Média e erro padrão do número de pellets por ST (ST - "Strip Transect”/Transecto Linear) a cada área da amostragem ao longo da praia. As letras sobrescritas representam o resultado do teste SNK (letras idênticas representam diferenças não significativas).

Interpolando o número de pellets coletados nessa amostragem, considerando distribuição ao longo da praia (entre áreas), ao largo da praia (entre amostras coletadas ao longo de cada transecto) e em profundidade no sedimento (entre as diferentes pegadas de $20 \mathrm{~cm}$ ), confirmou-se que há uma maior concentração nas menores profundidades, nas regiões mais distantes da linha d’água e nas áreas mais próximas ao Porto de Santos (de 500 a 2000m do Canal)(Figuras 18 e 19). 


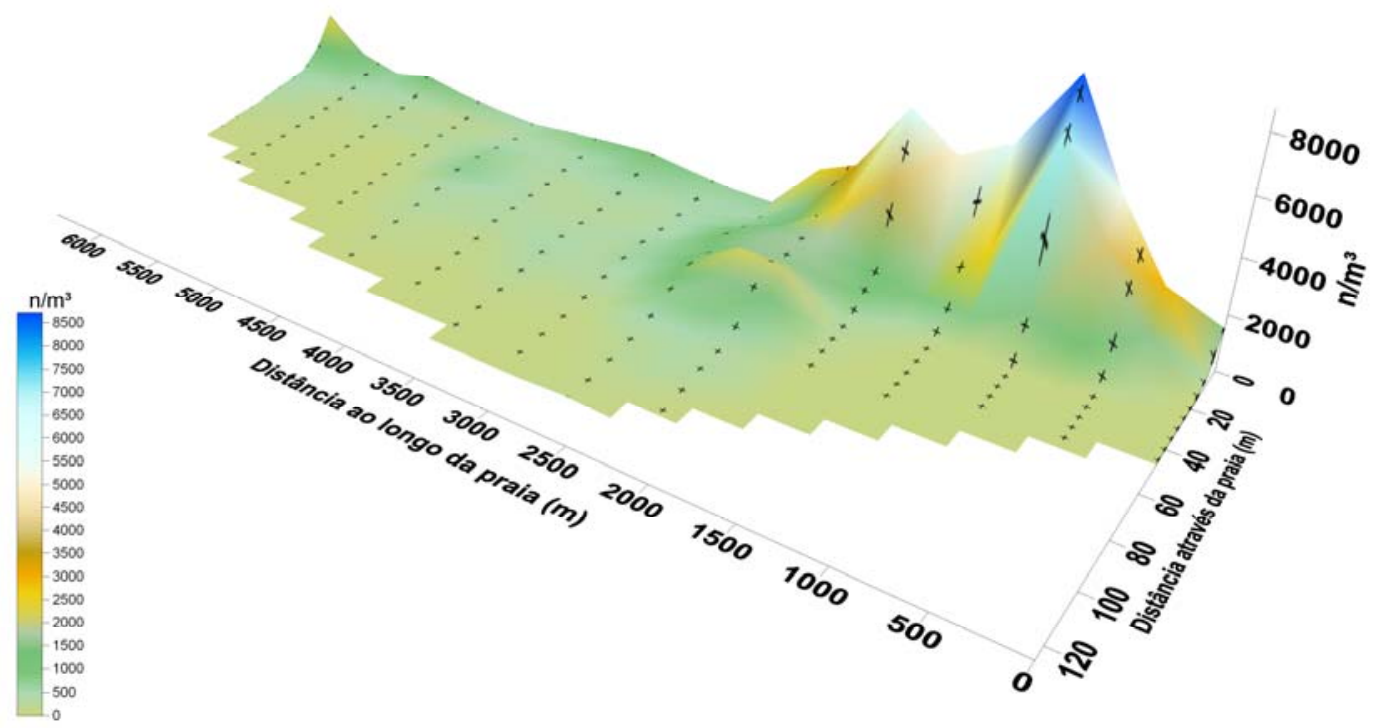

Figura 18. Média do número de pellets por $1 \mathrm{~m}^{3}$ na coluna de sedimento $(0$ a $2.0 \mathrm{~m})$ em relação às distâncias ao longo (15 áreas) e ao largo da praia (0 a 120m). Os pontos realçam as amostras eqüidistantes realizadas em cada área. 


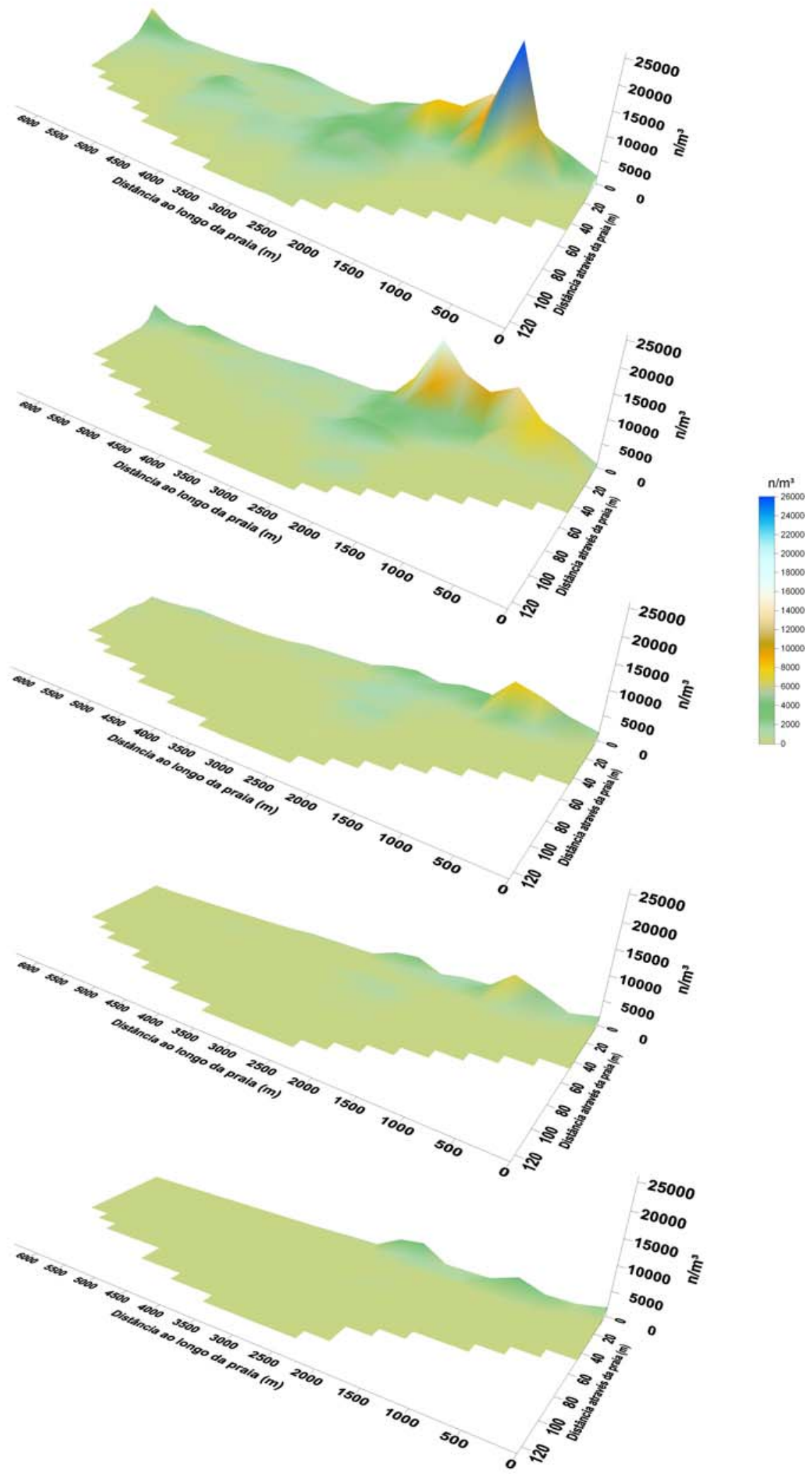

Figura 19. Número de pellets por $1 \mathrm{~m}^{3}$ em cinco classes de profundidade no sedimento (respectivamente, de cima para baixo: 0-0,4; 0,4-0,8; 0,8-1,2; 1,2-1,6; 1,6-2,0) em relação às distâncias ao largo $(n=10)$ e ao longo da praia $(n=15)$. 


\section{Calcular a taxa de entrada dos grânulos nesta área}

A hipótese nula de que a taxa de entrada dos grânulos não depende da área, da coleta e da estação do ano foi refutada com uma análise de variância (Tabela 3). Os valores significativos para as interações indicam que a variação da abundância de pellets entre as estações do ano dependem da área e do período de coleta e que a variação entre os períodos de coleta depende da área. Esses dados indicam que não há um padrão claro de deposição desses pellets na linha de deixa, pelo menos na escala temporal e espacial analisada. A variação da densidade de pellets nas 3 coletas realizadas nas 6 áreas amostrados para cada estação do ano está representada na Figura 20. A variação máxima encontrada foi de 1 a 377/m².

Verificou-se uma certa homogeneidade entre as áreas no Inverno de 2008, variando de 5 a 15 pellets por $\mathrm{m}^{2}$, com exceção da coleta III, que apresentou um número bem mais elevado em relação às anteriores (cerca de $100 / \mathrm{m}^{2}$ ). Os resultados da taxa de entrada dos grânulos referentes às amostragens da Primavera de 2008 mostraram novamente uma certa homogeneidade entre as áreas, variando principalmente de 2 a 8 pellets por $\mathrm{m}^{2}$, com exceção para a coleta I em cada uma, que apresentou um número bem mais elevado em relação às anteriores (cerca de $13 / \mathrm{m}^{2}$ ). Também se destaca o pico na coleta III da área 4, com um total de 36 pellets por $\mathrm{m}^{2}$. Comparando estas duas estações, pode-se visualizar uma discrepância no número de pellets $/ \mathrm{m}^{2}$, menor na Primavera.

No Verão de 2008/2009 verificou-se novamente uma certa homogeneidade na enseada (em torno de 25 pellets $/ \mathrm{m}^{2}$ ), embora exista a ocorrência de áreas com 3 e outras com 58 pellets $/ \mathrm{m}^{2}$. Salienta-se a maior quantidade na coleta II, que apresentou um número médio mais elevado em relação às anteriores. Os resultados da taxa de entrada dos grânulos referentes às amostragens do Outono de 2009 mostraram que neste período houve uma maior discrepância entre as áreas, variando desde 0,8 até 15 pellets $/ \mathrm{m}^{2}$, fato não observado para a coleta II na qual, devido ao fato da maré estar 'virada' naqueles dias, houve um significativo aporte de grânulos para a linha de deixa. Destaca-se ainda o menor número de pellets encontrados na coleta I de cada área, com exceção da área 1 , que apresentou um total de 14,8 pellets $/ \mathrm{m}^{2}$. 
Tabela 3. Análise de variância do tipo I de três fatores para analisar a variação na quantidade de pellets em função da estação do ano, período de coleta e área amostrada.

\begin{tabular}{|c|c|c|c|c|}
\hline Efeito & GL & MS & F & p \\
\hline Intercepto & 1 & 388476.80 & 1066.50 & $<0,001$ \\
\hline Estação & 3 & 28662.50 & 78.69 & $<0,001$ \\
\hline Coleta & 2 & 46982.30 & 128.98 & $<0,001$ \\
\hline Área & 5 & 4067.00 & 11.16 & $<0,001$ \\
\hline Estação*Coleta & 6 & 54522.60 & 149.68 & $<0,001$ \\
\hline Estação*Área & 15 & 2832.70 & 7.78 & $<0,001$ \\
\hline Coleta*Área & 10 & 2724.20 & 7.48 & $<0,001$ \\
\hline Estação*Coleta*Área & 30 & 3993.10 & 10.96 & $<0,001$ \\
\hline Erro & 648 & 364.30 & & \\
\hline
\end{tabular}
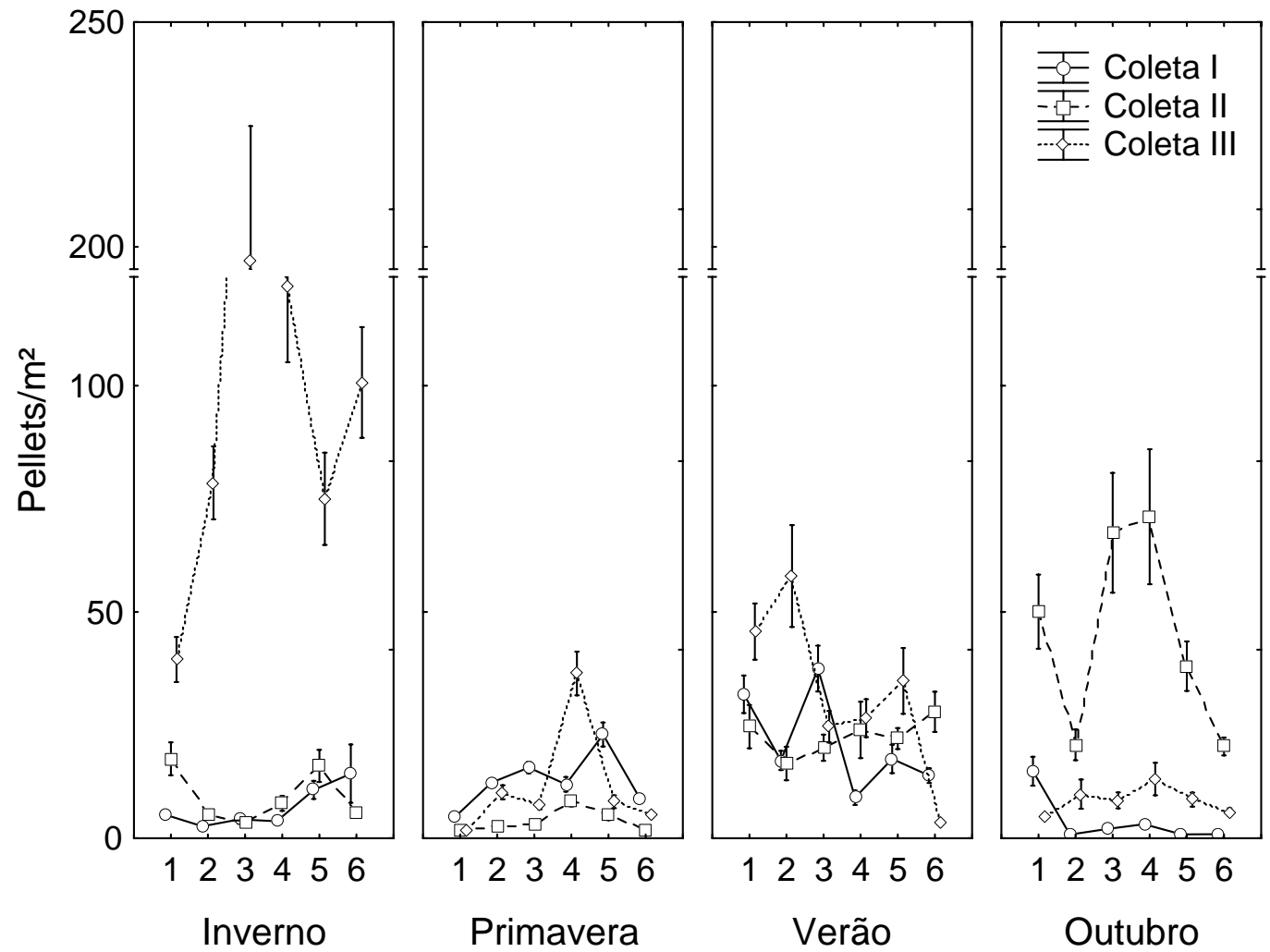

Figura 20. Média e erro padrão do total de pellets por $\mathrm{m}^{2}$ encontrados na linha de deixa nos 3 períodos de coleta realizados para cada uma das 6 áreas amostrados ao longo das estações do ano. 


\section{Descrever a característica dos grânulos}

\subsection{Composição Química}

Os resultados da composição química dos pellets serão aqui apresentados a partir de comparações entre os métodos de densidade e de Microscopia Ramam (Tabela 4). A análise da composição química dos pellets baseada no método da densidade apontou que, dos 500 pellets analisados, 19,4\% eram compostos por Polipropileno (PP; n=97), 24,4\% por Polietileno de Alta Densidade (PEAD; $n=122$ ) e 56,2\% por Polietileno de Baixa Densidade (PEBD; n=281). Com relação à análise por Microscopia Ramam, desenvolvida no Instituto de Química da USP, esta amostra de 500 pellets apresentou as seguintes porcentagens dos 3 tipos de polímeros encontrados: 18\% de PP ( $\mathrm{n}=90$ ), 78.2\% de PE (nessa análise não foi possível separar PEAD e PEBD; $n=391$ ) e 3.8\% de uma mistura entre estes dois polímeros $(n=19)$. Espectros de algumas amostras analisadas de cada uma dessas 3 composições estão apresentados nas figuras 21, 22 e 23, respectivamente.

Tabela 4. Comparação entre os métodos de densidade e Microscopia Ramam na análise da composição química de 500 pellets. Os polímeros encontrados foram Polipropileno (PP), Polietileno de Alta Densidade (PEAD), Polietileno de Baixa Densidade (PEBD) e mistura de PP e PE.

\begin{tabular}{|c|c|c|c|}
\hline Polímero & Densidade & Ramam & Erro \\
\hline PP & $97(19,4 \%)$ & $90(18,0 \%)$ & $20(20,6 \%)$ \\
\hline PEAD & $122(24,4 \%)$ & & \\
\hline PEBD & $281(56,2 \%)$ & $391(78,2 \%)$ & $13(3,2 \%)$ \\
\hline Mistura de PP e PE & - & $19(3,8 \%)$ & $19(3,8 \%)$ \\
\hline Total & 500 & 500 & $52(10,4 \%)$ \\
\hline
\end{tabular}

É importante ressaltar que o erro entre as duas classificações não pode ser medido apenas pela diferença entre o total de pellets classificados em cada tipo de composição, e sim pela soma do número daqueles classificados de maneira incorreta. Das 97 amostras classificadas como PP pelo método de densidade, 20 apresentaram 
espectro semelhante ao padrão de PE, e conseqüentemente, 77 amostras com o espectro semelhante ao padrão PP. Assim, pode-se afirmar que cerca de $21 \%$ das amostras foram classificadas de forma incorreta. O restante das amostras haviam sido classificadas pelo método da densidade como PE (122 PEAD e 281 PEBD). Comparando-se os espectros Raman das amostras com o dos padrões verificou-se que dentre as 403 amostras 13 apresentaram padrão espectral similar ao do PP (figura 10) e 19 amostras apresentaram um padrão espectral que indica uma mistura de PP e PE (Figura 23). Portanto, a taxa de erro foi de cerca de 3,2\% e 3,8\%, respectivamente. De uma maneira geral, dos 500 pellets amostrados, a análise de densidade classificou erroneamente 52, resultando em um erro geral de 10,4\%, e de 6,6\% caso não fosse considerado o erro dos polímeros de mistura (já que não é possível detectá-los pelo método de densidade).

Destacam-se dois pellets que na análise Ramam foram classificados como PP mas que na análise de densidade foram identificados como PE. Esse erro pode ser explicado pelo comportamento atípico destes pellets, que flutuaram na solução de $0,9311 \mathrm{~g} / \mathrm{cm}^{3}$ e afundaram na solução de $0,9095 \mathrm{~g} / \mathrm{cm}^{3}$, porém não até o fim como os outros, ficando mais na superfície do líquido (quase flutuando, comportamento de PP). Esse comportamento pode indicar a presença de alguma substância que aumentou a densidade desses pellets, como incrustações de materiais inertes (sedimento).

Somente a análise por Raman detecta a mistura de polímeros, entretanto a classificação dos PEs em PEAD e PEBD não é possível de ser realizada por esse método. De 19 pellets classificados como Mistura por Raman, 7 foram classificados pela análise de densidade como PEAD, 12 como PEBD e nenhum como PP.

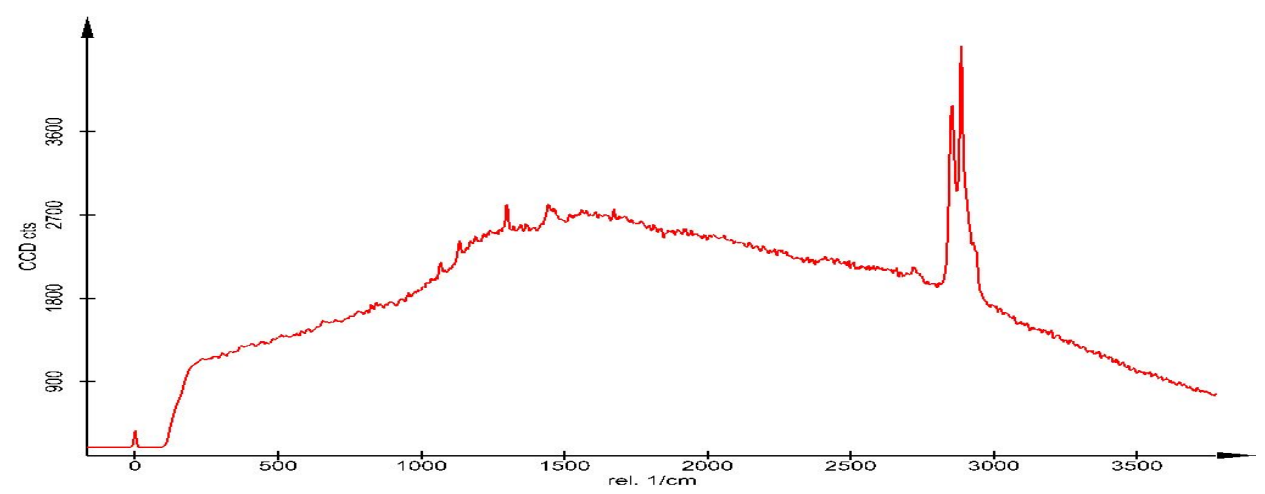

Figura 21. Espectro de uma das amostras de polietileno (PE). 


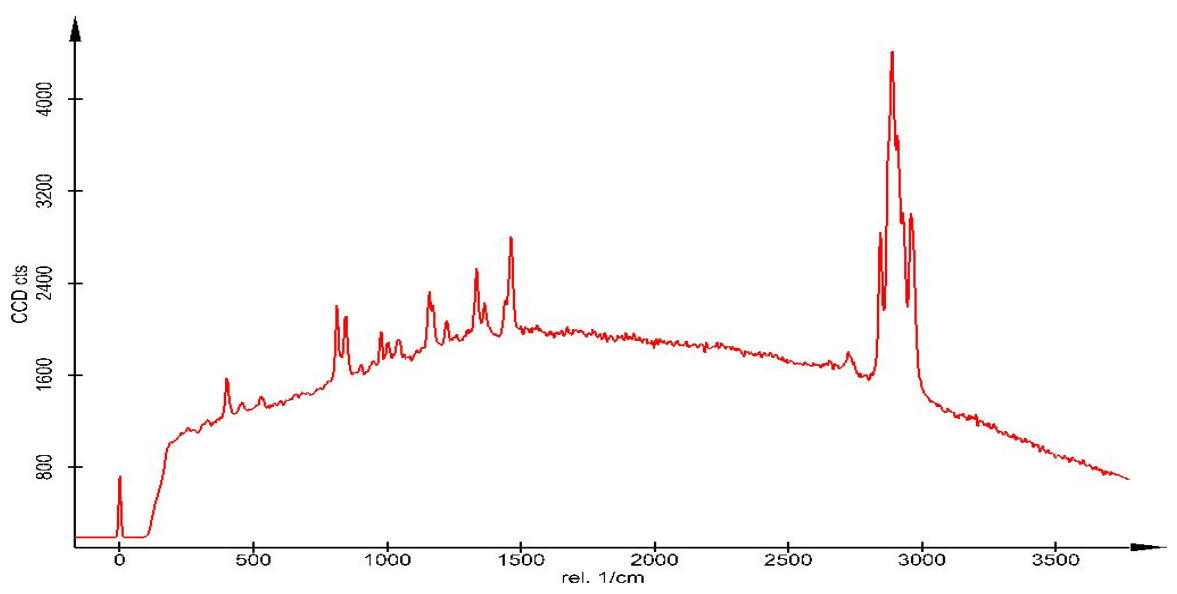

Figura 22. Espectro de uma das amostras de polipropileno (PP).

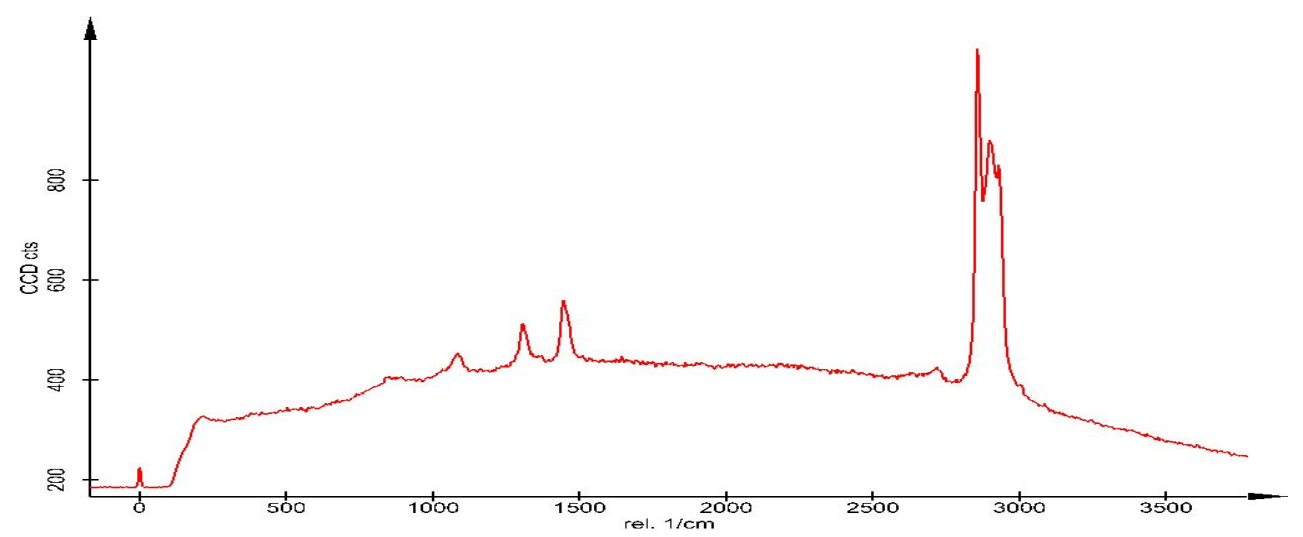

Figura 23. Espectro de uma das amostras consideradas como mistura de polietileno (PE) e polipropileno (PE).

\subsection{Caracterização morfológica em relação à profundidade no sedimento}

A variação da altura dos pellets por profundidade concentrou-se em torno de 2,5 a 3,0mm e está representada na figura 35. O resultado da ANOVA mostrou que há diferença significativa na altura dos pellets entre as diferentes profundidades ( $\mathrm{F}=31.84$; $\mathrm{GL}=9 ; \mathrm{p}<0.001)($ Figura 24), com os pellets mais altos sendo encontrados nas profundidades de $30-40 \mathrm{~cm}$ e $60-70 \mathrm{~cm}$. 


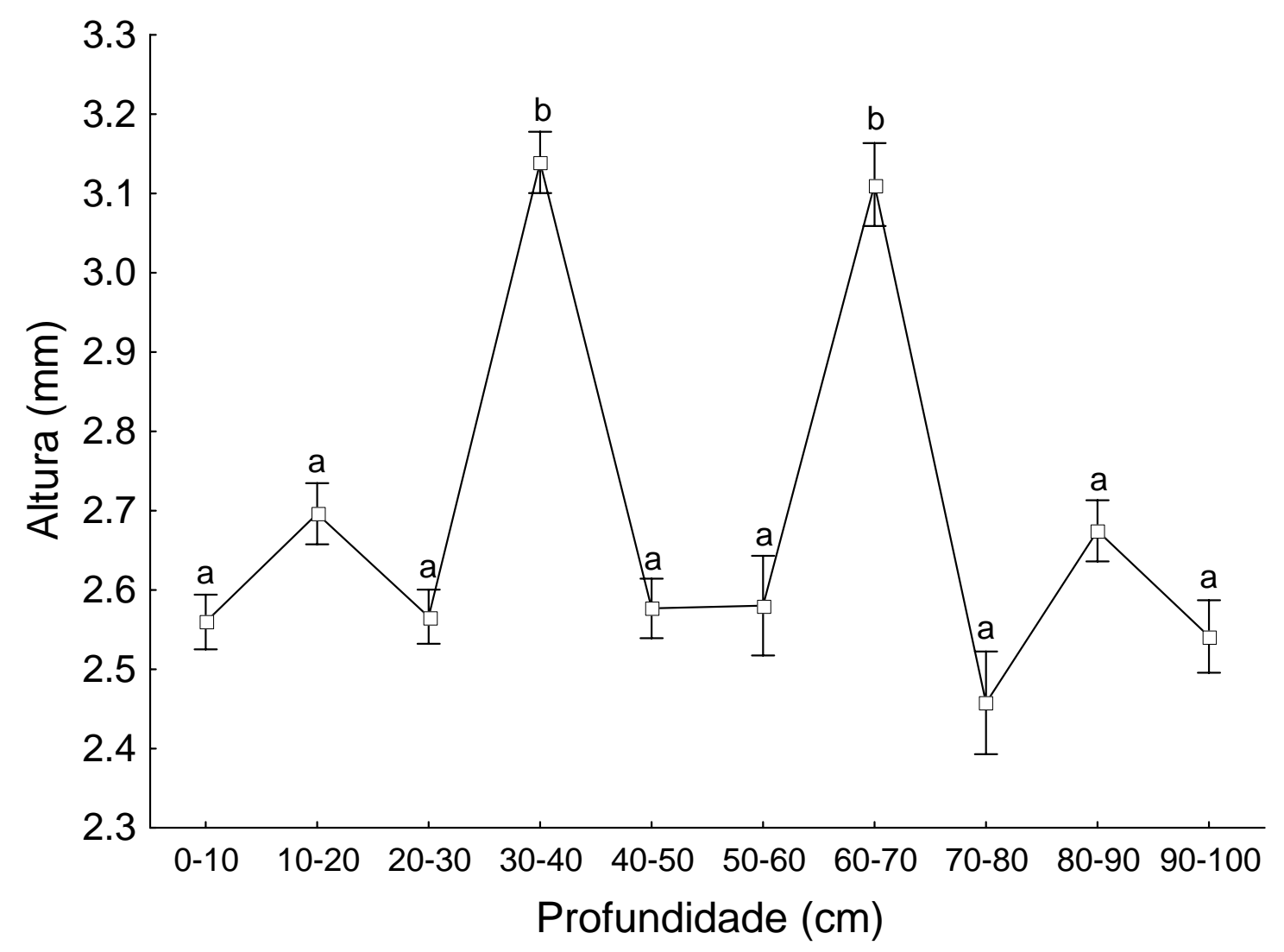

Figura 24. Média e erro padrão da altura dos pellets a cada intervalo de $10 \mathrm{~cm}$ de profundidade no sedimento nas praias da Enseada de Santos. As letras sobrescritas representam o resultado do teste SNK (letras idênticas representam diferenças não significativas).

A distribuição de freqüência de alturas, dividida em intervalos de $0,5 \mathrm{~mm}$, por profundidade amostrada está representada na figura 25, onde também se observa a quantidade de pellets examinados (n), a média (X, em mm) e o desvio padrão das estimativas. 

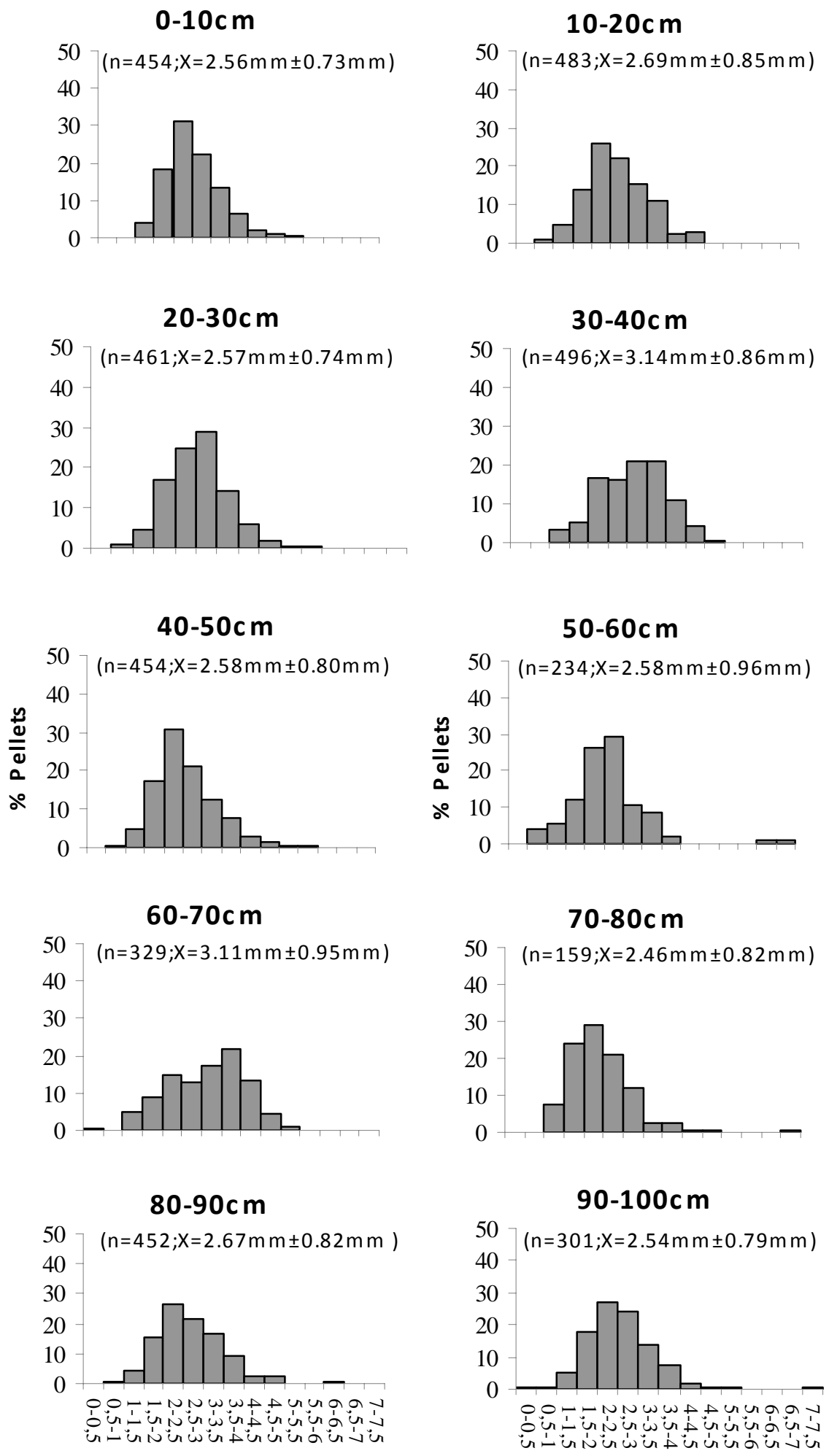

Altura (mm)

\section{Altura (mm)}

Figura 25. Distribuição de freqüência da altura dos pellets em intervalos de profundidade de $10 \mathrm{~cm}$ no sedimento ( $\mathrm{n}=$ número de pellets analisados, $\mathrm{X}=$ =média \pm desvio padrão). 
A variação do diâmetro dos pellets por profundidade concentrou-se em torno de 3.4 a $3.7 \mathrm{~mm}$ e está representada na figura 38. O resultado da ANOVA apresentou que há diferença significativa entre o diâmetro dos pellets nas diferentes profundidades ( $F=35.80 ; G L=9 ; p<0.001)(F i g u r a ~ 26)$, com os pellets com menor diâmetro sendo encontrados entre $30-40 \mathrm{~cm}$ no sedimento. A porcentagem de pellets em cada medida de diâmetro, dividida em intervalos de $0,5 \mathrm{~mm}$, por profundidade amostrada, está representada na figura 27 , onde também se observa a quantidade de pellets examinados (n), a média (X, em mm) e o desvio padrão das estimativas.

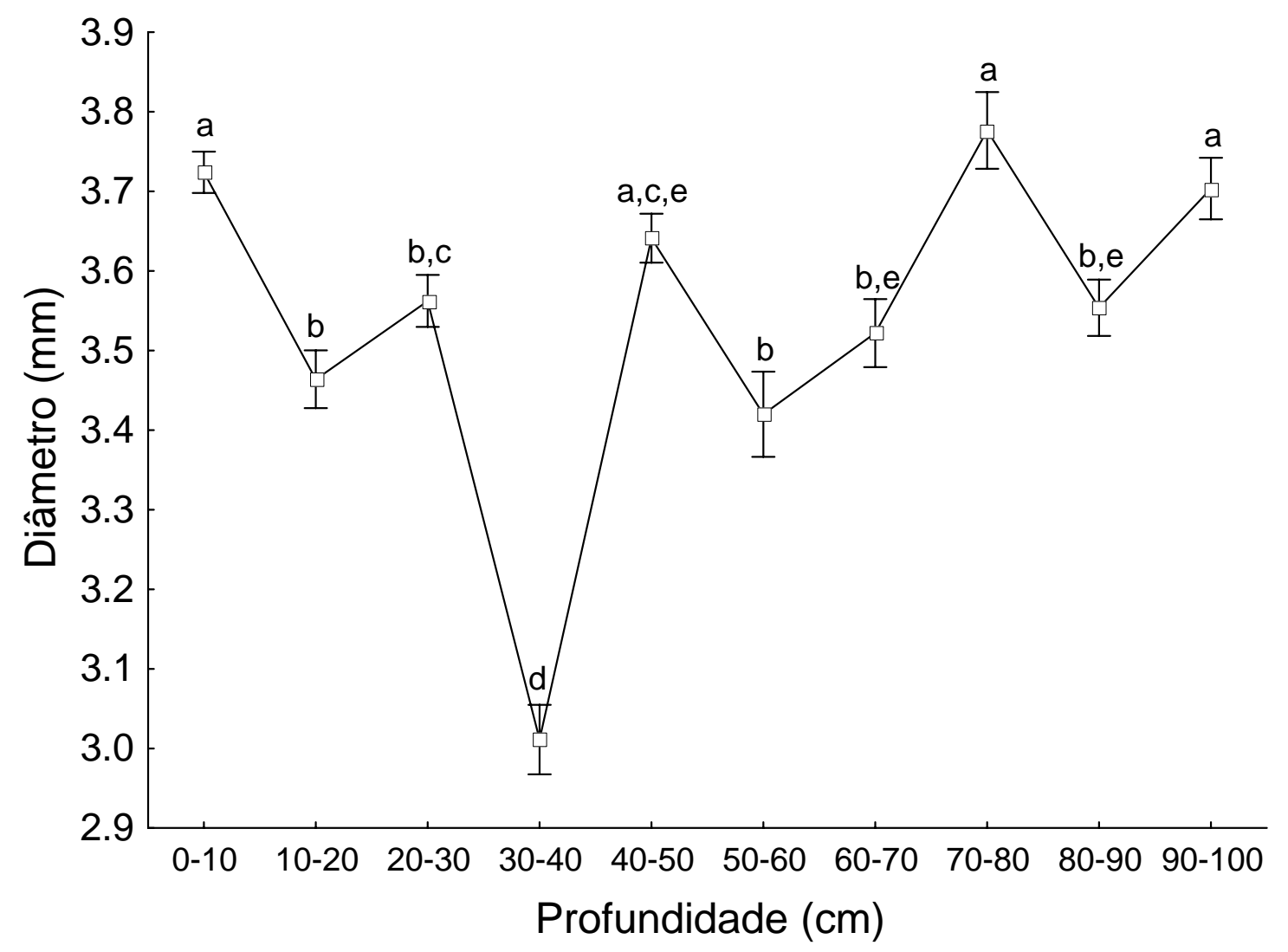

Figura 26. Média e erro padrão do diâmetro dos pellets a cada intervalo de $10 \mathrm{~cm}$ de profundidade no sedimento nas praias da Enseada de Santos. As letras sobrescritas representam o resultado do teste SNK (letras idênticas representam diferenças não significativas). 
$0-10 \mathrm{~cm}$

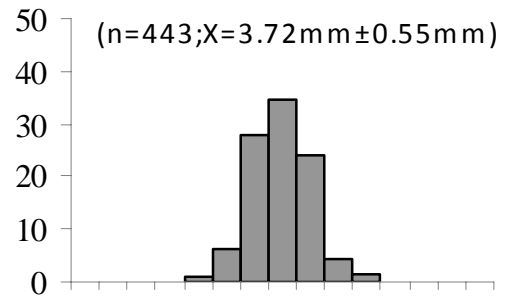

20-30c m

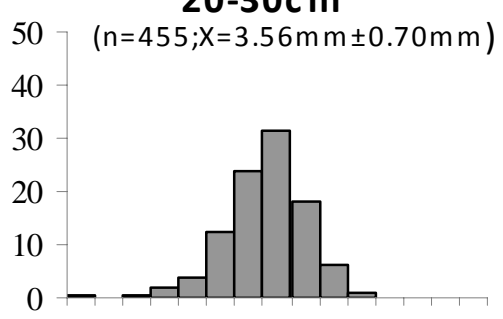

$40-50 \mathrm{~cm}$

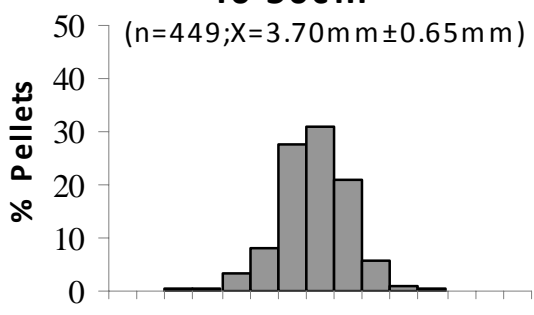

$60-70 \mathrm{~cm}$

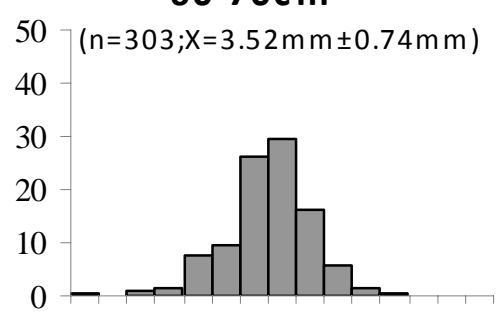

$80-90 \mathrm{~cm}$

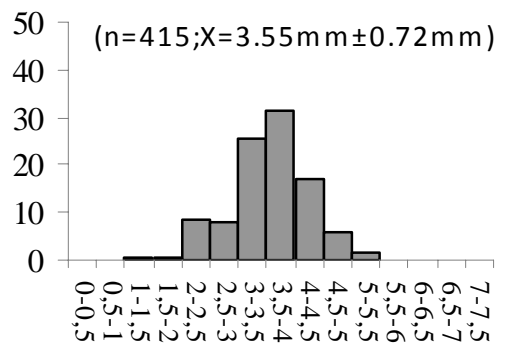

Diâmetro (mm)
$10-20 \mathrm{~cm}$

$50-(\mathrm{n}=479 ; X=3.46 \mathrm{~m} \mathrm{~m} \pm 0.79 \mathrm{~mm})$

40

30

20

10

0

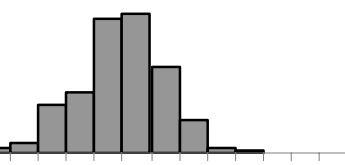

$30-40 \mathrm{~cm}$

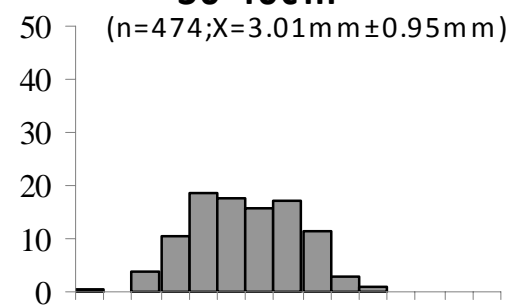

$50-60 \mathrm{~cm}$

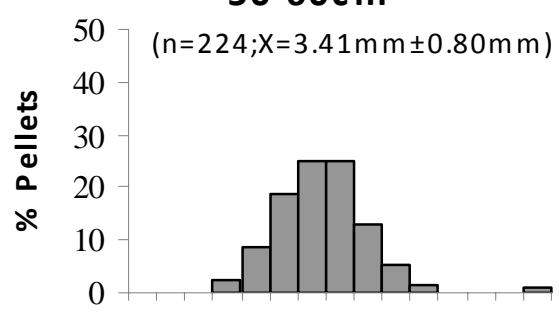

$70-80 \mathrm{~cm}$

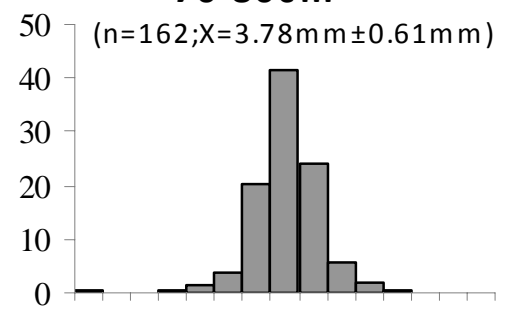

$90-100 \mathrm{~cm}$

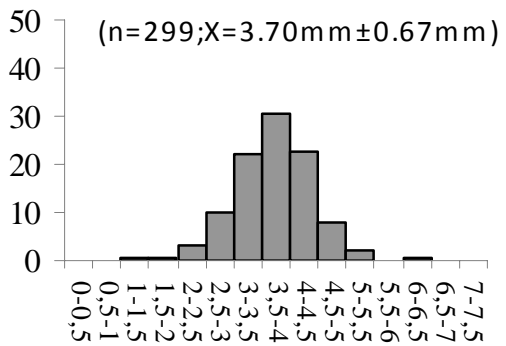

Diâmetro $(\mathrm{mm})$

Figura 27. Distribuição de frequiência do diâmetro dos pellets em intervalos de profundidade de $10 \mathrm{~cm}$ no sedimento ( $\mathrm{n}=$ número de pellets analisados, $\mathrm{X}=$ =média \pm desvio padrão). 
O teste do qui-quadrado apresentou diferença significativa entre a forma dos pellets nas profundidades $\left(\mathrm{X}^{2}=408.72 ; \mathrm{GL}=54 ; \mathrm{p}<0.001\right)$. A maioria foi classificada como cilíndrico e achatado (cerca de 70-90\%) e cerca de 5-10\% como esférico e achatado (Figura 28).

Destacam-se nesta variável os pellets encontrados na profundidade de $30-40 \mathrm{~cm}$ que, apesar de quase 95\% terem sido classificados como cilíndrico-achatado, os dados de altura e diâmetro contradizem tal informação, evidenciando que nesta profundidade os pellets são maiores em altura (Figura 25) e menores em diâmetro (Figura 27), características típicas da forma cilíndrica. Tal aparente contradição pode ser explicada pelo fato de que, apesar de apresentarem um padrão de diâmetro menor, tais pellets ainda podem ter o formato cilíndrico, e ainda que, apesar de apresentarem altos valores em altura, ainda eram considerados achatados em relação aos pellets considerados cilíndricos.

A coloração dos pellets também não variou muito, apesar do teste do quiquadrado ter indicado existir uma diferença significativa entre profundidades $\left(X^{2}=456.61 ; G L=117 ; \mathrm{p}<0.001\right)$ (Figura 29). Cerca de 60\% apresentou um padrão de cor em tons de amarelo claro (principalmente as cores referentes aos códigos 28, 29, 30 e 41), e o restante em tons de marrom-alaranjado (referente ao códigos 204, 217 e 218). Para análise de abundância relativa, nem todas as cores encontradas foram consideradas, sendo apenas aquelas que apresentaram uma porcentagem considerável de pellets (no mínimo 2\% computadas). Pellets pigmentados foram escassos (menos de 5\% em conjunto).

Apesar de o teste do qui-quadrado apresentar diferença significativa no grau de incrustação ( $\left.X^{2}=493.99 ; G L=36 ; p<0.001\right)$, rebarba $\left(X^{2}=299.08 ; G L=36 ; p<0.001\right)$ e craquelamento $\left(\mathrm{X}^{2}=387.33 ; \mathrm{GL}=36 ; \mathrm{p}<0.001\right)$ dos pellets, não foi observado um padrão claro para a variação com a profundidade. A maior parte dos pellets mostrou-se relativamente preservada, com baixos índices de incrustações, rebarbas e craquelamento, conforme as figuras 30, 31 e 32. Em todas as profundidades, mais de 80\% dos pellets apresentaram índices em até 40\% de rebarba e craquelamento em suas superfícies e, em praticamente todas as profundidades, mais de $70 \%$ dos pellets mostraram-se estar abaixo dos $20 \%$ de craquelamento. A porcentagem de pellets com material incrustante foi um pouco menor, com mais de $60 \%$ deles apresentando índices de até $40 \%$. 


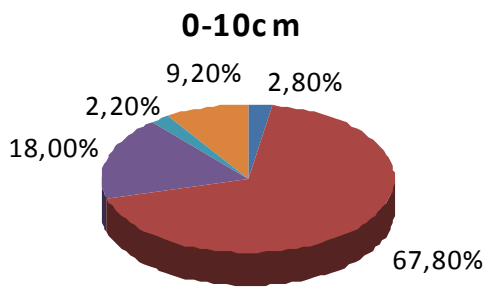

$20-30 \mathrm{~cm}$

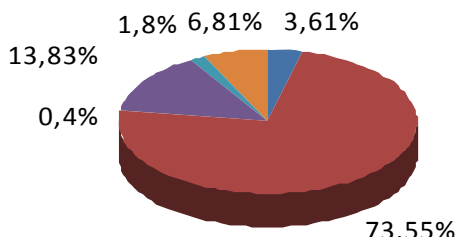

$40-50 \mathrm{~cm}$

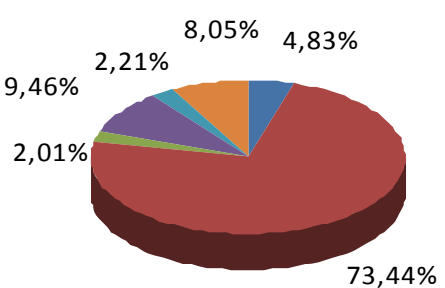

$60-70 \mathrm{~cm}$

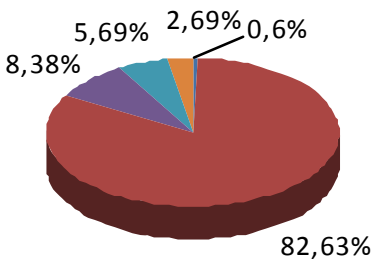

$80-90 \mathrm{~cm}$

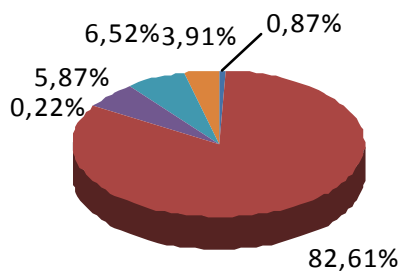

$10-20 \mathrm{~cm}$

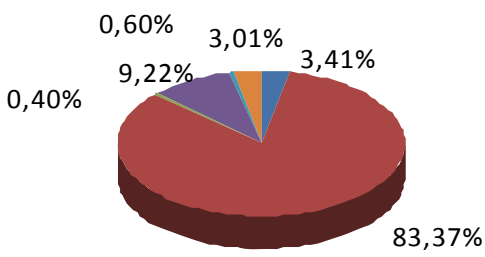

$30-40 \mathrm{~cm}$

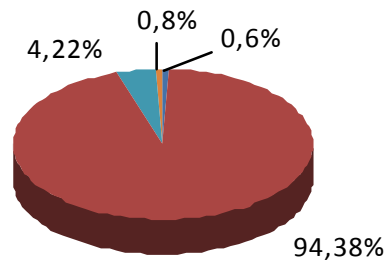

$50-60 \mathrm{~cm}$

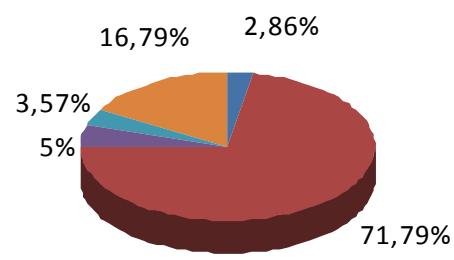

$70-80 \mathrm{~cm}$

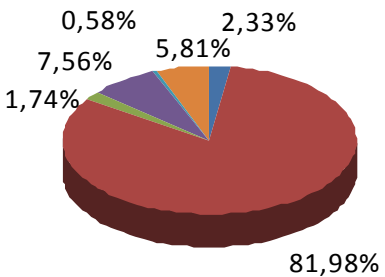

$90-100 \mathrm{~cm}$

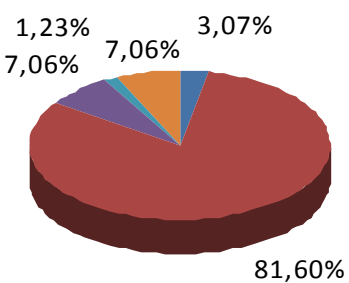

Cilindrico Cilindrico Achatado Esférico Esférico Achatado - Cúbico Disforme

Figura 28. Porcentagem de pellets para cada formato analisado por profundidade amostrada. 
$0-10 \mathrm{~cm}$

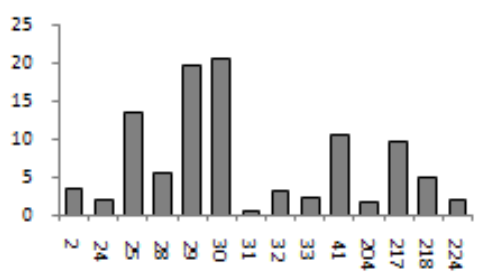

$20-30 \mathrm{~cm}$

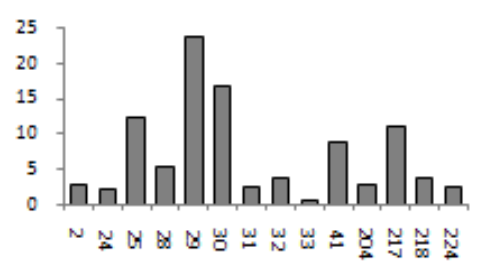

$40-50 \mathrm{~cm}$

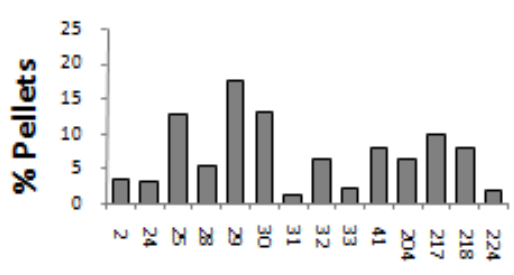

$60-70 \mathrm{~cm}$
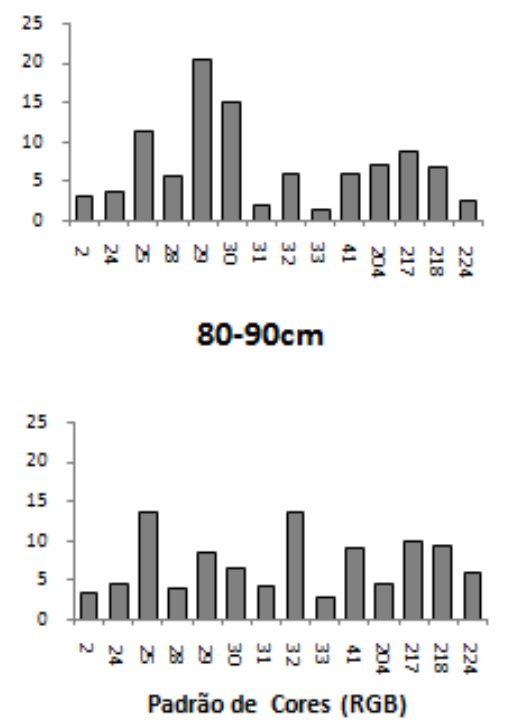

$10-20 \mathrm{~cm}$
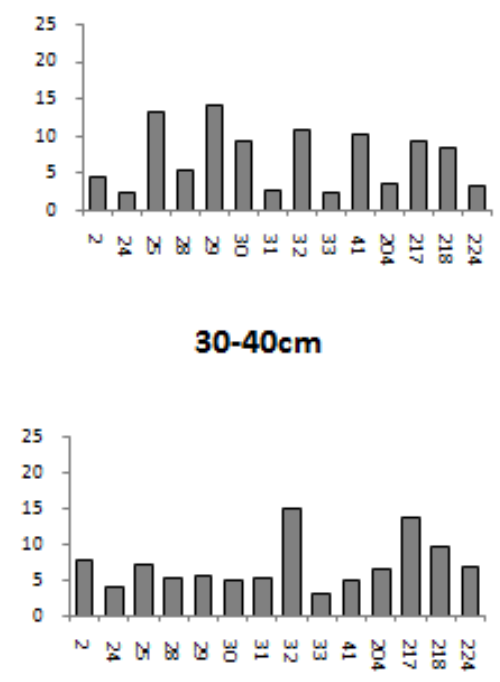

$50-60 \mathrm{~cm}$

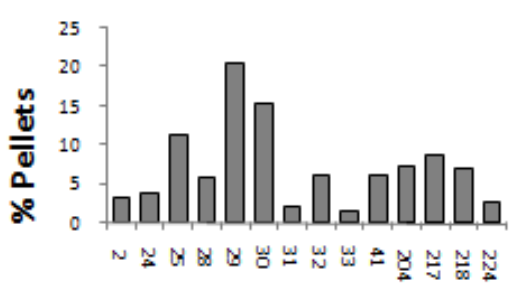

$70-80 \mathrm{~cm}$
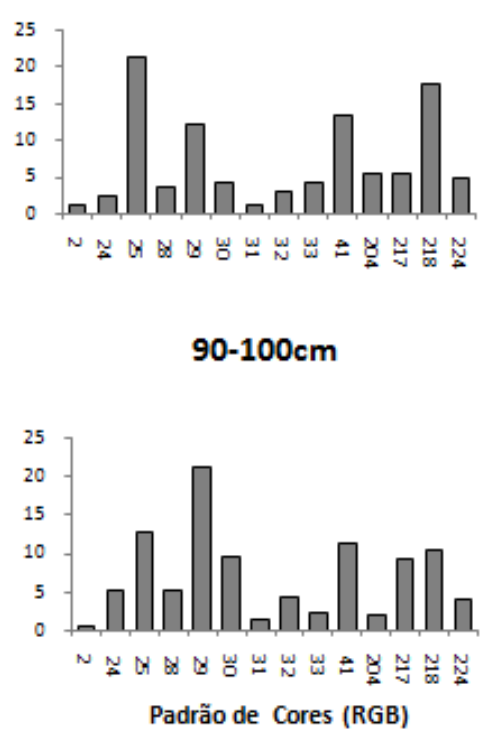

\begin{tabular}{|c|c|c|c|c|c|c|c|c|c|c|c|c|c|c|}
\hline Cor & & & & & & & & & & & & & & \\
\hline Código & 2 & 24 & 25 & 28 & 29 & 30 & 31 & 32 & 33 & 41 & 204 & 217 & 218 & 224 \\
\hline \multirow{3}{*}{ RGB } & $0-$ & $255-$ & $255-$ & $255-$ & $255-$ & $255-$ & $204-$ & $204-$ & $204-$ & $204-$ & $153-$ & $153-$ & $153-$ & $1502-$ \\
& $0-$ & $204-$ & $204-$ & $255-$ & $255-$ & $255-$ & $153-$ & $153-$ & $153-$ & $204-$ & $102-$ & $51-$ & $102-$ & $51-$ \\
& 0 & 51 & 102 & 102 & 153 & 204 & 0 & 51 & 102 & 153 & 0 & 0 & 51 & 0 \\
\hline
\end{tabular}

Figura 29. Porcentagem de pellets classificados por padrões de cores em RGB. 


\section{Incrustação}
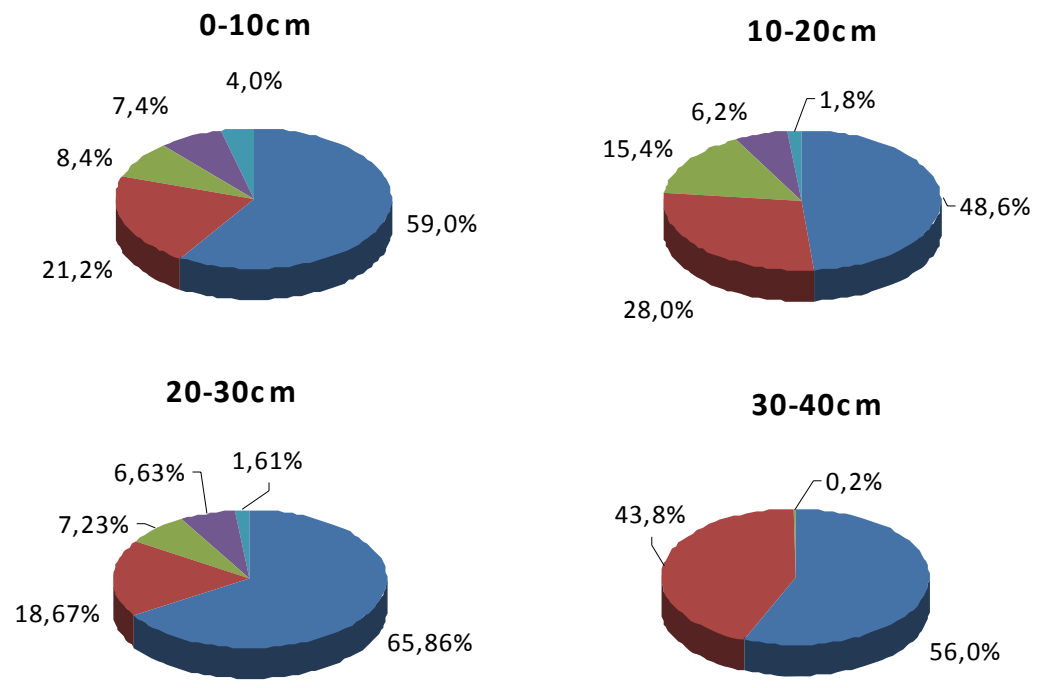

$30-40 \mathrm{~cm}$

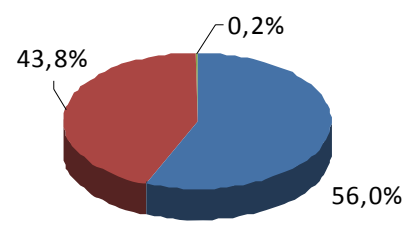

$40-50 \mathrm{~cm}$

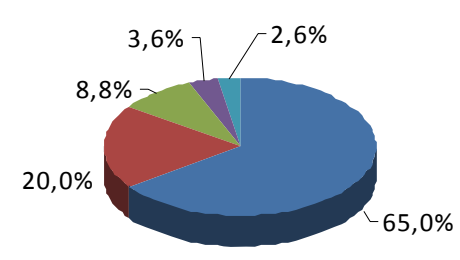

$60-70 \mathrm{~cm}$
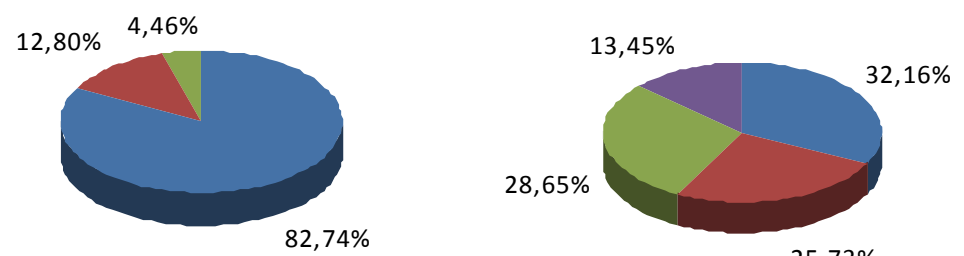

$25,73 \%$

$80-90 \mathrm{~cm}$

$90-100 \mathrm{~cm}$

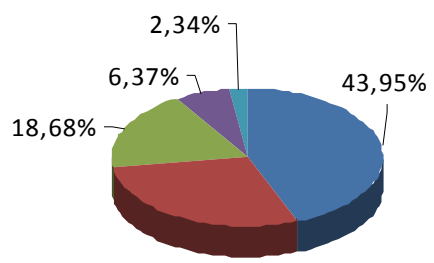

$28,66 \%$

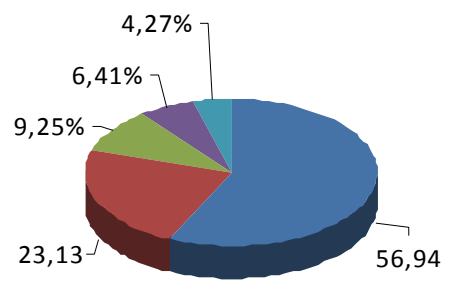

$70-80 \mathrm{~cm}$

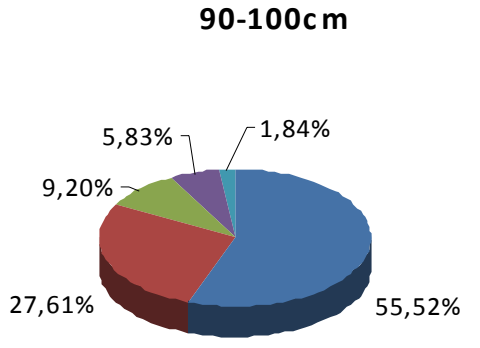
$0-20 \%$
$20-40 \%$
$40-60 \%$
$60-80 \%$
$80-100 \%$

Figura 30. Porcentagem de pellets em cada intervalo de $20 \%$ de incrustação por intervalo de profundidade. 


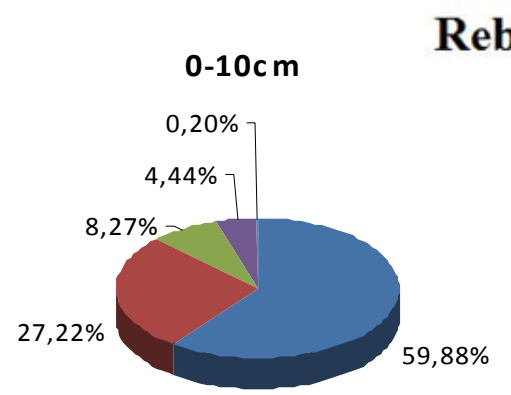

$20-30 \mathrm{~cm}$

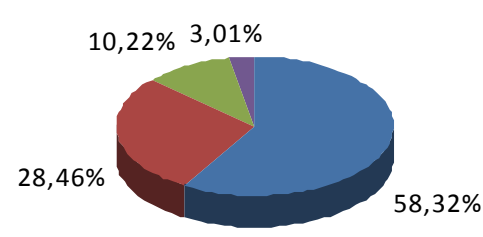

$40-50 \mathrm{~cm}$

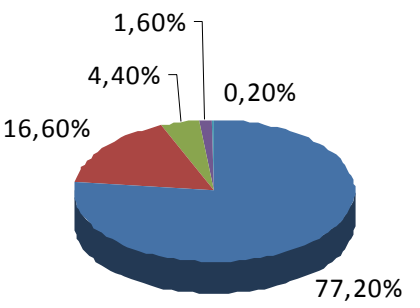

$60-70 \mathrm{~cm}$

$1,49 \%$

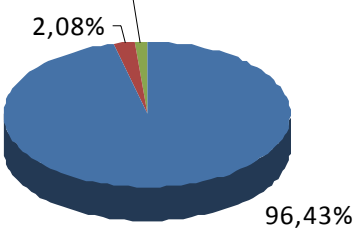

$80-90 \mathrm{~cm}$

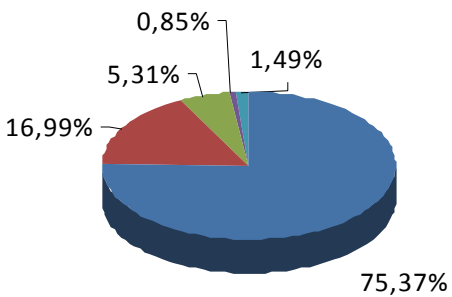

$0-20 \%$

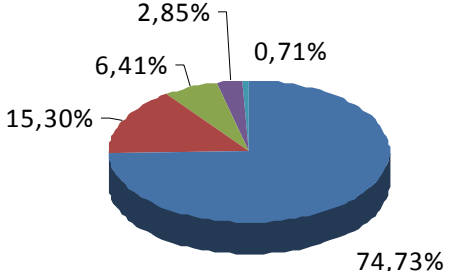

$70-80 \mathrm{~cm}$

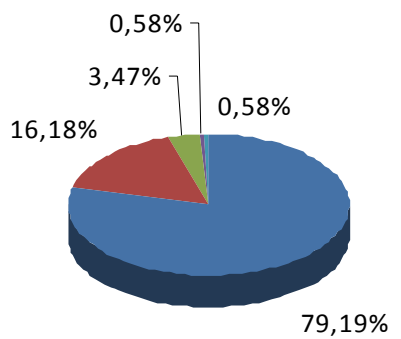

$90-100 \mathrm{~cm}$

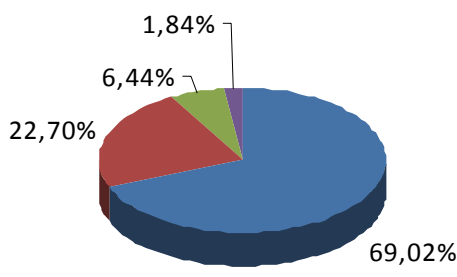

Figura 31. Porcentagem de pellets em cada intervalo de $20 \%$ de rebarba por intervalo de profundidade. 

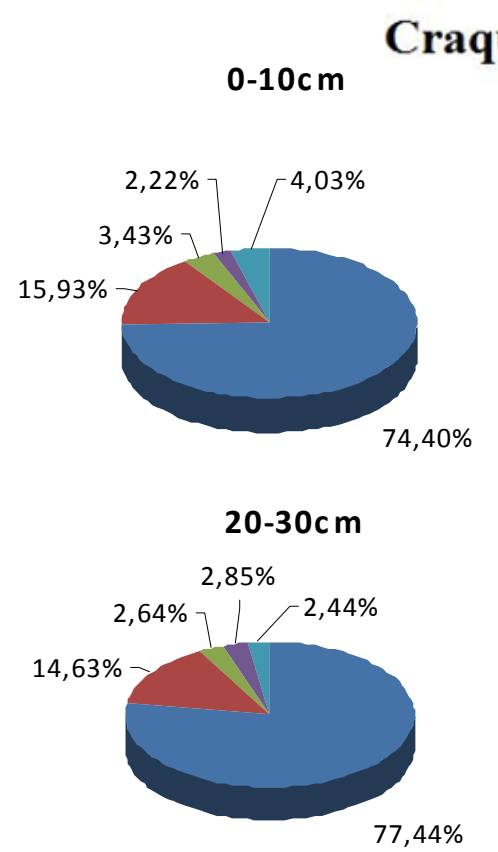

$40-50 \mathrm{~cm}$

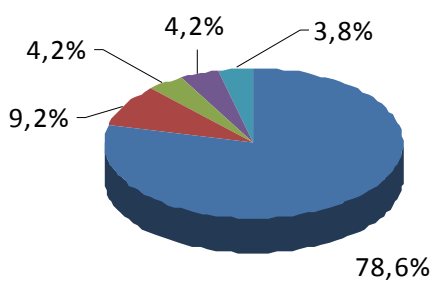

$60-70 \mathrm{~cm}$

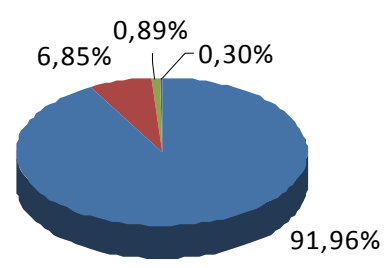

$80-90 \mathrm{~cm}$

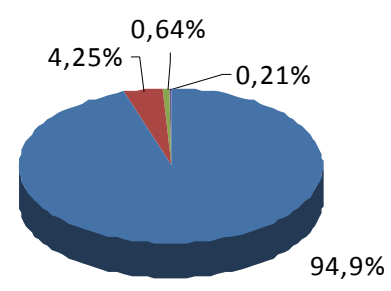

$0-20 \%$

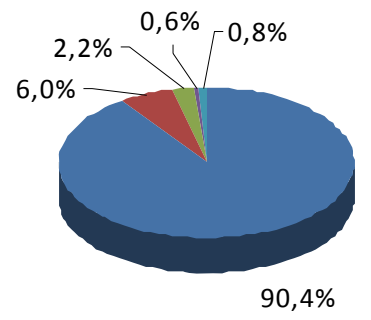

$30-40 \mathrm{~cm}$

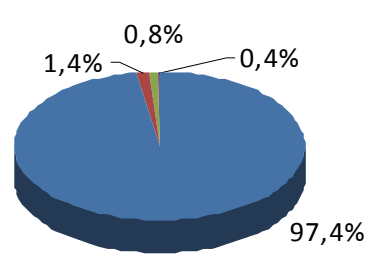

$50-60 \mathrm{~cm}$

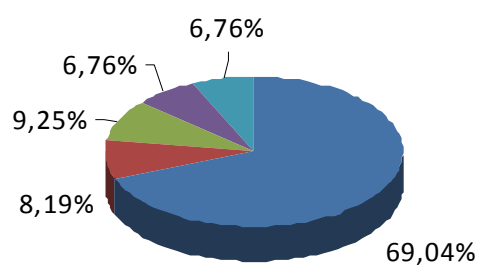

$70-80 \mathrm{~cm}$

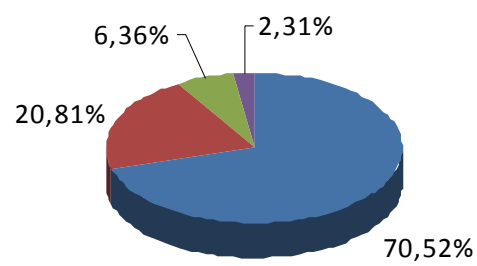

$90-100 \mathrm{~cm}$

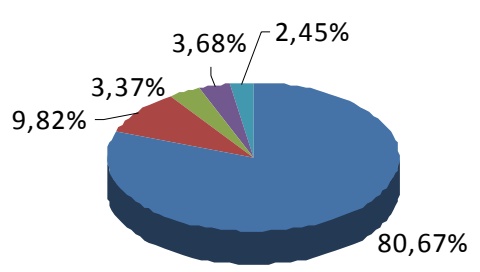

$60-80 \% \quad 80-100 \%$

Figura 32. Porcentagem de pellets em cada intervalo de $20 \%$ de craquelamento por intervalo de profundidade. 


\subsection{Caracterização morfológica em relação à área e período de coleta na}

\section{linha de deixa e estação do ano}

Observou-se valores de altura concentrando-se entre 2,6-2,9mm (Figura 33). No entanto, a variação encontrada foi influenciada significativamente pelas áreas e estações do ano (Tabela 5). De uma forma geral a altura dos pellets foi maior no Inverno e menor na Primavera, não variando entre o Verão e Outono, que apresentaram valores intermediários (Inv>Ver=Out>Prim). Quanto à área, os pellets maiores foram encontrados nas áreas 3 e $4(1=2<3=4>5=6)$.

Em relação ao diâmetro os valores concentraram-se entre 4,0-4,2mm (Figura 34), mas a ANOVA também apontou para a correlação significativa entre o tamanho e as áreas e estações do ano (Tabela 6). Os maiores pellets foram encontrados no Verão (Ver>Inv=Prim=Out), não apresentando variação entre as áreas de coleta (o teste SNK não foi significativo ainda que a ANOVA tenha sido).

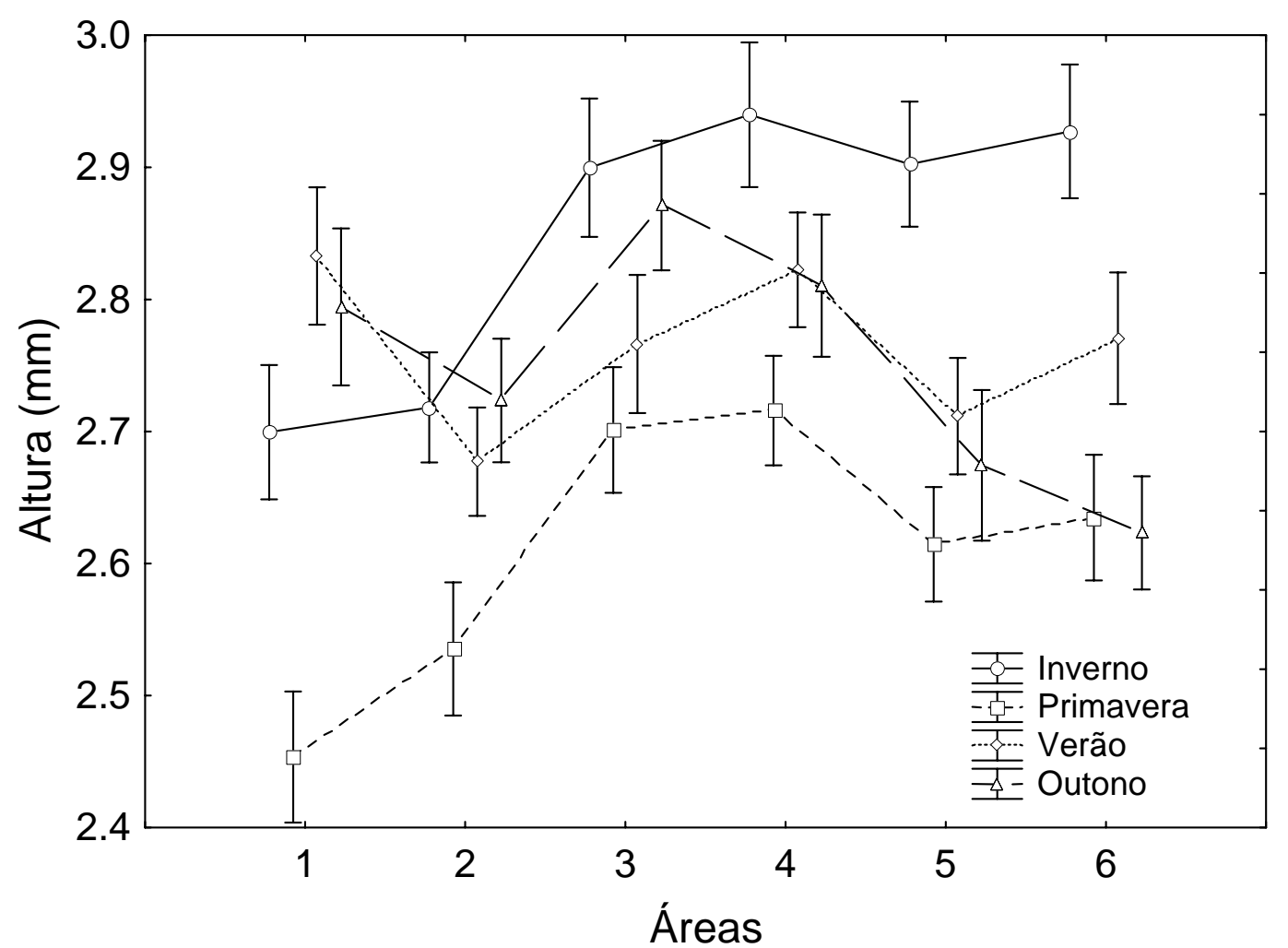

Figura 33. Média e erro padrão da altura dos pellets coletados na linha de deixa em diferentes áreas e estações do ano. 
Tabela 5. Análise de variância do tipo I de dois fatores para analisar a variação na altura dos pellets coletados na linha de deixa entre áreas de coleta e estações do ano.

\begin{tabular}{|c|c|c|c|c|}
\hline Efeito & GL & MS & F & p \\
\hline Intercepto & 1 & 43458.15 & 72501.41 & $<0.001$ \\
\hline Estação & 3 & 13.94 & 23.26 & $<0.001$ \\
\hline Área & 5 & 3.79 & 6.32 & $<0.001$ \\
\hline Estação*Área & 15 & 1.48 & 2.46 & 0.001 \\
\hline Erro & 5757 & 0.60 & & \\
\hline
\end{tabular}

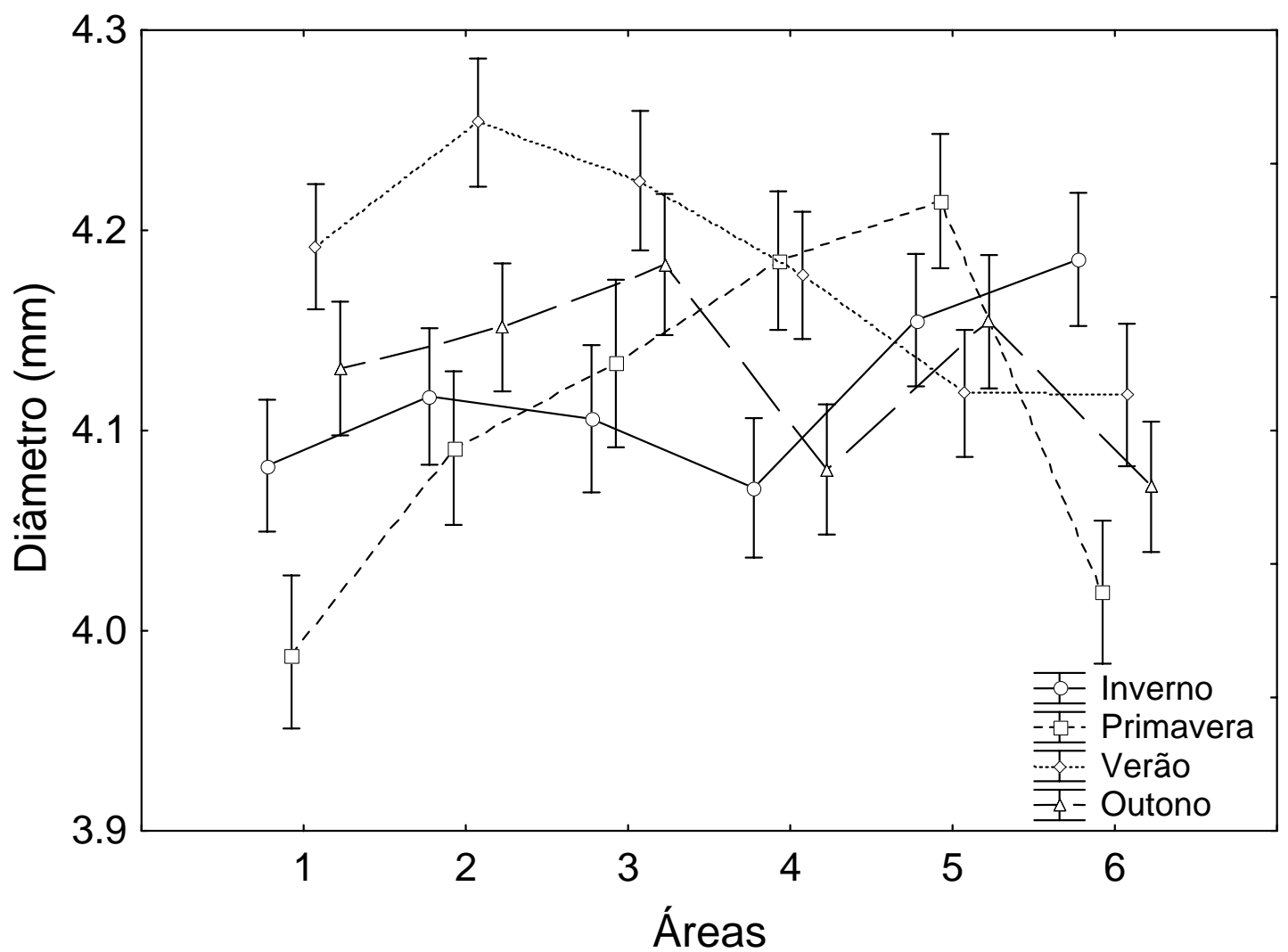

Figura 34. Média e erro padrão do diâmetro dos pellets coletados na linha de deixa em diferentes áreas e estações do ano. 
Tabela 6. Análise de variância do tipo I de dois fatores para analisar a variação no diâmetro dos pellets coletados na linha de deixa entre áreas de coleta e estações do ano.

\begin{tabular}{|c|c|c|c|c|}
\hline Efeito & GL & MS & F & p \\
\hline Intercepto & 1 & 97232.37 & 329312.80 & $<0.001$ \\
\hline Estação & 3 & 1.55 & 5.20 & 0.001 \\
\hline Área & 5 & 0.83 & 2.80 & 0.01 \\
\hline Estação*Área & 15 & 0.90 & 3.00 & $<0.001$ \\
\hline Erro & 5672 & 0.30 & & \\
\hline
\end{tabular}

A porcentagem de pellets nas diversas formas está apresentada na Tabela 7. Assim como na análise anterior, a maior porcentagem ocorreu na forma cilíndricoachatado, seguida por esférico-achatado. De uma forma geral, a forma dos pellets variou entre as áreas nas quatro estações analisadas, porém sem um padrão definido. A comparação dos valores totais (soma das áreas; Tabela 7) entre estações revelou que o formato dos pellets variou ao longo do ano $\left(\mathrm{X}^{2}=2122.17\right.$; $\left.\mathrm{GL}=21 ; \mathrm{p}=0.001\right)$.

A coloração dos pellets novamente manteve o padrão observado anteriormente (Tabela 8), com a maior parte apresentando tons em amarelo claro (cerca de 60 a 70\%) e o restante tons em marrom. Poucos apresentaram outras colorações. A coloração dos pellets também variou entre as áreas em relação às estações do ano, porém sem apresentar um padrão definido. A comparação dos valores totais (soma das áreas; Tabela 8) entre estações revelou que a coloração dos pellets também variou ao longo do ano $\left(\mathrm{X}^{2}=139.66 ; \mathrm{GL}=39 ; \mathrm{p}<0.001\right)$. 
Tabela 7. Porcentagem de pellets para cada formato analisado, de acordo com as áreas e as estações do ano (formas: Cilíndrico, Cilíndrico-achatado, Esférico, Esférico-achatado, Retangular, Cúbica e Disforme). Os valores de qui-quadrado referem-se às comparações entre áreas dentro de cada estação do ano.

\begin{tabular}{|c|c|c|c|c|c|c|c|}
\hline & Cilíndr. & Cilíndr. Ach. & Esfér. & Esf. Ach. & Retang. & Cúb. & Disforme \\
\hline \multicolumn{8}{|l|}{ Inverno } \\
\hline 1 & 8,0 & 54,0 & 1,2 & 30,4 & 1,2 & 1,2 & 4,0 \\
\hline 2 & 6,4 & 36,0 & 0,8 & 46,0 & 2,8 & 0,8 & 7,2 \\
\hline 3 & 11,6 & 44,4 & 2,8 & 32,0 & 1,2 & 3,6 & 4,4 \\
\hline 4 & 11,2 & 37,6 & 2,0 & 40,4 & 1,6 & 2,4 & 4,8 \\
\hline 5 & 9,2 & 47,2 & 1,6 & 36,0 & 0,0 & 1,6 & 4,4 \\
\hline 6 & 10,4 & 43,2 & 0,4 & 39,2 & 1,2 & 0,8 & 4,8 \\
\hline \multirow[t]{2}{*}{ Total } & 9,5 & 43,7 & 1,5 & 37,3 & 1,3 & 1,7 & 4,9 \\
\hline & \multicolumn{7}{|c|}{$X^{2}=54.68 ; G L=30 ; p=0.004$} \\
\hline \multicolumn{8}{|l|}{ Primavera } \\
\hline 1 & 3,6 & 33,2 & 1,6 & 48,4 & 2,0 & 0,8 & 10,4 \\
\hline 2 & 5,6 & 47,2 & 0,4 & 43,2 & 0,0 & 0,0 & 3,6 \\
\hline 3 & 9,2 & 54,0 & 0,0 & 30,0 & 0,4 & 1,2 & 5,2 \\
\hline 4 & 8,4 & 59,2 & 0,0 & 29,2 & 0,0 & 0,8 & 2,4 \\
\hline 5 & 6,0 & 63,6 & 0,0 & 25,6 & 1,2 & 0,0 & 3,6 \\
\hline 6 & 6,4 & 56,8 & 2,4 & 28,0 & 0,4 & 0,8 & 5,2 \\
\hline \multirow[t]{2}{*}{ Total } & 6,5 & 52,3 & 0,7 & 34,1 & 0,7 & 0,6 & 5,1 \\
\hline & \multicolumn{7}{|c|}{$X^{2}=122.25 ; G L=30 ; p<0.001$} \\
\hline \multicolumn{8}{|l|}{ Verão } \\
\hline 1 & 6,8 & 71,6 & 0,4 & 17,2 & 0,8 & 0,8 & 2,4 \\
\hline 2 & 3,6 & 65,6 & 2,0 & 25,6 & 0,0 & 0,4 & 2,8 \\
\hline 3 & 6,8 & 62,4 & 0,0 & 26,0 & 0,8 & 0,8 & 3,2 \\
\hline 4 & 4,8 & 70,4 & 2,0 & 20,0 & 0,4 & 1,2 & 1,2 \\
\hline 5 & 5,2 & 68,4 & 0,0 & 22,0 & 0,4 & 0,0 & 4,0 \\
\hline 6 & 10,0 & 59,2 & 0,4 & 26,0 & 0,0 & 0,8 & 3,6 \\
\hline \multirow[t]{2}{*}{ Total } & 6,2 & 66,3 & 0,8 & 22,8 & 0,4 & 0,7 & 2,9 \\
\hline & \multicolumn{7}{|c|}{$X^{2}=47.36 ; G L=30 ; p=0.023$} \\
\hline \multicolumn{8}{|l|}{ Outono } \\
\hline 1 & 8,8 & 60,8 & 0,0 & 26,0 & 0,0 & 0,8 & 3,6 \\
\hline 2 & 6,4 & 69,2 & 1,2 & 19,6 & 0,4 & 0,8 & 2,4 \\
\hline 3 & 12,4 & 62,4 & 0,0 & 23,6 & 0,0 & 0,8 & 0,8 \\
\hline 4 & 8,8 & 67,2 & 0,4 & 22,8 & 0,0 & 0,4 & 0,4 \\
\hline 5 & 9,6 & 55,2 & 0,4 & 32,8 & 0,0 & 0,4 & 1,6 \\
\hline 6 & 6,8 & 59,2 & 0,8 & 32,0 & 0,0 & 0,4 & 0,8 \\
\hline \multirow[t]{2}{*}{ Total } & 8,8 & 62,3 & 0,5 & 26,1 & 0,1 & 0,6 & 1,6 \\
\hline & \multicolumn{7}{|c|}{$X^{2}=48.67 ; G L=30 ; p=0.017$} \\
\hline
\end{tabular}


Tabela 8. Porcentagem de pellets classificados por padrões de cor em RGB nas 6 áreas de coleta para cada estação do ano. Algumas cores não estão representadas por apresentarem, de uma forma geral, os menores índices. Ver Figura 29 para legenda de cores.

\begin{tabular}{|c|c|c|c|c|c|c|c|c|c|c|c|c|c|c|}
\hline & 2 & 24 & 25 & 28 & 29 & 30 & 31 & 32 & 33 & 41 & 204 & 217 & 218 & 224 \\
\hline \multicolumn{15}{|l|}{ Inverno } \\
\hline 1 & 1,0 & 3,8 & 6,7 & 11,1 & 11,1 & 4,3 & 5,3 & 6,7 & 4,8 & 9,1 & 8,2 & 13,0 & 7,2 & 7,7 \\
\hline 2 & 2,3 & 1,7 & 5,7 & 13,2 & 14,4 & 12,6 & 4,0 & 4,0 & 4,6 & 16,7 & 2,9 & 8,0 & 6,3 & 3,4 \\
\hline 3 & 2,1 & 3,6 & 5,2 & 9,4 & 15,1 & 10,9 & 2,6 & 2,6 & 7,8 & 11,5 & 3,6 & 9,4 & 6,8 & 9,4 \\
\hline 4 & 1,1 & 2,8 & 4,5 & 11,3 & 13,0 & 17,5 & 6,2 & 5,6 & 3,4 & 11,9 & 1,7 & 11,9 & 6,2 & 2,8 \\
\hline 5 & 0,0 & 4,4 & 4,4 & 12,8 & 13,3 & 15,0 & 0,6 & 2,2 & 10,0 & 13,3 & 3,9 & 11,1 & 6,1 & 2,8 \\
\hline 6 & 1,5 & 3,1 & 8,8 & 10,3 & 7,7 & 15,5 & 3,1 & 3,1 & 7,2 & 9,8 & 5,1 & 9,8 & 9,3 & 5,7 \\
\hline \multirow[t]{2}{*}{ Total } & 1,5 & 3,3 & 5,9 & 11,3 & 12,3 & 12,4 & 3,6 & 4,1 & 6,3 & 11,9 & 4,3 & 10,6 & 7,0 & 5,4 \\
\hline & \multicolumn{14}{|c|}{$X^{2}=98.01 ; G L=65 ; p=0.005$} \\
\hline \multicolumn{15}{|c|}{ Primavera } \\
\hline 1 & 0,6 & 6,1 & 17,9 & 10,1 & 8,4 & 5,0 & 3,3 & 4,5 & 5,0 & 11,7 & 2,8 & 6,7 & 10,6 & 7,3 \\
\hline 2 & 0,5 & 5,9 & 14,6 & 9,7 & 13,5 & 9,2 & 4,3 & 4,3 & 5,9 & 13,5 & 2,7 & 8,1 & 4,3 & 3,2 \\
\hline 3 & 0,0 & 2,1 & 12,2 & 8,5 & 14,3 & 6,9 & 3,2 & 6,3 & 12,7 & 12,2 & 1,1 & 5,8 & 9,5 & 5,3 \\
\hline 4 & 1,0 & 3,4 & 4,4 & 14,6 & 16,0 & 8,7 & 5,8 & 7,8 & 1,5 & 14,1 & 4,4 & 8,2 & 7,8 & 2,4 \\
\hline 5 & 1,6 & 5,3 & 10,5 & 11,0 & 11,6 & 7,4 & 4,2 & 4,2 & 8,9 & 13,2 & 5,3 & 6,3 & 6,8 & 3,7 \\
\hline 6 & 2,0 & 6,7 & 7,8 & 8,8 & 8,8 & 4,1 & 4,7 & 3,6 & 9,3 & 11,4 & 7,8 & 7,2 & 10,4 & 7,2 \\
\hline \multirow[t]{2}{*}{ Total } & 1,0 & 4,9 & 11,0 & 10,5 & 12,2 & 6,9 & 4,3 & 5,2 & 7,2 & 12,7 & 4,0 & 7,1 & 8,2 & 4,8 \\
\hline & \multicolumn{14}{|c|}{$X^{2}=108.22 ; G L=65 ; p=0.001$} \\
\hline \multicolumn{15}{|l|}{ Verão } \\
\hline 1 & 0,0 & 3,6 & 3,1 & 7,3 & 8,3 & 9,9 & 9,4 & 6,2 & 6,8 & 9,4 & 10,4 & 9,9 & 11,46 & 4,2 \\
\hline 2 & 2,1 & 2,1 & 7,9 & 9,5 & 11,6 & 12,7 & 3,2 & 4,2 & 6,3 & 11,1 & 9,0 & 9,0 & 6,9 & 4,2 \\
\hline 3 & 1,6 & 4,2 & 3,1 & 9,9 & 8,8 & 12,5 & 4,2 & 4,2 & 10,4 & 12,0 & 7,8 & 11,5 & 5,7 & 4,2 \\
\hline 4 & 1,5 & 3,5 & 6,5 & 12,9 & 7,5 & 11,4 & 4,0 & 4,5 & 8,0 & 12,9 & 6,0 & 7,5 & 7,5 & 6,5 \\
\hline 5 & 1,6 & 3,2 & 9,2 & 7,6 & 9,7 & 9,7 & 2,2 & 7,6 & 4,3 & 14,0 & 6,5 & 7,6 & 6,5 & 10,3 \\
\hline 6 & 3,0 & 4,5 & 10,5 & 13,0 & 9,0 & 7,5 & 2,0 & 3,0 & 3,5 & 14,0 & 9,0 & 10,5 & 5,5 & 4,5 \\
\hline \multirow[t]{2}{*}{ Total } & 1,6 & 3,5 & 6,7 & 10,1 & 9,1 & 10,6 & 4,1 & 5,0 & 6,6 & 12,3 & 8,1 & 9,3 & 7,2 & 5,6 \\
\hline & \multicolumn{14}{|c|}{$X^{2}=89.67 ; G L=65 ; p=0.023$} \\
\hline \multicolumn{15}{|l|}{ Outono } \\
\hline 1 & 0,5 & 2,9 & 7,6 & 10,9 & 10,0 & 3,8 & 4,8 & 8,6 & 4,3 & 9,5 & 13,8 & 7,6 & 9,0 & 6,7 \\
\hline 2 & 1,9 & 3,3 & 6,2 & 6,7 & 6,2 & 11,5 & 2,9 & 9,6 & 5,3 & 8,6 & 8,6 & 7,7 & 13,9 & 7,7 \\
\hline 3 & 0,5 & 2,6 & 8,8 & 9,4 & 9,4 & 3,1 & 6,2 & 7,8 & 6,8 & 14,1 & 6,8 & 12,5 & 5,7 & 6,2 \\
\hline 4 & 0,5 & 4,9 & 9,8 & 5,8 & 11,2 & 3,4 & 2,9 & 4,4 & 5,8 & 16,1 & 8,3 & 8,8 & 7,3 & 10,7 \\
\hline 5 & 0,5 & 2,2 & 9,2 & 9,8 & 11,4 & 6,5 & 5,4 & 6,0 & 3,8 & 15,8 & 9,2 & 9,8 & 7,1 & 3,3 \\
\hline 6 & 1,4 & 2,4 & 6,2 & 10,5 & 12,4 & 8,6 & 3,8 & 5,7 & 6,2 & 11,5 & 4,8 & 12,4 & 7,2 & 6,7 \\
\hline \multirow[t]{2}{*}{ Total } & 0,9 & 3,0 & 7,9 & 8,85 & 10,1 & 6,2 & 4,3 & 7,0 & 5,4 & 12,5 & 8,6 & 9,8 & 8,4 & 7,0 \\
\hline & \multicolumn{14}{|c|}{$X^{2}=94.59 ; G L=65 ; p=0.001$} \\
\hline
\end{tabular}

A porcentagem de pellets com níveis de incrustações, rebarbas e craquelamento, em intervalos de 20\%, está apresentada na Tabela 9. Observou-se novamente uma maior quantidade de pellets com baixos graus de alterações, com mais 
da metade presente no intervalo entre $0-20 \%$. No entanto, de uma forma geral e em comparação com os dados anteriores, os pellets apresentaram índices de desgaste maiores. Uma parcela significativa apresentou índices de $80-100 \%$ de alteração na superfície, evidenciando que as partículas que estão sendo depositadas na linha de deixa estão mais alteradas (sofreram mais desgastes e/ou incrustação) do que aquelas que já estão soterradas há algum tempo.

Através do qui-quadrado foram analisados os dados do grau de preservação dos pellets relativo às 6 áreas amostrados a cada estação do ano (para testar a variação entre as áreas) e o total de pellets nas 6 áreas para todas as estações (para testar a variação entre as estações). Os resultados mostraram que, com exceção das estações Inverno, Primavera e Verão, para a característica rebarba, todas as outras relações mostraram-se significativas para o grau de preservação dos pellets em relação às áreas de coleta e às estações do ano (apresentadas na Tabela 9).

De uma forma geral, o índice de desgaste dos pellets variou entre as áreas nas quatro estações analisadas, porém sem um padrão definido. A comparação dos valores totais (soma das áreas; Tabela 9) entre estações revelou que os índices de desgaste dos pellets variou ao longo do ano (Incrustação: $X^{2}=84.38$; $G L=12 ; p<0.001$; Rebarba: $\mathrm{X}^{2}=85.04 ; \mathrm{GL}=12 ; \mathrm{p}<0.001$; Craquelamento: $\mathrm{X}^{2}=120.78 ; \mathrm{GL}=12 ; \mathrm{p}<0.001$ ). 
Tabela 9. Porcentagem de pellets em cada intervalo de $20 \%$ de Incrustação, Rebarba e Craquelamento nas 6 áreas de coleta em cada estação do ano.

\begin{tabular}{|c|c|c|c|c|c|c|c|c|c|c|c|c|c|c|c|}
\hline & \multicolumn{5}{|c|}{ Incrustação (\%) } & \multicolumn{5}{|c|}{ Rebarba (\%) } & \multicolumn{5}{|c|}{ Craquelamento (\%) } \\
\hline & $\begin{array}{l}0- \\
20\end{array}$ & $\begin{array}{c}20- \\
40\end{array}$ & $\begin{array}{c}40- \\
60\end{array}$ & $\begin{array}{c}60- \\
80\end{array}$ & $\begin{array}{l}80- \\
100\end{array}$ & $\begin{array}{l}0- \\
20\end{array}$ & $\begin{array}{c}20- \\
40\end{array}$ & $\begin{array}{l}40- \\
60\end{array}$ & $\begin{array}{c}60- \\
80\end{array}$ & $\begin{array}{l}80- \\
100\end{array}$ & $\begin{array}{l}0- \\
20\end{array}$ & $\begin{array}{c}20- \\
40\end{array}$ & $\begin{array}{c}40- \\
60\end{array}$ & $\begin{array}{c}60- \\
80\end{array}$ & $\begin{array}{l}80- \\
100\end{array}$ \\
\hline \multicolumn{16}{|l|}{ Inverno } \\
\hline 1 & 53,2 & 16,0 & 2,0 & 3,6 & 25,2 & 75,2 & 10,4 & 2,0 & 2,8 & 9,6 & 76,8 & 9,6 & 2,4 & 2,4 & 8,8 \\
\hline 2 & 60,4 & 5,6 & 4,0 & 7,2 & 22,8 & 81,6 & 4,4 & 2,4 & 1,6 & 10,0 & 72,4 & 6,0 & 3,2 & 5,2 & 13,2 \\
\hline 3 & 60,0 & 8,4 & 2,8 & 4,4 & 24,4 & 74,0 & 7,6 & 3,6 & 4,8 & 10,0 & 84,8 & 3,6 & 1,6 & 2,8 & 7,2 \\
\hline 4 & 56,8 & 4,0 & 4,0 & 4,0 & 31,2 & 86,0 & 4,0 & 2,0 & 2,4 & 5,6 & 82,8 & 6,8 & 3,6 & 4,0 & 2,8 \\
\hline 5 & 54,8 & 9,2 & 3,2 & 3,6 & 29,2 & 77,2 & 8,0 & 2,4 & 3,6 & 8,8 & 90,4 & 3,6 & 2,0 & 2,0 & 2,0 \\
\hline 6 & 55,6 & 8,8 & 2,8 & 8,0 & 24,8 & 82,8 & 4,8 & 3,2 & 2,4 & 6,8 & 74,0 & 6,0 & 4,4 & 6,8 & 8,8 \\
\hline \multirow[t]{2}{*}{ Total } & 56,8 & 8,7 & 3,1 & 5,1 & 26,3 & 79,5 & 6,5 & 2,6 & 2,9 & 8,5 & 80,2 & 5,9 & 2,9 & 3,9 & 7,1 \\
\hline & \multicolumn{5}{|c|}{$X^{2}=43.03 ; G L=20 ; p=0.002$} & \multicolumn{5}{|c|}{$X^{2}=28.32 ; G L=20 ; p=0.102$} & \multicolumn{5}{|c|}{$X^{2}=64.77 ; G L=20 ; p<0.001$} \\
\hline
\end{tabular}

\section{Primavera}

\begin{tabular}{|c|c|c|c|c|c|c|c|c|c|c|c|c|c|c|c|}
\hline 1 & 47,6 & 5,6 & 4,0 & 6,8 & 36 & 86 & 3,6 & 2,0 & 0,8 & 7,6 & 74,4 & 2,4 & 4,0 & 4,8 & 14,4 \\
\hline 2 & 51,2 & 8,4 & 3,6 & 6,4 & 30,4 & 90,4 & 2,4 & 1,6 & 2,4 & 3,2 & 70,8 & 7,6 & 4,0 & 7,6 & 10,0 \\
\hline 3 & 44,8 & 8,0 & 5,2 & 9,2 & 32,8 & 91,2 & 3,2 & 0,8 & 0,8 & 4,0 & 78 & 6,0 & 2,4 & 7,2 & 6,4 \\
\hline 4 & 58,4 & 12,4 & 6,4 & 6,4 & 16,4 & 89,6 & 3,2 & 0,4 & 2,4 & 4,4 & 69,6 & 10,4 & 5,6 & 8,4 & 6,0 \\
\hline 5 & 57,2 & 8,4 & 3,6 & 5,2 & 25,6 & 85,6 & 5,2 & 3,2 & 1,2 & 4,8 & 77,6 & 7,2 & 2,8 & 2,0 & 10,4 \\
\hline 6 & 46,8 & 10,8 & 7,6 & 6,0 & 28,8 & 90,8 & 2,8 & 1,2 & 1,2 & 4,0 & 70,4 & 6,4 & 5,6 & 4,8 & 12,8 \\
\hline \multirow[t]{2}{*}{ Total } & 51,0 & 8,9 & 5,0 & 6,7 & 28,3 & 88,9 & 3,4 & 1,5 & 1,5 & 4,7 & 73,5 & 6,7 & 4,1 & 5,8 & 10,0 \\
\hline & \multicolumn{5}{|c|}{$X^{2}=46.48 ; G L=20 ; p=0.001$} & \multicolumn{5}{|c|}{$X^{2}=23.40 ; G L=20 ; p=0.270$} & \multicolumn{5}{|c|}{$X^{2}=46.97 ; G L=20 ; p=0.006$} \\
\hline \multicolumn{16}{|l|}{ Verão } \\
\hline 1 & 58,4 & 12,4 & 2,8 & 2,4 & 24,0 & 86,4 & 7,2 & 1,2 & 2,0 & 3,2 & 70,4 & 8,4 & 4,4 & 4,0 & 12,8 \\
\hline 2 & 71,6 & 4,4 & 1,6 & 0,8 & 21,6 & 87,2 & 4,4 & 0,8 & 0,4 & 7,2 & 63,6 & 17,6 & 2,4 & 5,6 & 10,8 \\
\hline 3 & 60,0 & 9,6 & 1,6 & 1,6 & 27,2 & 83,2 & 4,8 & 4,8 & 1,6 & 5,6 & 72,0 & 14,0 & 2,4 & 3,6 & 8,0 \\
\hline 4 & 58,4 & 9,2 & 2,8 & 4,0 & 25,6 & 84,0 & 6,8 & 1,2 & 1,2 & 6,8 & 77,2 & 10,0 & 1,2 & 3,6 & 8,0 \\
\hline 5 & 62,8 & 6,8 & 2,4 & 2,0 & 26,0 & 85,2 & 4,0 & 1,2 & 2,8 & 6,8 & 62,4 & 14,8 & 2,8 & 4,4 & 15,6 \\
\hline 6 & 60,8 & 11,2 & 4,4 & 5,2 & 18,4 & 86,8 & 5,6 & 2 & 1,6 & 4,0 & 62,4 & 12,8 & 3,6 & 5,2 & 16 \\
\hline \multirow[t]{2}{*}{ Total } & 62,0 & 8,9 & 2,6 & 2,7 & 23,8 & 85,5 & 5,5 & 1,9 & 1,6 & 5,6 & 68,0 & 12,9 & 2,8 & 4,4 & 11,9 \\
\hline & \multicolumn{5}{|c|}{$X^{2}=40.27 ; G L=20 ; p=0.005$} & \multicolumn{5}{|c|}{$X^{2}=30.28 ; G L=20 ; p=0.065$} & \multicolumn{5}{|c|}{$X^{2}=38.360 ; G L=20 ; p=0.008$} \\
\hline \multicolumn{16}{|l|}{ Outono } \\
\hline 1 & 50,4 & 12,4 & 2,0 & 4,4 & 30,8 & 82,0 & 4,8 & 2,8 & 2,0 & 8,4 & 73,2 & 9,2 & 1,6 & 4,0 & 12,0 \\
\hline 2 & 45,2 & 16,0 & 3,2 & 5,2 & 30,4 & 80,4 & 5,2 & 2,0 & 3,6 & 8,8 & 82,4 & 3,6 & 0,4 & 3,2 & 10,4 \\
\hline 3 & 50,0 & 11,6 & 4,4 & 8,0 & 26,0 & 73,2 & 6,4 & 2,8 & 2,0 & 15,6 & 76,4 & 3,6 & 1,2 & 3,6 & 15,2 \\
\hline 4 & 52,4 & 14,8 & 4,8 & 4,8 & 23,2 & 81,2 & 7,2 & 2,0 & 1,6 & 8,0 & 76,0 & 8,0 & 1,6 & 4,4 & 10,0 \\
\hline 5 & 58,8 & 8,4 & 5,2 & 4,4 & 23,2 & 79,2 & 6,8 & 1,2 & 2,0 & 10,8 & 80,0 & 4,8 & 1,6 & 4,0 & 9,6 \\
\hline 6 & 59,6 & 14,8 & 2,0 & 2,4 & 21,2 & 78,0 & 12,8 & 0,0 & 2,4 & 6,8 & 72,8 & 10,8 & 4,4 & 1,2 & 10,8 \\
\hline \multirow[t]{2}{*}{ Total } & 52,7 & 13,0 & 3,6 & 4,9 & 25,8 & 79,0 & 7,2 & 1,8 & 2,3 & 9,7 & 76,8 & 6,7 & 1,8 & 3,4 & 11,3 \\
\hline & \multicolumn{5}{|c|}{$X^{2}=37.96 ; G L=20 ; p=0.009$} & \multicolumn{5}{|c|}{$\mathrm{X}^{2}=39.54 ; \mathrm{GL}=20 ; \mathrm{p}=0.006$} & \multicolumn{5}{|c|}{$X^{2}=42.53 ; G L=20 ; p=0.002$} \\
\hline
\end{tabular}




\section{Identificar as possíveis fontes de emissão de grânulos para a Enseada de}

\section{Santos.}

Para a identificação das fontes de emissão de pellets foi realizado um levantamento das empresas que produzem, transportam e utilizam este material nas proximidades da região, assim como simulações para avaliar a dispersão e deposição nas praias da Enseada de Santos. Os dados serão aqui apresentados pela seqüência dos setores envolvidos com os pellets levantados pela EPA (1992a): indústrias produtoras, transportadoras e processadoras. Ao final, informações a respeito das possíveis fontes serão apresentadas.

Atualmente, o número de unidades industriais produtoras de pellets $\left(2^{\mathrm{a}}\right.$ geração) é estimado em 50 para todo o país ${ }^{8}$. Das 11 grandes indústrias produtoras instaladas no Brasil 6 têm unidades representadas no Estado de São Paulo, e ainda 4 destas apresentam instalações na Baixada Santista tanto para a produção quanto para o transporte de produtos (marítimo e/ou terrestre, para importação e exportação). A maior concentração dessas instalações em Santos encontra-se próximo ao Porto de Santos, no Distrito Industrial e Portuário, denominado Alemôa. Neste local destaca-se o Terminal Soda Cloro da Braskem, indústria produtora de polímeros de Polietileno no município de Triunfo (RS), PVC em São Paulo (SP) e Polipropileno em Paulínia (interior de SP), esta última com uma produção de PP estimada em 350 mil toneladas/ano 9 .

Em Alemôa destaca-se também a Pepasa, indústria fundada em 1969 produtora de polímeros termoplásticos de Nylon, Polipropileno, PEAD, ABS e Policarbonato, reforçados com fibra de vidro ou com cargas minerais. Como esta indústria não está vinculada a nenhuma outra empresa, desenvolve e produz compostos baseados em toda e qualquer resina termoplástica. Isso lhe permite selecionar livremente as resinas e, com o uso de reforços, cargas e aditivos, formular um número crescente de produtos abrangendo extensa faixa de propriedades físicas. Além da blendagem de resinas com reforços e cargas, a Pepasa passou também a associar resinas, compatibilizando-as e

\footnotetext{
${ }^{8}$ www.suzanopetroquimica.com.br

${ }^{9}$ www.braskem.com.br
} 
gerando novos materiais, como blendas e ligas de ABS/PC, ABS/PU, PA/PP, PA/PE, $\mathrm{POM} / \mathrm{PU}, \mathrm{PC} / \mathrm{PBT}, \mathrm{PC} /$ Acrílico, entre outras ${ }^{10}$.

A unidade da Dow Química na região faz parte do município do Guarujá, mas também está situada nos entornos do Canal de Santos, juntamente com seu terminal de cargas (entre o porto e a boca do canal). Este complexo industrial iniciou suas atividades na região em 1971 e é formado por cinco fábricas que produzem pellets de Epóxi, Polióis, Poliglicóis, Látex e Poliestireno. O Terminal Marítimo é o segundo mais movimentado da Dow, estocando e distribuindo produtos e matérias-primas das fábricas do Guarujá/SP e Aratu/BA. Dispõe de 29 tanques de armazenamento de matéria-prima e recebe anualmente 20 mil caminhões e 115 navios. Por ele passam 70\% das vendas da Dow na América Latina. Os produtos fabricados no Guarujá respondem por 70\% da distribuição de produtos no Brasil, devido à privilegiada posição geográfica estratégica deste Complexo Industrial. Em 2006, cerca de 275 ton foram produzidas ${ }^{11}$.

No município de Cubatão foi instalada na década de 70 uma unidade da Polietilenos União, indústria que produz, juntamente com a unidade de Capuava (localizada em Santo André, interior do estado de SP) cerca de 500 mil toneladas/ano de polímeros de Polietileno de Baixa Densidade (PEBD) ${ }^{12}$.

A partir da visita realizada à unidade da Braskem os processos que envolvem a produção dos pellets foram identificados, mas não foram observados possíveis fontes de perda para o ambiente.

Não foi possível o levantamento das indústrias transportadoras devido à dificuldades no acesso a esse tipo de dado. No entanto, contatos por telefone com setores específicos do Porto de Santos relacionados ao meio ambiente e ao gerenciamento operacional foram realizados. As informações assim obtidas foram que os pellets antigamente eram empacotados em caixas de papelão ou em sacos plásticos menos resistentes, e atualmente são ensacados em bags e estes colocados dentro de containeres. O transporte dos pellets na região provavelmente é efetuado por caminhões, que circulam entre a área portuária e as rodovias ao redor, ligando principalmente a Baixada Santista à região do ABC Paulista (Grande São Paulo), cujas cidades

\footnotetext{
${ }^{10}$ www.pepasa.com.br

${ }^{11}$ www.dow.com

${ }^{12}$ www.polietilenos.com.br
} 
concentram um grande número de indústrias produtoras e transformadoras de pellets. Além disso, o transporte por navios também é significativo, já que na zona portuária há uma grande movimentação desse tipo de produto.

Como não foram detectadas indústrias transformadoras nesta região, uma possível fonte de pellets por sistema de drenagem é descartada. No Brasil, segundo a ABIQUIM (até 2007), a estimativa do número de indústrias transformadoras é de 11.329, e o estado de São Paulo concentra 44,6\% delas $(5.061)^{13}$.

Depoimentos de moradores também foram obtidos, apontando para a possibilidade de uso dos pellets para lavagem de porões das embarcações e posterior descarte irregular ao ambiente marinho, informação que não pôde ser comprovada até o momento.

Como já salientado, Harari e Gordon (2001) desenvolveram uma modelagem numérica para avaliar o grau de dispersão de substâncias e/ou partículas no Estuário de Santos. Essa modelagem foi adaptada para simular a dispersão dos pellets ao longo de 12 meses (referentes ao ano de 2008), a partir de 6 pontos escolhidos como prováveis fontes de emissão deste material para a região em questão. As posições das partículas no $1^{\circ}, 8^{\circ}$ e $12^{\circ}$ mês estão apresentadas nas figuras a seguir. Os resultados observados nos mapas mostram que a maioria dos pellets emitidos nas regiões internas do estuário não alcança a enseada em condições meteorológicas estáveis e/ou em um curto espaço de tempo (Figura 35). A maior parte dos que são lançados próximo à boca do estuário chegam rapidamente às praias (Figura 36) e uma grande parcela dos pellets emitidos ao largo da enseada é exportada para outras áreas, mas alguns ainda alcançam a porção interna desta região e podem se depositar nas praias (Figura 37).

${ }^{13}$ www.abiplast.org.br 

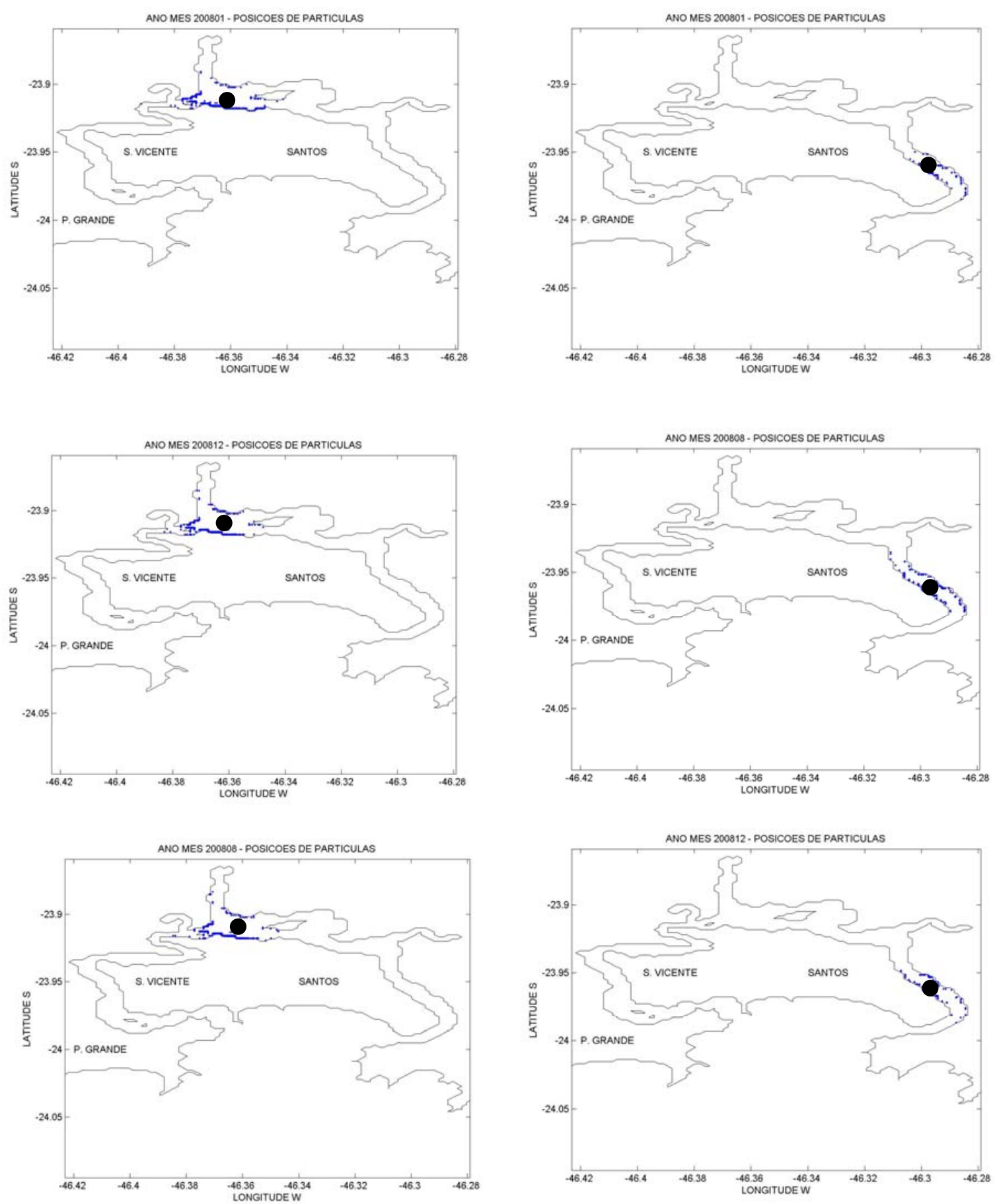

Figura 35. Dispersão dos pellets no $1^{\circ}, 8^{\circ}$ e $12^{\circ}$ mês relativos aos pontos 1 e 2 (respectivamente à coluna esquerda e direita) como possíveis fontes de emissão. 

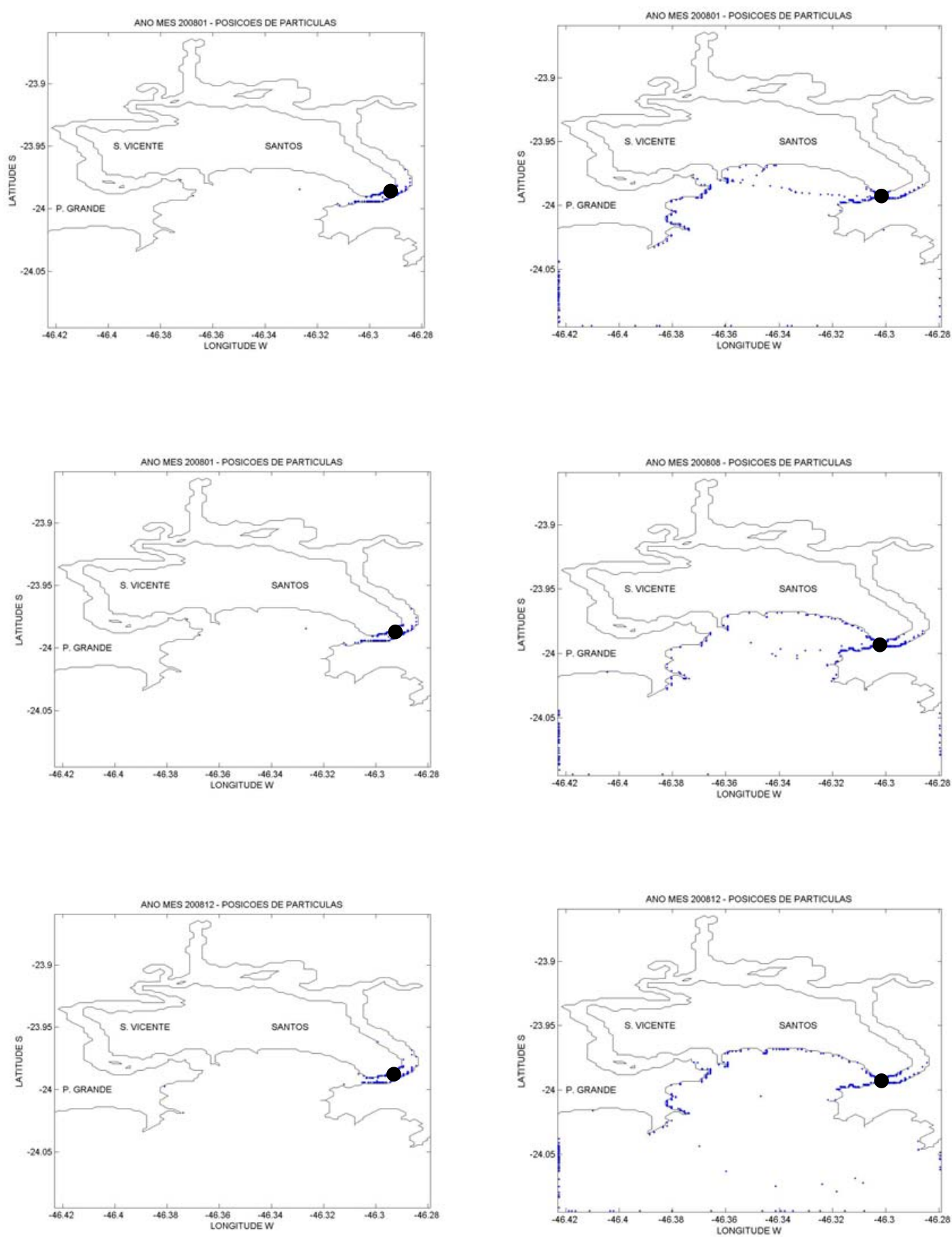

Figura 36. Dispersão dos pellets no $1^{\circ}, 8^{\circ}$ e $12^{\circ}$ mês relativos aos pontos 3 e 4 (respectivamente à coluna esquerda e direita) como possíveis fontes de emissão. 

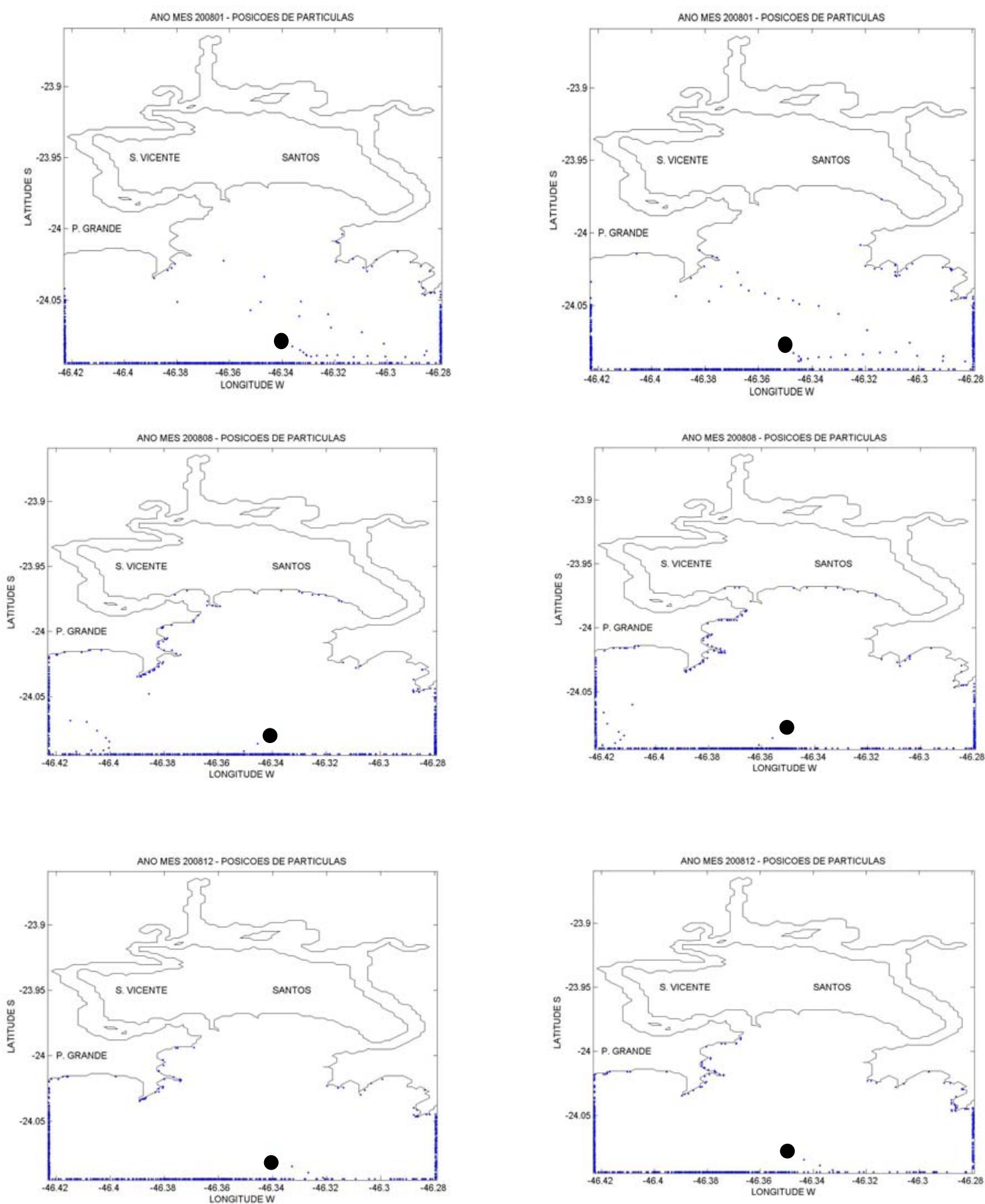

Figura 37. Dispersão dos pellets no $1^{\circ}, 8^{\circ}$ e $12^{\circ}$ mês relativos aos pontos 5 e 6 (respectivamente à coluna esquerda e direita) como possíveis fontes de emissão. 


\section{DISCUSSÃO}

\section{Compreender o padrão de distribuição dos grânulos plásticos nas praias da Enseada de Santos}

\subsection{Avaliar a distribuição dos grânulos em profundidade no sedimento}

Os resultados mostraram a maior abundância de pellets nas porções mais superiores do sedimento, já que em geral eles apresentam uma densidade menor que a água do mar (EPA, 1992a) e, por isso, têm uma tendência a não serem soterrados. Os resultados revelaram que os pellets devem estar sendo depositados há muito tempo e que a ocorrência em profundidade no sedimento pode ser decorrente de eventos extremos que remobilizaram e depois re-depositaram o sedimento com certa velocidade, aprisionando os pellets. Só eventos dessa magnitude teriam condições de soterrar esses pellets, pois possuem densidades baixas e bóiam na água o mar. Além disso, processos antrópicos também podem estar envolvidos, através do revolvimento de areia por tratores em porções mais superiores do sedimento, fato que está previsto para ser testado futuramente.

O método utilizado neste estudo foi semelhante a encontrada em outros (Kusui e Noda, 2003; McDermid e McMullen, 2004), diferindo principalmente em relação a profundidade amostrada. A maioria dos estudos quantitativos de resíduos sólidos em praias tendem a levar em consideração aqueles encontrados na superfície da areia (Gregory, 1977; Wilber, 1987; Pianowski, 1997; Karapanagioti e Klontza, 2007). Alguns, entretanto, consideraram a profundidade, mas apenas até $5.5 \mathrm{~cm}$ (Kusui e Noda, 2003; McDermid e McMullen, 2004). Nenhum trabalho até o momento levou em consideração os pellets encontrados a grandes profundidades no sedimento. A quantidade de resíduos enterrados é de significativa importância para que se possa estimar com segurança a quantidade total numa determinada praia. Kusui e Noda (2003) observaram que a quantidade de partículas encontradas enterradas a $5 \mathrm{~cm}$ na areia pode ser até 10 vezes maior em comparação com as encontradas na superfície. Nesse estudo foi estimada uma densidade de 0.52 pellets $/ \mathrm{m}^{2}$ na superfície $\left(8.878 \mathrm{~m}^{2}\right.$ de área amostrada; $\mathrm{n}=4623)$ e 1.230 pellets $/ \mathrm{m}^{3}$ enterrados (56 amostras de $40 \times 40 \times 5 \mathrm{~cm}=0.448 \mathrm{~m}^{3} ; \mathrm{n}=551$ ). 
Tais resultados evidenciam que na maioria dos estudos a quantidade real de pellets em praias pode estar sendo subestimada. Utilizando os dados obtidos neste pesquisa, a estimativa média de densidade de pellets nos $30 \mathrm{~cm}$ superiores no sedimento é de $11.000 / \mathrm{m}^{3}$. Comparando com outros trabalhos, as estimativas reais de densidade até esta profundidade em praias deveriam ser de 7.380/m³ em Kusui e Noda (2003), de 26.291/ $\mathrm{m}^{3}$ em McDermid e McMullen (2004), 3.369/m² em Pianowski (1997), cerca de 1.200.000/m² em Gregory (1977) e uma densidade máxima de 3.000.000 em Gregory (1978).

O período em que os pellets estão sendo depositados nas praias é difícil de ser estimado devido à impossibilidade em datar os pellets e ainda pois os resultados apontaram para um aumento no número de pellets nos intervalos de $30-40 \mathrm{~cm}$ e $60-70 \mathrm{~cm}$ de profundidade, evidenciando que a deposição provavelmente não ocorreu a taxas regulares ao longo do tempo.

\section{vertical) \\ 1.2. Avaliar a distribuição dos grânulos ao largo da praia (distribuição}

A concentração de pellets foi maior nas faixas mais superiores da praia devido provavelmente ao processo de espraiamento durante eventos de tempestades ocorridos ao longo dos anos na área. Esse processo está relacionado com movimentação ascendente da água da onda incidente após a arrebentação, através da face da praia. Esta movimentação de água transporta sedimentos para a parte superior da praia de acordo com a densidade das partículas. Verifica-se a seguir um refluxo, em que a água, devido à gravidade, se movimenta no sentido contrário, em direção ao oceano, e está relacionado com a remobilização dessas partículas. A resultante dos processos de espraiamento e refluxo das ondas tende a concentrar partículas menores na parte superior da face da praia e partículas maiores na parte inferior. Como os pellets, apesar de terem diâmetro maior que os grãos de areia, são menos densos que estes e do que a água do mar, depositam-se preferencialmente nas faixas mais superiores da zona de espraiamento. Com novos eventos de tempestade, esses pellets tendem a subir cada vez mais, explicando a maior concentração obtida nessas faixas.

Assim como neste estudo, outros também observaram esse padrão de distribuição ao largo de praias. Karapanagioti e Klontza (2007), por exemplo, observaram que mais de $95 \%$ dos pellets encontrados acumularam-se nas áreas 
superiores das 5 praias analisadas no estudo (menos de 5\% estava na área entremarés). Wilber (1987) também encontrou a maior parcela dos pellets na região mais alta da praia, depositada através de marés bem altas e/ou por eventos de tempestade, assim como Pianowski (1997) que menciona observações de um grande acúmulo de pellets na região das dunas de praias do RS. Em outro estudo, no entanto, a maior porção dos pellets foi encontrada na linha de deixa: McDermid e McMullen (2004) coletaram pequenos resíduos plásticos em 9 praias do Havaí, tanto na linha de maré alta $(n=13)$ quanto na berma ( $\mathrm{n}=9)$, através de 22 amostras de $61 \times 61 \times 5.5 \mathrm{~cm}\left(0.45 \mathrm{~m}^{3}\right) .0$ total de pellets coletado foi de 2.169 (11\% do material; 4.820pellets $\left./ \mathrm{m}^{3}\right)$; mais de $90 \%$ foi encontrado na linha de deixa, e o restante na zona de berma. Esse resultado foi explicado pelo fato dos pellets suspensos na água serem depositados na linha de deixa a cada retrocesso da maré, enquanto na área de berma eles seriam depositados apenas em eventos de tempestade ou por ventos fortes que sopram do mar, levando o material da linha da maré para as áreas mais altas da praia. Tal explicação sugere que a deposição dos pellets nestas praias pode ser recente e ainda que a praia deve ser mais estável, com raros eventos de tempestade. Na verdade, a quantidade de pellets na superfície do sedimento no pós-praia é pequena, ainda mais na sua porção inferior, ou seja, próximo ao limite inferior do pós-praia. Além disso, praias com berma são reflexivas e tenderiam a não acumular pellets no pós-praia, de forma que eles tenderiam a ser encontrados preferencialmente na faixa entremarés.

\section{horizontal) \\ 1.3. Avaliar a distribuição dos grânulos ao longo da praia (distribuição}

Os dados revelam que as áreas 2 a 6 apresentaram o maior número de pellets, referentes aos canais 1, 2 e 3 de Santos, um padrão provavelmente relacionado com a proximidade ao Porto e com a circulação marítima da Enseada. A área 1 constitui exceção pois, apesar de sua proximidade ao Porto, apresentou um baixo número de pellets em relação às outras áreas, já que sua faixa de praia vai se estreitando e, com isso, há um menor espaço para acúmulo de grânulos. Mesmo assim, de forma geral, observou-se uma densidade bem maior de pellets ao comparar-se com as áreas mais distantes do Porto de Santos. Já para o número absoluto de pellets (ST) o padrão geral se repete, com exceção dos picos nas áreas 5 e 6 e a grande quantidade na área 3, 
provavelmente devido à maior largura do pós-praia nestas áreas, levando à estimativa de uma maior densidade de pellets por faixa de praia.

Em relação às áreas amostrados em São Vicente, o que apresentou uma tendência no aumento da abundância de pellets foi o último $\left(15^{\circ}\right)$, correspondendo à porção final da enseada de São Vicente. Este aumento, embora não significativo, no número de pellets nesta área pode ser explicado pelo processo de circulação, devido a ventos e correntes no interior da enseada, o qual é predominantemente na direção sul (Harari et al., 2002), levando os pellets para a porção mais ao sul da baía. Além disso, foi observado que na margem leste dessas praias (áreas 11 e 12) há uma predominância de sedimento mais fino (argiloso) que na porção mais ao sul (áreas 14 e 15), devido à interrupção do aporte de sedimento pela feição natural do tômbulo e construção do emissário (Magini et al., 2007).

Além disso, fragmentos plásticos flutuantes geralmente depositam-se em praias estáveis e com grande influência de rios, refletindo suas características deposicionais (Santos et al., 2009). Entretanto, no Arquipélago de Fernando de Noronha, Ivar do Sul et al. (2009) encontraram pellets somente em praias a barlavento, ou seja, com características mais instáveis por estarem com a face virada ao oceano aberto e, portanto, sujeitas a ação direta de ondas e ventos do Oceano Atlântico Equatorial. Segundo Furness (1994), os pellets tendem a se acumular em regiões influenciadas por processos oceanográficos como frentes convergentes. Neste sentido a quantidade de pellets em uma dada praia parece depender tanto das características deposicionais quanto da possibilidade de aporte de pellets, via continente ou oceano.

Para verificar a associação entre as áreas de maior abundância dos pellets e as consideradas deposicionais os resultados desta amostragem foram ainda comparados com os dados existentes sobre células de deriva litorânea da região (Magini et al., 2007). Há um processo de sedimentação mais intenso na porção central da Baía (Praia de Itararé) devido à interação entre as ondas e correntes de sul e as correntes provenientes do Canal do Porto de Santos (Harari et al., 2002). No entanto, tal fato não foi corroborado pelos resultados obtidos no presente estudo. As áreas de maior densidade dos pellets (2 a 6) não corresponderam àquelas com intensos processos de deposição (porção central da enseada; Magini et al., 2007). Todas as praias de Santos são dissipativas (Magini et al., 2007)(praias com muita energia e com características morfológicas e texturais bem homogêneas) e não apresentam claramente uma gradação 
lateral (along-shore), prejudicando o entendimento de processos de sedimentação costeira por simples observações (Souza, 2007).

Como os pellets têm um comportamento hidro e aerodinâmicos diferente da areia não é possível compará-lo com os processos de sedimentação arenosos. No entanto, duas considerações podem ser feitas: como os pellets concentram-se na porção superior do pós-praia o mecanismo de transporte longshore não pode ser aplicado aqui, já que nessa região os processos predominantes são o eólico e ondas de tempestade (exceto em ressacas; Célia Regina Gouveia de Souza, com. pess.); a quantidade de pellets que chega na linha de deixa pode ser explicada por células de deriva, que determinam o transporte longshore, mas que deveria coincidir com as áreas de maior taxa de deposição de sedimentos, o que não ocorreu no presente estudo (a taxa de entrada dos pellets foi semelhante para toda a enseada). A zona de deixa marca o estirâncio superior naquele período de maré. Então essa seria a "marca" do transporte costeiro longitudinal (deriva praial). Acontece que a maior ou menor acumulação de sedimentos nessa zona, bem como as características texturais desses sedimentos e geomorfológicas da praia irão depender da zona da célula de deriva litorânea (erosão, deposição ou transporte) na qual esse sedimentos se encontram naquelas condições de contorno. Outro aspecto importante é o papel dos canais de saneamento das praias de Santos, que modificam as células de deriva litorânea.

Comparações entre a quantidade de resíduos encontrada nas pesquisas são complicadas devido às diferenças nas metodologias de estudo, características das praias e fatores ambientais influenciando a distribuição e acúmulo do material (Williams et al., 2005). Além disso, no presente estudo levou-se em consideração a distribuição dos pellets por profundidade no sedimento, variável encontrada em pouquíssimas pesquisas, como por exemplo em Kusui e Noda (2003) e McDermid e McMullen (2004).

Apesar das dificuldades na comparação entre as diferentes pesquisas, o presente estudo apresentou elevados índices de densidade de pellets: o maior valor médio encontrado em um transecto foi de 4.559 pellets $/ \mathrm{m}^{3}$ (referente a Área 3) e, extrapolando para a enseada toda, a quantidade estimada foi de 2.393.489.583 (considerando $7.5 \mathrm{~km}$ de praia). O valor médio obtido, considerando as 15 áreas, foi cerca de 1.000 pellets $/ \mathrm{m}^{3}$.

Pianowski (1997) obteve a maior média de 112.3/m, com um pico de quase 200/m em uma coleta (cada coleta amostrou 5 perfis de 1m de largura no pós-praia), mas nas outras praias amostradas as médias foram de apenas 1.06, 6.66 e 7.36/m. A 
concentração mais alta em praias foi encontrada por Gregory (1978) que chegou à estimativa de 100mil/m nas áreas de maior concentração. Vale ressaltar que a real quantidade destes resíduos no ambiente marinho como um todo está subestimada, já que nem todos os pellets perdidos alcançam a região costeira (Wetzel et al., 2004).

\section{Calcular a taxa de entrada dos grânulos nesta área}

A quantidade de pellets nas praias não pode ser extrapolada para estimar a quantidade que está sendo perdida ao ambiente, pois tanto processos de circulação hidrodinâmica costeiros como transporte offshore através de ressurgência podem carregar resíduos ao longo da costa para outras regiões, depositando nas praias somente uma parcela do total (Galgani et al., 1995b).

Existe uma preponderância das energias associadas aos efeitos de maré na circulação da área (Harari e Gordon, 2001). Correntes ao longo da costa transportam o material paralelo à costa que, combinadas com as marés cheias, resultam em deposição de resíduos plásticos ao longo das linhas de deixa (Corcoran et al., 2009). Como os pellets flutuam, acumulam-se nas praias sendo concentrados tanto em zonas estreitas ao longo de linha de deixa como espalhados para o pós-praia ou nas zonas de espraiamento (Gregory, 1977). Já que a deposição de pellets no ambiente praiano inicia-se com a chegada da maré alta, considerou-se que a quantidade no pós-praia deveria ser proporcional à quantidade encontrada na linha de deixa (pressupondo que todo o pellet que chega à praia não volta ao mar, apenas em casos de eventos extremos que promovam a remobilização de sedimento estocado no pós-praia), e por isso foi denominada como 'Taxa de Entrada'. No entanto, tal fato não foi corroborado pelos resultados, pois a taxa de entrada em relação às áreas amostradas apresentou um padrão homogêneo em condições meteorológicas estáveis.

Os resultados mostraram que houve uma maior taxa de entrada de pellets em 2 coletas específicas, a coleta III referente à estação do Inverno (média de 102 pellets/m², chegando a 377 pellets $/ \mathrm{m}^{2}$ ) e a coleta II do Outono (média de 45 pellets $/ \mathrm{m}^{2}$, chegando a 163 pellets $/ \mathrm{m}^{2}$ ). Em ambas situações estes resultados podem ser explicados por uma grande agitação do mar ('mar virado') na semana da coleta, provocada por ventos intensos, causando a deposição de mais grânulos na linha da praia.

De fato há relatos de que nos dias seguintes a períodos de chuvas intensas há um maior acúmulo de resíduos sólidos em praias (Williams e Simmons, 1997). Além 
disso, no Outono observou-se a maior discrepância entre as coletas, apresentando o maior índice na coleta II e o menor na I, esta última talvez pela grande calmaria do mar naqueles dias, com ventos praticamente nulos e pouca agitação da água. Resultados similares a este foram encontrados para a estação Primavera, que apresentou em média a menor taxa de entrada (para as 3 coletas) e, juntamente com a estação Verão, apresentou uma certa homogeneidade entre as coletas na abundância de pellets, evidenciando menor variação metereológica nos meses relacionados. A taxa média de entrada foi de 23,2 pellets $/ \mathrm{m}^{2}$ ( $\mathrm{n}=50.133$ pellets; área total amostrada=2.160 $\left.\mathrm{m}^{2}\right)$.

Na região ao largo da Enseada de Santos há grande influência dos ventos, enquanto que nos canais interiores rasos do sistema estuarino predominam as correntes de maré. Os efeitos de flutuação do nível médio do mar são associados a eventos meteorológicos extremos, os quais possuem importantes conseqüências nos sistemas de correntes marítimas (Harari et al., 2002). É importante notar que enquanto as marés apresentam amplitude típica na área de $100 \mathrm{~cm}$, efeitos meteorológicos extremos chegam a provocar aumentos de 50 a 100cm no nível médio do mar; no entanto, na ausência de efeitos meteorológicos significativos, a circulação de maré pode ser considerada como uma boa aproximação da circulação marítima total (Harari et al., 1997).

Esse variação temporal também foi encontrado em outros trabalhos. Shiber (1982) observou nas praias da Espanha a maior quantidade de pellets nos meses de Inverno, principalmente após eventos de tempestade, quando a intensidade do vento era maior e o mar estava mais turbulento. Além disso, devido aos ventos fortes típicos destes meses, os pellets que chegam com as ondas são rapidamente secos e espalhados para regiões mais altas da praia, dificultando a estimativa da real taxa de entrada no ambiente. Moore et al. (2002) também observaram uma maior abundância de resíduos sólidos nas águas costeiras logo após eventos de tempestade, em torno de duas vezes a taxa observada anteriormente em seus estudos. Para peso, essa relação não foi observada, evidenciando uma maior quantidade de resíduos de pequeno tamanho.

Padrões de flutuação sazonal na abundância de resíduos sólidos em praias foram encontrados em outros estudos. Wetzel et al. (2004) salientaram que os resíduos depositados e, posteriormente, enterrados nas praias estão sendo novamente expostos durante o Inverno devido às fortes ondas típicas deste período. Assim são explicados os processos de sedimentação costeira em praias altamente dinâmicas, onde há deposição de areia nas estações da Primavera e Verão e erosão nos outros meses do ano. Além disso, fragmentos flutuantes são mais susceptíveis à força de ventos e correntes de 
superfície, podendo ser dispersos a longas distâncias (Debrot, 1999) e/ou ainda depositados em praias a barlavento (Ivar do Sul et al., 2009) ou em situações de tempestade. Tais características podem auxiliar no transporte de pellets por longas distâncias antes de serem depositados, fato que explica a grande concentração na praia da Boa Viagem (densidade média de 100 pellets $/ \mathrm{m}^{2}$ ), já que não existem fontes locais próximas (Costa et al., 2009).

Pianowski (1997), no entanto, em seu estudo realizado na zona entremarés e linha de deixa em praias no litoral do RS, mostrou que a ocorrência de pellets se deu ao longo de praticamente todo o período amostrado, não apresentando um padrão em relação aos meses do ano. Bjorndal et al. (1994) evidenciaram que os processos de deposição de pellets em áreas costeiras e seu possível retorno aos oceanos, relacionados principalmente com eventos de tempestades e marés altas, acabam mascarando diferenças sazonais tanto na taxa de entrada quanto na quantidade de pellets no sedimento naquele período, fato também relacionado com o grande tempo de decomposição dos plásticos e sua longa permanência nos oceanos antes de ser depositados nas praias.

A estimativa da taxa de entrada de pellets nas praias de Santos pode estar subestimada por dois motivos principais: primeiro que a cidade apresenta praias altamente utilizadas durante todos os meses do ano, principalmente para práticas esportivas, soterrando os pellets; segundo que, nos meses de Verão, há ainda limpezas periódicas da linha de deixa devido à chegada de turistas, o que acaba retirando alguns pellets em meio aos outros resíduos. Estes dois fatores somados dificultam a visualização e posterior coleta do material. Quando as praias são mais “preservadas” os pellets são mais facilmente encontrados (Shiber, 1987; Pianowski, 1997).

\section{Descrever as características dos grânulos}

\subsection{Composição Química}

Dos 500 pellets analisados, quase $80 \%$ eram PE, mostrando significativa parcela composta por este material. Cerca de 18\% eram PP e o restante era uma mistura de PE e PP. Resultados semelhantes foram observados por Pianowski (1997) que, de 14 pellets analisados, 4 eram PEAD, 6 PEBD, 3 PP e 1 não identificado. Karapanagioti e Klontza (2007) verificaram uma porcentagem de PE de 60\%, relativamente alta em 
comparação com PP (20\%) e outros polímeros (20\%). Gregory (1977), por análises de FTIR, detectou que a maior proporção dos pellets eram PP e PE, em relação aos pellets de PS e PVC.

Em 1979, Shiber encontrou pellets de PEAD, Polimetilmetacrilato (PMMA) e PS em praias do Líbano. Em 1982 observou nas praias da Espanha que 87\% era constituído de PEBD e 8\% PEAD. Em 1987, ampliando a área amostrada na costa da Espanha, houve um predomínio de PE, assim como nos estudos anteriores (Shiber, 1979, 1982). Neste estudo, Shiber relacionou cores à composição química dos pellets, determinando que os brancos e amarelos opacos, verdes e alguns vermelhos eram PEBD (assim como pellets alaranjados). Alguns vermelhos e azuis eram PEAD, alguns alaranjados eram PP e outros vermelhos eram misturas de PP e PE, mas estes eram extremamente raros. Ainda pellets bem claros e transparentes geralmente eram feitos de etil vinil acetato. PS neste estudo não foi encontrado. Como polímeros de PE foram observados em maiores concentrações em diferentes localidades estima-se a probabilidade da maior produção de PE em relação aos outros polímeros e ainda que os locais amostrados tenham uma maior proximidade com indústrias produtoras deste tipo de polímero.

Karapanagioti e Klontza (2007) submeteram pellets a um teste de densidade através do grau de adsorção de fenantreno e compararam com pellets virgens. Para isso utilizaram água pura e uma solução de $45.5 \%$ por volume de álcool isopropílico, apresentando densidade de 1 e $0.95 \mathrm{~g} / \mathrm{ml}$, respectivamente. A maior parte afundou (92\%), embora o PP devesse flutuar (0.90-0.91 g/ml)(Spinacé e De Paoli, 2005). Isso indica que os aditivos alteram a densidade dos pellets e que este método de análise de densidade não poderia ser aplicado em materiais amostrados de praias, ou seja, de origem desconhecida.

No entanto, no presente estudo, a baixa taxa de erro obtida entre as análises de composição dos pellets por densidade e por Ramam (em torno de 10\%) justifica a utilização desta metodologia. Ainda, apesar do método por densidade não ter demonstrado ser capaz de detectar pellets compostos por mistura de polímeros ele apresenta vantagens significativas em relação ao Ramam, como seu baixíssimo custo, a rapidez nos resultados, a independência de equipamentos e disponibilidade de técnicos para a realização das análises e ainda a classificação dos pellets em PEAD e PEBD, já que quase $80 \%$ corresponde a polímeros de PE. 


\subsection{Caracterização morfológica}

Não foi observado nenhum padrão claro entre as características morfológicas dos pellets e profundidade, área e estação do ano, ainda que diferenças significativas tenham sido encontradas. Entretanto, destacam-se aqueles coletados na profundidade de 30-40cm, na qual aparentam apresentar uma "assinatura": foram considerados cilíndrico-achatados apesar de apresentarem os maiores valores em altura e os menores em diâmetro. Isso indica que podem haver fontes variáveis ao longo do tempo (já que os pellets são diferentes entre as profundidades) e que os processos de redistribuição deles ao longo da praia atuam de maneira distinta para pellets com características diferentes.

\section{Tamanho}

De uma maneira geral, os pellets apresentaram um padrão homogêneo de tamanho, concentrando os valores em torno de 2,5 a 3mm em altura e de 3,5 a 4,2mm em diâmetro. Algumas relações significativas foram obtidas: para altura, os maiores pellets foram encontrados no Inverno, quando ventos mais intensos e ondas mais fortes podem trazer partículas maiores para a praia; já os menores pellets foram coletados na Primavera, cujos meses apresentam raros eventos de tempestade; para as estações Verão e Outono a altura dos pellets apresentou valores intermediários. Além disso, os maiores pellets foram coletados nas áreas 3 e 4, referentes a porção central da enseada, local onde há processos de deposição de sedimento mais intensos (Magini et al., 2007). Para diâmetro foi obtida correlação entre os maiores valores no Verão, ao contrário do esperado, e não apresentou diferenças entre as 6 áreas de coleta.

Resultados semelhantes foram encontrados em diversos trabalhos. Gregory (1977) encontrou pellets variando de $4 \mathrm{~mm}$ a $6 \mathrm{~mm}$ ou mais em diâmetro e entre 2 e $5 \mathrm{~mm}$ em altura. O diâmetro medido por Shiber (1979) também ficou em torno de 2 a 5mm. Em 1982, os pellets mediram entre 3 e 4,5mm de diâmetro (Shiber, 1982). Já em 1987, Shiber observou que mais da metade dos pellets apresentaram diâmetro médio de $3.2 \mathrm{~mm}$ e altura de $3.7 \mathrm{~mm}$, cerca de $1 / 4$ tinham diâmetro médio de $3.8 \mathrm{~mm}$ e $10 \%$ mediram 3.6mm em diâmetro. Em outros estudos, o tamanho dos pellets variou de 1 a 5mm (Karapanagioti e Klontza, 2007), e Kusui e Noda (2003) obtiveram um tamanho médio de 4x4mm (em altura e diâmetro). 


\section{Forma}

Cerca de $80 \%$ dos pellets encontrados enterrados no sedimento apresentaram formato cilíndrico achatado e 10\% esférico achatado; para aqueles coletados na linha de deixa, mais de $50 \%$ apresentava o primeiro formato e cerca de $30 \%$ apresentava o segundo. A significativa porcentagem de pellets com essas formas reflete a grande parcela da indústria plástica produzindo matéria-prima nas formas cilíndrica e esférica achatada.

Gregory (1977) encontrou vários tipos de formas de pellets nas praias da Nova Zelândia, dentre as quais destacou-se as ovóides, esféricas e os discos cilíndricos. Shiber (1979) também encontrou grande variação na forma dos pellets coletados na linha de deixa ao longo de toda a costa do Líbano, mas a maior parte era oval à esférico. Em 1987, Shiber observou que mais da metade tinha formato cilíndrico, cerca de 1/4 eram esféricos a ovais; $10 \%$ eram esféricos achatados, e o restante apresentou forma variada, com destaque para o formato cúbico. Pianowski (1997) também observou que a maior parte apresentava formato cilíndrico e Costa et al. (2009) encontraram pellets cilíndricos, ovais e ainda disformes.

\section{Cor}

Apesar dos resultados estatísticos terem apontado diferenças significativas não foi observado um padrão claro para a distribuição das cores em profundidade, áreas de coleta e estações do ano.

A coloração dos pellets também apresentou homogeneidade: cerca de 60\% apresentou um padrão de cor em tons de amarelo claro e o restante em tons de marromalaranjado. O primeiro padrão de cores geralmente é aquele observado quando os pellets são produzidos e não pigmentados, no geral em tons bem claros e transparentes (Karapanagioti e Klontza, 2007). Os pellets coloridos (pigmentados) foram raramente encontrados, tornando sua contabilização irrisória neste estudo. Já os pellets que apresentaram o segundo padrão de coloração mais abundante, em tons de marromalaranjado, podem ter sofrido processos de oxidação por raios UV (fotooxidação)(Karapanagioti e Klontza, 2007) de forma que essa coloração pode estar relacionada com o tempo de exposição ao ambiente. O “amarelamento” dos pellets pode ser um indício de degradação, tendendo à colorações marrom-alaranjado ao longo do tempo (Baum, 1974). Além disso, processos de intemperismo ao longo do tempo podem afetar tanto a forma como a coloração dos pellets, fato encontrado no presente estudo 
(alta taxa de PEs amarelados com certo grau de degradação), sugerindo que pellets “velhos” (desgastados) podem ser um problema de origem antiga e não recente (Miller et al., 2003).

O padrão de coloração dos pellets observado neste estudo mostrou-se semelhante com os resultados encontrados em outros para o ambiente marinho e costeiro, incluindo praias. Karapanagioti e Klontza (2007) encontraram que 60\% dos pellets amostrados em praias da Grécia eram claros, 20\% amarelos e 20\% marromalaranjados e ainda observaram que cerca de $10 \%$ dos pellets marrom-alaranjados tinham piche em suas superfícies, sugerindo que essa coloração poderia ter sido originada pela transferência do material aderido ao polímero. Gregory (1977) observou que pellets translúcidos e sem coloração foram os mais comuns e que os coloridos foram mais encontrados próximos à áreas industriais.

Alguns pesquisadores, entretanto, levantaram resultados discrepantes com o encontrado no presente estudo. Pianowski (1997) revelaram que cerca de 90\% dos pellets encontrados eram de coloração branca opaca, 5\% preta e 5\% amarela. Shiber (1979) geralmente encontrou pellets com aspecto branco opaco ou claro transparente. Shiber (1982) revelou que 87\% era constituído por pellets opacos, amarelados e laranjaamarronzados, $8 \%$ eram brancos, $4 \%$ claros à transparentes e apenas $1 \%$ eram coloridos. Em estudos posteriores, Shiber (1987) encontrou cerca de 56\% de pellets branco opaco e 26\% alaranjado; o restante apresentava cores variadas (amarelo, azul, verde, marrom, laranja e cinza). Costa et al. (2009) também observaram pellets com cor branca e em tons perolados, acinzentados e amarronzados.

\section{Desgaste}

De uma forma geral os pellets apresentaram-se bem conservados, a maioria apresentando baixos graus de incrustação, rebarba e craquelamento. No entanto, uma parcela significativa dos pellets coletados na linha de deixa foi classificada na taxa de 80-100\% de alteração da superfície, evidenciando que as partículas que estão sendo depositadas estão mais alteradas (sofreram mais desgastes e/ou incrustação) do que aquelas que já estão soterradas há algum tempo. Este resultado aponta para a hipótese de que os pellets já enterrados foram rapidamente depositados na praia e, por ventos fortes e marés muito altas, foram levados às partes mais altas e soterrados, ali permanecendo por um longo período, sem sofrer grandes alterações na superfície. Já os pellets mais 'recentes' (coletados na linha de deixa) também foram despejados no 
ambiente há algum tempo, mas por falta de processos mais intensos na região costeira não foram rapidamente depositados e soterrados na praia, ou ainda foram remobilizados sofrendo mais desgastes e/ou incrustações no ambiente marinho.

Esta hipótese está embasada em resultados obtidos a partir de uma série de estudos. Segundo Wilber (1987), a superfície erodida ou grau de incrustação dos pellets devido a processos de intemperismo pode ser um indício do tempo de exposição deles ao ambiente marinho. Mais de $80 \%$ dos pellets coletados em seu estudo apresentaram evidências de exposição prolongada na superfície marinha. Os níveis de erosão dos pellets podem estar relacionados com o grau de exposição à água do mar, sol e vento (Karapanagioti e Klontza, 2007). Esse fato pode estar de acordo com o tempo de permanência do pellet no ambiente aquático antes de ser depositado na praia (Shiber, 1982).

Em praias os plásticos sofrem processo de erosão devido a fatores como raios UV, vento, maré, correntes e ação de ondas. Um estudo sobre a textura dos resíduos plásticos em praias demonstrou que esses sofrem tanto processos químicos quanto mecânicos (Corcoran et al., 2009). As texturas das partículas plásticas foram obtidas durante impactos mecânicos entre as suas superfícies e estas com grãos de areia e finas partículas de sedimento, derivados de intemperismo químico da areia, que aderiram à superfície dos plásticos. A tendência de fraturas lineares e bordas das partículas apresentarem maior quantidade de produtos de oxidação indica que essas fraturas criadas por erosão mecânica são locais favoráveis para ocorrência de intemperismo químico. Oxidação por exposição aos raios UV, somados a processos abrasivos adicionais, resultam em rupturas ao longo de fraturas, eventualmente levando à fragilização do plástico.

Gregory (1977) também observou que a maioria dos pellets encontrados aparentou estar pouco quebradiço, assim como os pellets coletados em praias da Espanha (Shiber, 1982), apresentando-se relativamente preservados, com pouco material aderido e inscrustação por biota, apesar de apresentarem piche com certa freqüência (tornando-os acizentados). Já em 1987, Shiber observou que muitos apresentaram alto grau de intemperismo e piche aderido à superfície. 


\section{Identificar as possíveis fontes de emissão de grânulos para a Enseada de} Santos

Estudos sobre resíduos sólidos em praias e regiões costeiras têm sido amplamente desenvolvidos com o intuito de estimar a quantidade e composição desses materiais descartados pelo homem no ambiente. No entanto, estes estudos não possibilitaram ainda o desenvolvimento de uma metodologia para investigar a movimentação e as possíveis fontes desses resíduos (Wilson e Randall, 2005). Técnicas estatísticas e modelagem numérica têm se mostrado úteis em determinar as fontes de emissão, mas são dependentes de estudos de base ou testes específicos da área para confirmar os resultados (Wilson e Randall, 2005).

Padrões variáveis de movimentação de resíduos podem estar relacionados às características de dispersão de determinado item, à natureza física da área (como zonas de deposição ou paredes verticais), perdas do sistema ou à taxas instáveis de recuperação do material (Wilson e Randall, 2005). Partículas pequenas são mais difíceis de recuperar em estudos de monitoramento da movimentação de resíduos sólidos em ambiente estuarino-costeiro, pois além de serem menos visíveis acumulam-se com materiais de refugo ao longo da costa. Além disso, materiais flutuantes alcançam áreas mais distantes do ponto de emissão em um determinado período (Wilson e Randall, 2005). Em praias esses pequenos fragmentos são 'perdidos' da superfície alojando-se entre pedras e/ou grãos de areia (Williams e Tudors, 2001).

Os resultados de dispersão de pellets na Enseada e no Estuário de Santos e São Vicente através de modelagens numéricas (Harari e Gordon, 2001) mostraram que, de acordo com os pontos de emissão, os pellets apresentam comportamentos diferentes. Para as liberações no interior do estuário, os pellets tenderam a concentrar-se na mesma área, devendo sair para a enseada apenas em situações de enxurrada e intensas correntes de maré vazante, desaguando grandes quantidades na região costeira de uma só vez. Em relação aos pontos próximos à boca do Canal de Santos, os pellets ali lançados, a curto prazo, concentram-se nas duas extremidades da enseada (fato que corrobora os resultados obtidos no presente estudo) e, a médio e longo prazos, são depositados ao longo da linha de deixa de toda a baía (de acordo com os resultados obtidos para taxa de entrada). Há ainda a previsão de uma pequena fuga de pellets para fora da enseada. Já para os pontos amostrados mais ao largo da baía, uma parte dos pellets foi exportada 
para áreas ao redor, como o Guarujá, por exemplo, ou ainda regiões mais longínquas do litoral paulista (locais não mostrados no mapa), mas grande parte também alcançou as praias de Santos e São Vicente cujos processos de deposição foram auxiliados provavelmente por células de deriva litorânea (Pianowski, 1997), formadas por influência de correntes de maré, ondas e vento (Magini et al., 2007). Foram descobertas duas células de deriva atuantes na Enseada de Santos, uma maior na porção central da baía, girando no sentido horário (Célula Santos) que, juntamente com correntes provenientes de Canal de Santos, levam a uma maior deposição de sedimentos nessa região; e uma outra célula de deriva (Célula Itararé) atua nas praias de São Vicente que, também influenciadas pelas correntes oriundas do Canal de São Vicente, atuam no sentido anti-horário, acarretando numa maior deposição de sedimentos na porção mais ao sul da baía (Magini et al., 2007), corroborando os resultados encontrados no presente estudo.

Ainda pode-se inferir que o estuário deve ser a maior fonte dos pellets, mas provavelmente não a única; a maior parte dos pellets fica nas margens do estuário, como pode ser observado nos pontos 1 e 2, em qualquer mês. Por outro lado, condições de enxurradas que possam levar pellets para a boca do canal através de fortes correntes, podem acarretar na saída dos pellets do estuário e o posterior espalhamento dos pellets por toda a orla praiana, espalhando as substâncias por áreas maiores (Harari e Gordon, 2001), como pode ser observado no ponto 3 e 4 em qualquer mês. Há também a possibilidade de navios estacionados ao largo da enseada serem fontes de pellets, especialmente em condições de inverno, com grande número de frentes frias, como pode ser observado nos pontos 5 e 6, para o mês de agosto de 2008. Em relatos informais de moradores da região foram ressaltados o uso de pellets para a lavagem de porões de navios, através do jateamento com os pellets, por ser um material mais barato e leve do que a areia no processo de adsorção de compostos orgânicos.

Estes resultados podem ser explicados através dos estudos desenvolvidos na região por Harari e Gordon (2001). Como os campos hidrodinâmicos utilizados na modelagem foram bastante realísticos para a região, com marés e ventos típicos da área, foi possível quantificar o alcance típico da dispersão das partículas. Nos instantes de máxima enchente (ou vazante) os efeitos de advecção são máximos, e os deslocamentos dos centros das manchas em relação aos pontos de descarga são maiores. As correntes de maré são tão intensas na boca do Canal do Porto que chegam a advectar as partículas por distâncias consideráveis. Nos períodos com correntes permanentes adicionadas às 
correntes de maré, nota-se um significativo aumento da dispersão de materiais. Esses efeitos são intensos tanto no caso das correntes de deriva vazantes, que proporcionam a dispersão de materiais desde o Canal do Porto até a Baía de Santos, como no caso das correntes de deriva enchentes, que provocam uma intensa dispersão dos materiais em direção às praias. Na Boca do Canal do Porto o material descarregado rapidamente se dispersa mesmo que seja somente sob o efeito das marés, mas pode então atingir outras regiões. Na realidade, enquanto o fluxo e refluxo das marés produzem uma dispersão limitada dos materiais, o efeito adicional de correntes de deriva pode impactar áreas relativamente distantes dos locais de descarga das substâncias.

Em relação às fontes externas da enseada, não há evidências de que o grande aporte de pellets encontrados nas praias de Santos tenha sido originado de outras regiões, isto porque, por observações pessoais, foi encontrada uma quantidade extremamente pequena de pellets nas praias de municípios próximos, como Maresias, Caraguatatuba e Ubatuba, além de não haver registro de indústrias produtoras nestas áreas. Ressalta-se também o provável aporte de pellets para o Parque Marinho da Laje de Santos já que, em algumas situações, significativas quantidades deste material podem ser levadas para áreas mais distantes da costa. Distante cerca de $37 \mathrm{~km}$ da costa e apresentando uma área em torno de $50 \mathrm{~km}^{2}$, que abriga diversas espécies de pássaros e peixes, entre outras. Neste Parque são desenvolvidas atividades turísticas e esportivas (como mergulho autônomo) de forma controlada, e têm sido protegida da intervenção e ocupação humana (Harari et al., 2000). A entrada de pellets nesta região pode causar graves impactos ecológicos no equilíbrio do ecossistema, acarretando inclusive prejuízos econômicos, ao interferir no setor pesqueiro e turístico.

Outras possíveis fontes não foram encontradas nesse estudo. Apesar de a Estação Municipal de Tratamento de Esgoto e o sistema de canais de Santos não terem sido amostrados, acredita-se que nestes locais não existam pellets, já que as indústrias situam-se às margens da cidade, na região estuarina, juntamente ao Porto de Santos e aos terminais marítimos. Por esse motivo, associado com a ausência de indústrias de transformação na área de estudo, também não há tráfego terrestre no transporte deste material no interior das cidades, diminuindo ainda mais a probabilidade de emissões urbanas de pellets para a Enseada de Santos.

Identificar de qual fonte os resíduos sólidos são provenientes é um objetivo altamente difícil (Williams et al., 2005; Santos et al., 2009). As possíveis fontes podem apenas ser estabelecidas após um minucioso levantamento sobre as características do 
material em questão (Williams et al., 1999). Não existe uma metodologia que permita aos pesquisadores relacionar os resíduos à sua fonte, mas para ajudar nesse processo são necessários identificar a aplicação do material e medir sua quantidade no ambiente (Tudor e Williams, 2004), além de atentar à distribuição espacial dos resíduos em relação às fontes suspeitas, estabelecer relações de causa-efeito e atentar para a presença de organismos incrustantes (Santos et al., 2009). Em praias do Nordeste do Brasil quantidades insignificantes de plásticos incrustados foram encontrados, o que demonstra um pequeno tempo de residência no oceano e portanto a baixa probabilidade de ter sido originado por fontes marinhas (já que aproximadamente 50\% dos resíduos encontrados em praias em algumas áreas tropicais contém organismos incrustantes)(Santos et al., 2009).

No entanto, a maior parte dos estudos sobre as possíveis fontes de emissão de pellets para o ambiente são concordantes em diversas hipóteses. Pesquisadores atentaram para o fato de que as principais fontes de pellets para o ambiente aquático (Gregory, 1977) e praiano (Shiber, 1979, 1982 e 1987) são originadas por derramamentos acidentais em áreas portuárias (Costa et al., 2009) e por despejos industriais nos rios ou diretamente no ambiente marinho. A abundância encontrada variou bastante entre as praias amostradas por Gregory (1977), mas concentrou-se naquelas mais próximas às áreas industriais (excedendo $40 \mathrm{mil} /$ metro linear), apesar de ter sido observado em praias remotas de contaminação industrial (em torno de 10/m). Atividades costeiras pouco planejadas, como turismo, livre navegação e grande desenvolvimento destas regiões, também podem ser fontes de resíduos marinhos (Santos et al., 2009).

Nos EUA, Hays e Cormons (1974) encontraram pellets ao redor da saída das tubulações de esgoto e em regiões à juzante dos rios próximos às indústrias plásticas, assim como em praias relacionadas ao estuário da região. Partículas similares encontradas nas diferentes áreas amostradas sugerem que os pellets, oriundos dos efluentes das indústrias, foram levados rio abaixo, alguns depositando-se na boca do estuário e a maior parte sendo carregada para as áreas costeiras. Além desse estudo, foi desenvolvido na Califórnia um projeto sobre o descarte impróprio de plásticos, o Plasctic Debris Project (Gordon, 2006), chegando à conclusão de que os pellets acumulados nas praias foram descartados por indústrias das áreas urbanas da região e alcançaram o sistema marinho e costeiro através dos sistemas de drenagem de água da chuva (Moore et al., 2002). 
Apesar de a maior parte dos trabalhos correlacionar a abundância dos pellets com áreas industriais e altamente povoadas (Gregory, 1978; Shiber, 1979, 1982 e 1987; Khordagui e Abu-Hilal, 1994; Moore et al., 2001a; Costa et al., 2009; Santos et al., 2009), outros encontraram-nos em altas densidades em praias distantes e preservadas (Gregory, 1983 e 1999; McDermid e McMullen, 2004, Costa et al., 2009; Ivar do Sul et al., 2009). A maior quantidade de pellets encontrada por Pianowski (1997) deveu-se provavelmente à conservação da praia, apresentando um baixo grau de soterramento dos pellets por pisoteio. No entanto, encontraram relação entre a maior quantidade de pellets e a maior proximidade de portos e ainda apontaram para a limpeza de containeres em alto mar como outra provável fonte de emissão dessas partículas para o ambiente. Já em Fernando de Noronha (Ivar do Sul et al., 2009) a principal fonte é o mar, cujos pellets flutuantes são depositados nas praias pelos ventos e correntes de superfície (influenciada pela Corrente Sul-Equatorial).

Diante de todas essas informações, acredita-se que as prováveis fontes de emissão de pellets no interior do Estuário de Santos e São Vicente sejam o Porto de Santos, a Alemôa, que inclui o terminal da Braskem e a Pepasa, e a Polietilenos União (em Cubatão), emissões que aumentam a probabilidade da existência de uma alta concentração de pellets no interior do estuário. O Porto pode ser fonte dos três tipos de polímeros encontrados nas praias (PP, PEAD e PEBD), através do manuseio de sacarias de pellets nos processos de carregamento e descarregamento entre os navios e os caminhões. O Terminal da Braskem pode estar emitindo pellets de PP, produzidos na unidade de Paulínia e sendo exportados por seu terminal. Em relação às indústrias da região, como a Pepasa, que produz PP e PEAD, e a Polietilenos União, que produz PEBD, também podem ser fontes dos pellets encontrados nas praias de Santos. Não foram encontrados os polímeros produzidos pela Dow Química e, portanto, esta não pode ser uma fonte de pellets à região. Além desses polímeros, aqueles identificados como mistura de PE e PP podem ter sido originados da Pepasa, que também produz polímeros com mistura, ou ainda por processos de reciclagem. Já as prováveis emissões ao largo da enseada devem ser oriundas dos processos de lavagem de porões e tanques de navios, por ser um material mais barato e leve do que a areia, informação levantada a partir de relatos informais de moradores da região e ainda por Pianowski (1997). 


\section{Controle e Gestão}

Por esses resultados, estudos posteriores devem ser realizados no âmbito de investigar a quantidade e distribuição dos pellets no Estuário de Santos-São Vicente (devido também à escassez desses estudos em estuários), nas praias do Guarujá, Praia Grande e Bertioga, e ainda na camada superficial da água das áreas mais externas da Enseada, incluindo a Laje de Santos. Além desses, estudos relacionados com a toxicidade dos pellets também devem ser considerados, uma vez que diversas pesquisas apontaram para os impactos que essas substâncias tóxicas podem causar nos organismos. Deve-se atentar ainda para o fato de que quase $80 \%$ dos pellets nesta região eram compostos por PE, polímero que pode concentrar até 2x mais esses poluentes em relação ao PP (Karapanagioti e Klontza, 2007).

O controle dos pellets é responsabilidade das indústrias plásticas que, segundo Miller et al. (2003), parecem desconhecer os impactos negativos originados pelos plásticos no ambiente assim como os benefícios econômicos na redução das perdas e na reciclagem do material 'perdido'. Para garantir a efetividade de estratégias na redução de emissão de resíduos para o ambiente são necessários um programa de longo prazo de monitoramento de emissões, penalidades para despejos ilegais, cooperação internacional na área e reciclagem dos plásticos (Kusui e Noda, 2003). Redford et al. (1997) também apresentaram uma série de recomendações para redução de perdas de pellets pelas indústrias do Reino Unido ao ambiente aquático, como aprimorar as operações rotineiras e práticas de gestão, embalar e manusear adequadamente a carga, implementar sistemas de contenção e ainda reciclar os pellets perdidos. No entanto, não existe atualmente programas ambientais para o monitoramento de partículas plásticas no ambiente marinho (Gordon, 2006). Já a reciclagem dos pellets pode e deve ser feita.

Uma síntese da teconologia da reciclagem de polímeros foi efetuada por Spinacé e De Paoli (2005), que atentaram para a importância deste mecanismo como uma das alternativas mais viáveis para minimizar os impactos ambientais causados pela disposição inadequada deste material. Segundo esses autores, diversos aspectos motivam a reciclagem dos resíduos poliméricos: a economia de energia, a preservação de fontes esgotáveis de matéria-prima, a economia com a recuperação de áreas impactadas pelos resíduos, o aumento da vida útil dos aterros, a redução de gastos com a limpeza e saúde públicas e a geração de emprego e renda. De um modo geral, todos os tipos de polímeros têm sido reciclados, tanto os industriais quanto os pós-consumo 
(Spinacé e De Paoli, 2005). No Brasil, o PE e o PP são os polímeros reciclados por um maior número de empresas, e mais da metade delas reciclam entre 20 a 50t/mês (Spinacé e De Paoli, 2005).

Uma outra alternativa para a redução do impacto causado pelos pellets no ambiente é a produção de materiais que sejam menos poluentes, como o Plástico Verde desenvolvido pela Braskem em 2007. Esse material, chamado de biopolímero (oriundo de fonte vegetal) é produzido com eteno a partir do álcool da cana-de-açúcar (etanol), que é uma fonte renovável, ao contrário do petróleo, e permite a obtenção de qualquer tipo de polietileno com características equivalentes ao PE convencional. Além disso, cada kg de PE verde fixa 2,5kg de $\mathrm{CO}^{2}$ da atmosfera, colaborando com a redução do efeito estufa e aquecimento global. Estes polímeros estão sendo testados para aplicação na indústria automobilística, de embalagens alimentícias, comésticos e higiene pessoal. A produção deste material está estimada para 200mil t/ano e seu início previsto para 2010 na Unidade de Triunfo-RS ${ }^{14}$.

Além deste tipo de polímero, destaca-se ainda a produção dos plásticos biodegradáveis, derivados de outras fontes vegetais, como o amido (de mandioca, milho ou batata), ou compostos por aditivos que auxiliam no processo de degradação quando expostos à processos de imtemperismos e/ou por ação de decompositores. Outro material produzido com esse intuito é o plástico hidrosolúvel, à base de álcool polivinílico que se desmancha em contato com a água sem deixar resíduos tóxicos. A principal aplicação é no envase de detergentes, desinfetantes e saponáceos em pó, que podem ser diretamente jogados na máquina de lavar roupa ou no vaso sanitário ${ }^{15}$.

Uma outra alternativa é o desenvolvimento de programas que visam o incentivo à não-emissão dos pellets. O Conselho Americano de Plásticos (CAP), em parceria com a Sociedade das Indústrias Plásticas dos EUA (SPI), está promovendo um programa para a ‘perda zero’ de pellets pelas indústrias de produção e processamento de resinas na Califórnia, através da revisão do manual Operation Clean Sweep (OCS) e desenvolvimento de materiais de treinamento colocados no site do programa ${ }^{16}$ (Gordon, 2006). Essas organizações estão educando os produtores, processadores, transportadores

\footnotetext{
${ }^{14}$ www.braskem.com.br/plasticoverde/principal.html

${ }^{15}$ www.resbrasil.com.br

${ }^{16}$ www.opcleansweep.org
} 
e embaladores de resinas sobre os possíveis impactos que o manuseio inadequado desse material pode acarretar no ambiente marinho e informando sobre as BPMs (Best Managment Practices) para se alcançar ‘perda zero’ de pellet, o que poderia ser aplicado no Brasil.

A CFECA (California Film Extruders and Converters Association) lançou um programa de certificação, o EPR (Environmentally Preferred Rating), que consiste em um programa independente de auditoria para verificar, com respeito à contaminação por pellets, se as indústrias plásticas estão adotando o manual OCS e se estão de acordo com as melhores práticas de manejo (Gordon, 2006). Na Escócia, o Grupo de Qualidade de Efluentes Industriais juntamente com a Agência de Proteção Ambiental Escocesa (SEPA) estão trabalhando com as indústrias plásticas para a tomada de medidas na redução da perda de pellets ao ambiente, como a instalação de interceptores que previnam o despejo das partículas no sistema de drenagem e ainda a inspeção regular de veículos (em relação ao bom funcionamento das válvulas)(Miller et al., 2003).

No Brasil, como estudos relacionados aos impactos dos pellets no ambiente são incipientes, ainda não existem programas e projetos desenvolvidos a longo prazo para monitorar e mitigar essas possíveis emissões. No entanto, atualmente cada setor específico relacionado com a cadeia produtiva dos pellets plásticos (como as indústrias de $2^{\mathrm{a}}$ e $3^{\mathrm{a}}$ gerações e seus respectivos meios de transporte e terminais marítimos), juntamente com as atividades portuárias, são obrigados a apresentar programas ambientais para evitar e mitigar possíveis impactos, ou ainda formas de compensar os inevitáveis. Sendo assim, ressalta-se a importância da inclusão de mecanismos de contenção, monitoramento e reaproveitamento de pellets nos projetos e programas ambientais destas indústrias, como exemplo de outros países.

Em Santos, a Diretoria Executiva da Companhia Docas do Estado de São Paulo (CODESP) aprovou no dia 09 de junho de 2009 os estudos para a criação do Instituto Porto de Santos, entidade de direito privado, sem fins lucrativos, que coordenará a proposição e a execução de projetos em diversas áreas, inclusive meio ambiente. Nesse sentido, vê-se a oportunidade da inclusão de projetos ambientais para que o problema dos pellets na região possa ser resolvido. 


\section{CONSIDERAÇÕES FINAIS}

O crescente número de resíduos plásticos, especialmente pellets, nos oceanos têm levado à necessidade do desenvolvimento de pesquisas adicionais sobre os seus possíveis impactos nos ecossistemas aquáticos e costerios mundiais (Gordon, 2006). Para o litoral brasileiro esta situação não é diferente, destacando-se a região da Baixada Santista pela crítica situação em que se encontra (dado os resultados do presente estudo).

De uma maneira geral, os dados levantados na presente pesquisa são inovadoras, principalmente pela quantidade registrada para a área de estudo em comparação com os registros existentes em literatura. Os pellets foram encontrados a até $2 \mathrm{~m}$ de profundidade, concentrando-se na porção mais superior do sedimento e ainda na porção mais alta do pós-praia (mais distante da linha d’água). Todos os trabalhos que buscaram quantificar os pellets em praias só consideraram a parte mais superficial do sedimento, ignorando a possibilidade dessas partículas ocorreram em maiores profundidades. A distribuição ao longo da enseada mostrou que os pellets se concentraram nas áreas mais próximas ao Estuário de Santos, fato relacionado principalmente com a circulação da baía e correntes provenientes do canal. A taxa de entrada não mostrou um padrão entre as áreas de coleta e as estações do ano, mas o maior número de pellets foi encontrado após eventos de tempestades. A maior parte dos polímeros foi composta por Polietileno (PE) e apresentou tamanho médio de cerca de 2.5 a 3.0mm de altura e 3.5 a $4.0 \mathrm{~mm}$ de diâmetro. A maior parte dos pellets analisados apresentou-se relativamente preservada e quase $70 \%$ tinha coloração clara à amarelada, evidenciando uma recente entrada ao ambiente. As prováveis fontes desses pellets são as indústrias da região e o Porto de Santos, ambos situados no interior do estuário.

Como não existe uma metodologia que permita realizar amostragens quantitativas e comparáveis entre diferentes tipos de praia, foi fundamental que um estudo básico com este intuito fosse realizado. Embora existam alguns trabalhos que comparem a abundância de pellets entre praias, as metodologias utilizadas são bastante variáveis e permitem apenas comparações semi-quantitativas. Assim, este estudo representou a primeira tentativa de reunir informações sobre a contaminação do ambiente marinho brasileiro, mais especificamente em praias, por pellets. Os resultados deste estudo básico forneceram ainda informações relevantes para o desenvolvimento de ações mitigatórias e de manejo em relação aos resíduos plásticos no litoral brasileiro 
como um todo. Desta forma, poderá auxiliar o governo local e órgãos responsáveis, além do setor privado envolvido (indústrias de plásticos, por exemplo), a avaliarem os métodos de produção, processamento e transporte dos pellets e a determinarem medidas consistentes para controlar e prevenir sua perda para o ambiente.

A necessidade de investigações futuras sobre a distribuição e abundância dos pellets nas praias do Estado de São Paulo é crucial para a descoberta do real impacto dos pellets nesta região, tanto econômico quanto ambiental. Como desdobramento do projeto são necessários avaliar os efeitos físicos, químicos e ecológicos dos pellets no ambiente, além de realizar contatos com as empresas situadas próximo à área de estudo para um eficaz levantamento dos processos que envolvem os pellets e para que os pontos de perda destes para o mar sejam diagnosticados e mitigados; análises químicas mais aprofundadas, tanto na composição dos pellets quanto na concentração de substâncias tóxicas adsorvidas; e análises de conteúdo estomacal de aves costeiras e animais que eventualmente sejam depositados nas praias, com o intuito de verificar se e em que proporção essas partículas estão sendo ingeridas e levando-os à morte.

Estes pellets não são removidos pelos tratores ou rastelos utilizados na limpeza, se acumulando nas áreas mais altas da praia ao serem levados na maré alta ou em eventos de tempestade, de forma que podem ser um indicador crônico de poluição e não agudo, como é o caso dos dados de balneabilidade. Além disso, estudos sobre abundância de resíduos sólidos em praias têm as vantagens de apresentar um custo baixo, maior facilidade nos processos de amostragem além da maior capacidade de amostrar áreas relativamente extensas em comparação com estudos aquáticos (Santos et al., 2009). Portanto, diagnosticar e monitorar a qualidade de pellets em praias pode corresponder e um procedimento adicional estratégica na determinação da qualidade ambiental dessas áreas marinhas.

Foi levantado por um pesquisador norte-americano que, se grande quantidade de pellets continuasse a ser depositada em certas praias da Nova Zelândia, algum dia as pessoas naquela área estariam banhando-se em praias de plástico ao invés de praias de areia. "Nós ainda damos pouca importância a esta ameaça, já que está fora do alcance dos olhos da humanidade e, portanto, das nossas mentes” (Watson, 2001). Esse é o tipo de impacto que esse trabalho procurou entender e ajudar a solucionar. 


\section{REFERÊNCIAS BIBLIOGRÁFICAS}

ABESSA, D. M. S.; IMAI, R. S.; HARARI, J. Toxicidade da água na Baía de Santos. 2009. In: BRAGA, E. S. (ed). Oceanografia e Mudanças Globais. Anais do III Simpósio Brasileiro de Oceanografia. São Paulo: IOUSP e FAPESP, p. 659668.

ABU-HILAL, A. H.; AL-NAJJAR, T. 2004. Litter pollution on the Jordanian shores of the Gulf of Aqaba (Red Sea). Mar. Environ. Res., v. 58, n. 1, p. 39-63.

AGNELLI, J. A. M. 1996. Reciclagem de Polímeros: Situação Brasileira. Polímeros: Ciênc. Tecnol., v. 4, p. 9.

ANANTHASWAMY, A. 2001. Junk food - A diet of plastic pellets plays havoc with animals immunity. New Scient., v. 169, n. 2274, p. 18.

ANDRADY, A. L. 2000. Plastics and their Impacts in the Marine Environment. In: Proceedings of the International Marine Debris Conference on the Derelict Fishing Gear and the Ocean Environment, Hawaii Convention Center, Honoloulou, Hawaii.

ARAÚJO, M. C. B.; COSTA, M. 2004. Quali-quantitative analysis of the solid wastes at Tamandaré Bay, Pernambuco-Brasil. Trop. Oceanogr., v. 32, n. 2, p. 159170.

ARNOULD, J. P. Y.; CROXALL, J. P. 1995. Trends in Entanglement of Antarctic Fur Seals (Arctocephalus gazella) in Man-Made Debris at South Georgia. Mar. Pollut. Bull., v. 30, n. 11, p. 707-712.

AUMAN, H. J.; LUDWIG, J. P.; GIESY, J. P.; COLBORN, T. 1997. Plastic ingestion by Laysan Albatross chicks on Sand Island, Midway Atoll, in 1994 e 1995. In: ROBINSON, G.; GALES, R. (eds). Albatross: Biology and Conservation. Chipping Norton: Surrey Beatty and Sons. p. 239-244.

AZZARELLO, M. Y.; VAN-VLEET, E. S. 1987. Marine Birds and Plastic Pollution. Mar. Ecol. Progr. Ser., v. 37, p. 295-303.

BALAZS, G. H. 1985. Impact of ocean debris on marine turtles: Entanglement and ingestion. In: SHOMURA, R. S.; YOSHIDA, H. O. (eds). Proceedings of the Workshop on the Fate and Impact of Marine Debris, Honolulu, p. 387-429.

BARBIERI, E. 2009. Occurrence of Plastic Particles in Procellariiforms, South of São Paulo State (Brazil). Braz. Arch. Biol. Technol., v. 52, n. 2, p. 341-348. 
BAUM, B. 1974. The weathering degradation of polyolefins. Poly. Engng. Sci., v. 14, p. 206-211.

BJORNDAL, K. A.; BOLTEN, A. B.; LAGUEUX, C. 1994. Ingestion of marine debris by juvenile sea turtles in coastal Florida habitats. Mar. Pollut. Bull., v. 28, n. 3, p. 154-158.

BLIGHT, L. K.; BURGER, A. E. 1997. Occurrence of plastic particles in seabirds from de Eastern North Pacific. Mar. Pollut. Bull., v. 34, n. 5, p. 323-325.

BONETTI, J. 2000. Foraminíferos como bioindicadores do gradiente de estresse ecológico em ambientes costeiros poluídos. Estudo aplicado ao sistema estuarino de Santos - São Vicente (SP, Brasil). Tese de Doutorado. Universidade de São Paulo, Instituto Oceanográfico, São Paulo. 229 p.

BOURNE, W. R. P.; IMBER, M. J. 1982. Plastic pellets collected by a prion on Gough Island, Central South Atlantic Ocean. Mar. Pollut. Bull., v. 13, n. 1, p. 20-21.

BOWMAN, D.; MANOR-SAMSONOV, N.; GOLIK, A. 1998. Dynamics of litter pollution on Israeli Mediterranean Beaches: a budgetary, litter flux approach. J. Coast. Res., v. 14, n. 2, p. 418-432.

BUGONI, L.; KRAUSE, L.; PETRY, M. V. 2001. Marine debris and human impacts on sea turtles in Southern Brazil. Mar. Pollut. Bull.; v. 42, n. 12, p. 1330-1334.

CAMARGO, R.; HARARI, J.; CARUZZO, A. 1999. Basic statistics of storm surges over the South-Western Atlantic. Afro Am. GLOSS news, v. 3, n. 2, p. 12-14.

CANEVAROLO, S. V. 2004. Técnicas de Caracterização de Polímeros. São Paulo: ArtLiber Editora Ltda. 448 p.

CARPENTER, E. J.; ANDERSON, S. J.; HARVEY, G. R.; MIKLAS, H. P.; PECK, B. B. 1972. Polystyrene spherules in coastal waters. Sci., v. 178, p. 749-750.

CARPENTER, E. J.; SMITH, K. L. 1972. Plastics on the Sargasso Sea surface. Sci., v. 175, p. 1240-1241.

CARR, A. 1987. Impact of nondegradable marine debris on the ecology and survival outlook of sea turtles. Mar. Pollut. Bull., v. 18, n. 6B, p. 352-356.

CMC, 1988. A citizen's guide to plastic in the ocean: more than a litter problem. $3^{\text {rd }}$. edition. Center for Marine Conservation, Washington, DC. 143 p.

COE, J. M.; ROGERS, D. B. 1997. Consideration the land-based sources of debris. In: COE, J. M.; ROGERS, D. B. (eds). Marine Debris: Sources, Impacts and Solutions. Springer Series on Environmental Managment-Verlag, New York, p. 289-291. 
COLABUONO, F. I.; BARQUETE, V.; DOMINGUES, B. S.; MONTONE, R. C. 2009. Plastic ingestion by Procellariiformes in Southern Brazil. Mar. Pollut. Bull., v. 58, p. 93-96.

COLE, C. A.; KUMER, J. P.; MANSKI, D. A.; RICHARDS, D. V. 1990. Annual Report of National Park Marine Debris Monitoring Program: 1989 Marine Debris Survey. Tech. Rep. Department of the Interior National Park Service. Washington, DC, $31 \mathrm{p}$.

COLTON, J.B.; KNAPP, F. D.; BURNS, B. R. 1974. Plastic particles in surface waters of the Northwestern Atlantic. Sci., v. 185, p. 491-497.

CONNORS, P. G.; SMITH, K. G. 1982. Oceanic plastic particle pollution: suspected effect on fat deposition in Red Phalaropes. Mar. Pollut. Bull., v. 13, p. 18-20.

CORCORAN, P. L.; BIESINGER, M. C.; GRIFI, M. 2009. Plastics and beaches: A degrading relationship. Mar. Pollut. Bull., v. 58, p. 80-84.

COSTA, M. F.; IVAR DO SUL, J. A.; SILVA-CAVALCANTI, J. S.; ARAÚJO, M. C. B.; SPENGLER, A.; TOURINHO, P. S. 2009. On the importance of size of plastic fragments and pellets on the strandline: a snapshot of a Brazilian beach. Environ. Monit. Assess., publicado on line.

DAEE (Departamento de Águas e Energia Elétrica). 1999. Banco de dados pluviográficos do estado de São Paulo. In: Fundação do centro Tecnológico de Hidráulica - USP. CD-ROOM.

DAY, R. H. 1980. The occurrence and characteristics of plastic pollutions in Alaska's marine birds. Dissertação de Mestrado. University of Alaska, Fairbanks, AK, 111 p.

DHN - Diretoria de Hidrografia e Navegação. Carta Náutica do Porto de Santos. Marinha do Brasil, Divisão de Hidrografia e Navegação, Edição de 2003.

DEBROT, A. O., TIEL, A. B.; BRADSHAW, J. E. 1999. Beach Debris in Curacao. Mar. Pollut. Bull., v. 38, n. 9, p. 795-801.

DEFEO, O; RUEDA, M. 2002. Spatial structure, sampling design and abundance estimates in sandy beach macroinfauna: some warnings and new perspectives. Mar. Biol., v. 140, p. 1215-1225.

DERRAIK, J. G. B. 2002. The pollution of the marine environment by plastic debris: a review. Mar. Pollut. Bull., v. 44, n. 9, p. 842-852.

EMERY, K. O. 1961. A simple method of measuring beach profiles. Limnol. Oceanogr., v. 6, n. 1, p. 90-93. 
ENDO, S.; TAKIZAWA, R.; OKUDA, K., TAKADA, H.; CHIBA, K.; KANEHIRO, H.; OGI, H.; YAMASHITA, R.; DATE, T. 2005. Concentration of polychlorinated biphenyls (PCBs) in beached resin pellets: Variability among individual particles and regional differences. Mar. Pollut. Bull., v. 50, n. 10, p. 1103-1114.

EPA. 1990a. Methods to Manage and Control Plastic Wastes. Report to the Congress.

Washington: EPA/530-SW-89-051. Environmental Protection Agency.

EPA. 1990b. The Study of Floatable Debris in U.S. Waters (Harbor Studies Program), November 1988 through February 1989. Washington: EPA503/4-90-003, 193 p. + appendices. Environmental Protection Agency.

EPA. 1992a. Plastics Pellets in the Aquatic Environment: Sources and recommendations. Washington: EPA/842-B-92-010. Final Report. Environmental Protection Agency.

EPA. 1992b. The Study of Floatable Debris in U.S. Waters (Harbor Studies Program), March 1989 through April 1991. Washington: EPA842-R-92-001, 242 p. + appendices. Environmental Protection Agency.

EPA. 1992c. Harbor Studies Program Survey at Honolulu, Hawaii, and Kahana Bay Beach Observations, February 1992. Duxbury: Contract No. 68-C8-0105, 50 p. + appendices. Environmental Protection Agency.

ERICKSSON, C.; BURTON, H. 2003. Origins and biological accumulation of small plastic particles in fur seals from Macquarie Island. AMBIO, v. 32, n. 6, p. 380-384.

FRY, D. M.; FEFER, S. I.; SILEO, L. 1987. Ingestion of plastic debris by Laysan Albatrosses and Wedge-tailed Shearwaters in the Hawaiian-Islands. Mar. Pollut. Bull., v. 18, n. 6B, p. 339-343.

FURNESS, R. W. 1983. Plastic particles in three procellariiforme seabirds the beneguela current. Mar. Pollut. Bull., v. 14, p. 307-308.

FURNESS, R. W. 1985a. Plastic Particle Pollution - Accumulation by Procellariiform Seabirds at Scottish Colonies. Mar. Pollut. Bull., v. 16, n. 3, p. 103-106.

FURNESS, R. W. 1985b. Ingestion of plastic particles by seabirds at Gough-Island, South Atlantic Ocean. Environ. Pollut., v. 38, n. 3, p. 261-272.

FURNESS, R. W. 1994. Birds as monitors of pollutants. In: FURNESS R. W.; GREENWOOD, J. J. D., (eds). Birds as Monitors of Environmental Change. London: Chapman \& Hall, 356 p. 
GALGANI, F.; BURGEOT, T.; BOCQUENÉ, G.; VINCENT, E.; LEAUTÉ, J. P.; LABASTIE, J.; FOREST, A.; GUICHET, R. 1995a. Distribution and Abundance of Debris on the Continental Shelf of the Bay of Biscay and in Seine Bay. Mar. Pollut. Bull., v. 30, n. 1, p. 58-62.

GALGANI, F.; JAUNET, S.; CAMPILLOT, A.; GUENEGENT, X.; HIS, E. 1995b. Distribution and Abundance of Debris on the Continental Shelf of the NorthWestern Mediterranean Sea. Mar. Pollut. Bull., v. 31, n. 1, p. 713-717.

GARRITY, S. D.; LEVINGS, S.C. 1993. Marine debris along the Caribbean coast of Panama. Mar. Pollut. Bull., v. 26, p. 317-324.

GILLIGAN, M. R.; PITTS, S.; RICHARDSON, P. J.; KOZEL, T. R. 1992. Rates of accumulation of marine debris in Chatam County, Georgia. Mar. Pollut. Bull., v. 24, p. 436-441.

GOLDENSTEIN, L. 1972. A industrialização da Baixada Santista. Coleção Teses e Monografias, n. 7. Universidade de São Paulo, Instituto de Geografia, São Paulo, 342 p.

GOMES, C. M. B. 1973. Lançamento de partículas de polietileno a costa do Rio Grande do Sul. Rev. Veritas, v. 70, p. 174-204.

GORDON. M. 2006. Eliminating Land-based Discharges of Marine Debris in California: A Plan of Action from The Plastic Debris Project. Report. California Coastal Water Research Project (CCWRP), Plastic Debris, Rivers to Sea Project e Algalita Marine Research Foundation (AMRF). California, 91 p.

GREGORY, M. R. 1977. Plastic pellets on New Zealand beaches. Mar. Pollut. Bull., v. 8, p. 82-84.

GREGORY, M. R. 1978. Accumulation and distribution of virgin plastic granules on New Zealand beaches. N. Z. J. Mar. Fresh. Res., v. 12, n. 4, p. 399-414.

GREGORY, M. R. 1983. Virgin plastic granules on some beaches of Eastern Canada and Bermuda. Mar. Environ. Res., v. 10, n. 2, p. 73-92.

GREGORY, M. R. 1991. The hazards of persistent marine pollution: drift plastics and conservation islands. J. Res. Soc. N. Z., v. 21, p. 83-100.

GREGORY, M. R. 1999. Plastics and the South Pacific island shores: environmental implications. Ocean Coast. Manag., v. 4, n. 2, p. 603-615.

GREGORY, M. R.; RYAN, P. G. 1997. Pelagic plastics and other seaborne persistent synthetic debris: a review of Southern Hemisphere perspectives. In: COE, J. 
M.; ROGERS, D. B. (eds). Marine Debris - Sources, Impacts and Solutions, Springer-Verlag, USA, p. 49-66.

HARARI, J.; CAMARGO, R. 1995. Tides and mean sea level variabilities in Santos (SP), 1944 to 1989. Relatório Interno do Instituto Oceanográfico da USP, n. 36, $15 \mathrm{p}$.

HARARI, J.; CAMARGO, R. 1997. Simulações da circulação de maré na região costeira de Santos (SP) com modelo numérico hidrodinâmico. Pesquisa Naval Suplemento Especial da Rev. Marítima Brasileira, n. 10, p. 173-188.

HARARI, J.; CAMARGO, R., 1998. Modelagem numérica da região costeira de Santos (SP): circulação de maré. Rev. Bras. Ocean., v. 46, n. 2, p. 135-156.

HARARI, J.; CAMARGO, R.; CACCIARI, P. L. 1999. Implantação de um sistema de previsão de marés e de correntes de maré na Baixada Santista através de modelo numérico tridimensional. Relatório Técnico do Instituto Oceanográfico da USP, n. 45, 21 p.

HARARI, J.; CAMARGO, R.; CACCIARI, P. L. 2000. Resultados da modelagem numérica hidrodinâmica em simulações tridimensionais das correntes de maré na Baixada Santista. Rev. Bras. Rec. Hidric., v. 5, n. 2, p. 71-87.

HARARI, J.; CAMARGO, R.; MIRANDA, L. B. 2002. Modelagem numérica hidrodinâmica tridimensional da região costeira e estuarina de São Vicente e Santos (SP). Pesquisa Naval - Rev. Marítima Brasileira, v. 15, p. 79-97.

HARARI, J.; GORDON, M. 2001. Simulações Numéricas da Dispersão de Substâncias no Porto e Baía de Santos, sob a Ação de Marés. Rev. Bras. Rec. Hídric., v. 6, n. 4, p. 115-131.

HAYS, H.; CORMONS, G. 1974. Plastic particles found in tern pellets, on coastal beaches, and at factory sites. Mar. Pollut. Bull., v. 5, n. 3, p. 44-46.

HORTELLANI, M. A.; SARKIS, J. E. S.; ABESSA, D. M. S.; SOUSA, E. C. P. M. 2008. Avaliação da contaminação por elementos metálicos dos sedimentos do Estuário Santos-São Vicente. Quím. Nova, v. 31, n. 1, p. 10-19.

IBGE. Anuário estatístico dos municípios. 2007. Disponível em: $<$ http://www.ibge.gov.br/home/estatistica/populacao/contagem2007/popmunic 2007layoutTCU14112007.xls> Acesso em: 13 out. 2009.

ITF. Report of the Interagency Task Force on Persistent Marine Debris. Washington: s.n., 1988. 170 p. Chair, Interagency Task Force, Department of Commerce, National Oceanic and Atmospheric Administration. 
IVAR DO SUL, J. A.; SPENGLER, A.; COSTA, M. F. 2009. Here, there and everywhere. Small plastic fragments and pellets on beaches of Fernando de Noronha (Equatorial Western Atlantic). Mar. Pollut. Bull., v. 58, p. 12291244.

JONES, M. M. 1995. Fishing debris in the Australian marine environment. Mar. Pollut. Bull., v. 30, n. 1, p. 25-33.

KANEHIRO, H.; TOKAI, T.; MATUDA, K. 1995. Marine litter composition and distribution on the seabed of Tokyo Bay. Fish. Engng., v. 31, n. 1, p. 95-199.

KARAPANAGIOTI, H. K.; KLONTZA, I. 2007. Investigating the properties of plastic resin pellets found in the coastal areas of Lesvos Island. Global Nest. J., v. 9, n. 1, p. 71-76.

KARTAR, S.; MILNE, R. A.; SAINSBURY, M. 1973. Polystyrene waste in the Severn Estuary. Mar. Pollut. Bull., v. 4, p. 144.

KHORDAGUI, H. K.; ABU-HILAL, A. H. 1994. Industrial Plastic on the Southern Beaches of the Arabian Gulf and the Western Beaches of the Gulf of Oman. Environ. Pollut., v. 84, n. 3, p. 325-327.

KRUL, R.; MORAES, V. S. 1998. Efeitos de atividades humanas sobre populações de aves costeiras e oceânicas no litoral do Paraná. In: Congresso Brasileiro de Ornitologia, Rio de Janeiro: Sociedade Brasileira de Ornitologia, 105 p.

KURIYAMA, Y.; KONISHI, K.; KANEHIRO, H.; OTAKE, C.; KAMINUMA, T.; MATO, Y.; TAKADA, H.; KOJIMA, A. 2002. Plastic pellets in the marine environment of Tokyo Bay and Sagami Bay. Nippon Suisan Gakkaishi, v. 68, n. 2, p. $164-171$.

KUSUI, T.; NODA, M. 2003. International survey on the distribution of stranded and buried litter on beaches along the Sea of Japan. Mar. Pollut. Bull., v. 47, p. 175-179.

LAIST, D. W. 1987. Overview of the biological effects of lost and discarded plastic debris in the marine environment. Mar. Pollut. Bull., v. 18, n. 6B, p. 319-326.

LAIST, D. W. 1997. Impacts of Marine Debris: Entanglement of Marine Life in Marine Debris Including a Comprehensive List of species with Entanglement and Ingestion Records. In: COE, J. M.; ROGERS, D. B. (eds). Marine Debris: Sources, Impacts and Solutions. Springer Series on Environmental Management, Springer-Verlag, New York, p. 99-139. 
LIMA, A. M. F. 2001. Estudo da cadeia produtiva do Polietileno Tereftalato (PET) na Região Metropolitana de Salvador como subsídio para análise do ciclo de vida. Monografia (Curso de Especialização em Gerenciamento e Tecnologias Ambientais na Indústria). Escola Politécnica. Departamento de Hidráulica e Saneamento. Rede de Tecnologias Limpas (TECLIM). Universidade Federal da Bahia, Salvador.

MADZENA, A.; LASIAK, T. 1997. Spatial and temporal variations in beach litter on the Transkei coast of South Africa. Mar. Pollut. Bull., v. 34, p. 900-907.

MAGINI, C.; HARARI, J.; ABESSA, D. M. S. 2007. Circulação recente de sedimentos costeiros nas praias de Santos durante eventos de tempestades: dados para a gestão de impactos físicos costeiros. Geociências, v. 26, n. 4, p. 349-355.

MANO, E. B. 1999. Introdução a polímeros. 2a Ed. São Paulo: Ed. Edgard Blücher Ltda. 191 p.

MASCARENHAS, R.; BATISTA, C. P.; MOURA, I. F.; CALDAS, A. R. COSTA NETO, J. M.; VASCONCELOS, M. Q.; ROSA, S. S.; BARROS, T. V. S. 2008. Lixo marinho em área de reprodução de tartarugas marinhas no Estado da Paraíba (Nordeste do Brasil). Rev. Gestão Costeira Integrada, v. 8, n. 2, p. 221-231.

MASÓ, M.; GARCÉS, E.; PAGÈS, F.; CAMP, J. 2003. Drifting plastic debris as a potential vector for dispersing harmful algal bloom (HAB) species. Sci. Mar., v. 67 , n. 1 , p. $107-111$.

MATO, Y.; ISOBE, T.; TAKADA, H.; KANEHIRO, H.; OTAKE, C.; KAMINUMA, T. 2001. Plastic resin pellets as a transport medium for toxic chemicals in the marine environment. Environ. Sci. Technol., v. 35, n. 2, p. 318-324.

MATO, Y.; TAKADA, H.; ZAKARIA, M. P.; KURIYAMA, Y.; KANEHIRO, H. 2002. Toxic chemicals contained in plastic resin pellets in the marine environment - spatial difference in pollutant concentrations and the effects of resin type. Environ. Sci., v. 15, p. 415-423.

MCDERMID, K. J.; MCMULLEN, T. L. 2004. Quantitative analysis of small-plastic debris on beaches in the Hawaiian archipelago. Mar. Pollut. Bull., v. 48, n. 7-8, p. $790-794$.

MILLER, K. L.; HOMER, B.; BARBARITO, B.; DUNCAN, C.; PEARCE, A. 2003. Actions to combat the plastic pellet nuisance on beaches in the Firth of Forth, Scotland. Forth Estuary Forum Short Communication. 
MOORE, C. J. Plastic is Drastic: World's Largest 'Landfill' is in the Middle of the Ocean. Aboard Oceanographic Research Vessel, Alguita. Marine Research Foundation. 2002. Disponível

em: $<$ http://www.mindfully.org/Plastic/Ocean/Ocean-Plastic-LandfillAlgalita1nov02.htm>. Acesso em: 26 set. 2006. Algalita Marine Research Foundation (AMRF).

MOORE, S. L.; ALLEN, M. J. 2000. Distribution of Anthropogenic and Natural Debris on the Mainland Shelf of the Southern California Bight. Mar. Pollut. Bull., v. 40, n. 1, p. 83-88.

MOORE, S. L.; GREGORIO, D.; CARREON, M.; WEISBERG, S. B.; LEECASTER, M. K. 2001a. Composition and distribution of beach debris in Orange County, California. Mar. Pollut. Bull., v. 4, n. 2, p. 241-245.

MOORE, C. J.; MOORE, S. L.; LEECASTER, M. K.; LATTIN, G.; ZELLERS, A. 2002. A comparison of neustonic plastic and zooplankton abundance in southern California’s coastal waters. Mar. Pollut. Bull., v. 44, p. 1035-1038.

MOORE, C. J.; MOORE, S. L.; LEECASTER, M. K.; WEISBERG, S. B. 2001b. A Comparison of Plastic and Plankton in the Pacific Central Gyre. Mar. Pollut. Bull., v. 42, p. 1297-1300.

MORRIS, R. J. 1980. Floating plastic debris in the Mediterranean. Mar. Pollut. Bull., v. 11, p. 125.

MORRIS, A. W.; HAMILTON, E. I. 1974. Polystyrene spherules in the Bristol Channel. Mar. Pollut. Bull., v. 5, p. 26-27.

MOSER, G. A. O.; GIANESELLA, S. M. F.; ALBA, J. J. B.; BÉRGAMO, A. L.; CORRÊA, F. M. P. S.; MIRANDA, L. B.; HARARI, J. 2005. Instantaneous transport of salt, nutrients, suspended matter and clorophyll - a in the tropical estuarine system of Santos. Bras. J. Oceanogr., v. 53, n. 3/4, p. 115-127.

NASH, A. D. 1992. Impacts of marine debris on subsistence fishermen - an exploratory study. Mar. Pollut. Bull., v. 24, n. 3, p. 150-156.

OGATA, Y. A.; TAKADA, H. A.; MIZUKAWA, K. A.; HIRAI, H. A.; IWASA, S. A.; ENDO, S. A.; MATO, Y. A.; SAHA, M. A.; OKUDA, K. A.; NAKASHIMA, A. A.; MURAKAMI, M. B.; ZURCHER, N. C.; BOOYATUMANONDO, R. D.; ZAKARIA, M. P. E.; DUNG, L. Q. F.; GORDON, M. G.; MIGUEZ, C. H.; SUZUKI, S. I.; MOORE, C. J.; KARAPANAGIOTI, H. K. K.; WEERTS, S. L.; MCCLURG, T. L.; BURRESM, E.; SMITH, W. N.; VAN 
VELKENBURG, M. O.; LANG, J. S. P.; LANG, R. C. P.; LAURSEN, D. Q.; DANNER, B. R.; STEWARDSON, N. S.; THOMPSON, R. C. T. 2009. International Pellet Watch: Global monitoring of persistent organic pollutants (POPs) in coastal waters. 1. Initial phase data on PCBs, DDTs, and HCHs. Marine Pollution Bulletin v. 58, p. 1437-1446.

PAGE, B.; MCKENZIE, J.; MCINTOSH, R.; BAYLIS, A.; MORRISSEY, A.; CALVERT, N.; HAASE, T.; BERRIS, M.; DOWIE, D.; SHAUGHNESSY, P. D.; GOLDSWORTHY, S. D. 2004. Entanglement of Australian sea lions and New Zealand fur seals in lost fishing gear and other marine debris before and after Government and industry attempts to reduce the problem. Mar. Pollut. Bull., v. 49, p. 33-42.

PELANDA, A. A. 2007. Impactos humanos sobre aves associadas a ecossistemas marinhos na costa paranaense. Universidade Federal do Paraná, 43 p.

PETRY, M. V.; FONSECA, V. S. S. 2002. Effects of human activities in the marine environment on seabirds along the coast of Rio Grande do Sul, Brazil. Ornitol. Neotrop., v. 13, p. 137-142.

PIANOWSKI, F. 1997. Resíduos sólidos e esférulas plásticas nas praias do Rio Grande do Sul-Brasil. Fundação Universidade do Rio Grande, Departamento de Oceanografia, $79 \mathrm{p}$.

PLOTKIN, P. T.; AMOS, A. F. 1990. Effects of anthropogenic debris on sea turtles in the northwestern Gulf of Mexico. In: SHOMURA, R. S.; YOSHIDA, H. O. (eds). Proceedings of the Workshop on the fate and impact of marine debris, Honolulu, Hawaii. p. 736-743.

PRUTER, A. T. 1987. Sources, quantities and distribution of persistent plastics in the marine environment. Mar. Pollut. Bull., v. 18, n. 6B, p. 305-310.

REDDY, M. S.; BASHA, S.; ADIMURTHY, S.; RAMACHANDRAIAH, G. 2006. Description of the small plastics fragments in marine sediments along the Alang-Sosiya shipbreaking yard, India. Estuar. Coast. Shelf Sci., v. 68, n. 3-4, p. 656-660.

REDFORD, D. P.; TRULLI. H. K.; e TRULLI, W. R. 1997. Sources of plastic pellets in the aquatic environment. In: COE, J.; ROGERS, D.B. (eds). Marine debris: Sources, Impacts and Solutions. Springer Series on Environmental Management, Springer-Verlag, New York, p. 335-343. 
RIOS, L. M.; MOORE, C.; JONES, P. R. 2007. Persistent organic pollutants carried by synthetic polymers in the ocean environment. Mar. Pollut. Bull., v. 54, p. 12301237.

ROBARDS M. D.; PIATT, J. F.; WOHL, K. D. 1995. Increasing frequency of plastic particles ingested by seabirds in the subarctic North Pacific. Mar. Pollut. Bull., v. 30, p. 151-157.

RYAN, P. G. 1988. The characteristics and distribution of plastic particles at the seasurface off the southwestern Cape Province, South Africa. Mar. Environ. Res., v. 15 , p. $249-273$.

RYAN, P. G.; CONNELL, A. D.; GARDNER, B. D. 1988. Plastic ingestion and PCBs in seabirds: Is there a relationship? Mar. Pollut. Bull., v. 19, n. 4, p. 174-176.

RYAN, P.G.; SWANEPOEL, D. 1995. Updating marine debris research in South Africa. Mar. Debris Worldwide, v. 1, p. 6-7.

SADOVE, S. S.; MORREALE, S. J. 1990. Marine mammal and sea turtle encounters with marine debris in the New York Bight and the Northeast Atlantic. In: SHOMURA, R. S.; YOSHIDA, H. O. (eds). Proceedings of the Workshop on the fate and impact of marine debris, Honolulu, Hawaii. p. 562-570.

SANTOS, I. R.; FRIEDRICH, A. C.; IVAR DO SUL, J. A. 2009. Marine Debris contamination along undeveloped tropical beaches from northeast Brazil. Environ. Monit. Assess., v. 148, p. 455-462.

SHAVER, D. J. 1991. Feeding ecology of wild and head-started Kemp's ridley sea turtles in South Texas waters. J. Herpetol., v. 25, p. 327-334.

SHIBER, J. G. 1979. Plastic pellets on the coast of Lebanon. Mar. Pollut. Bull., v. 10, p. 28-30.

SHIBER, J. G. 1982. Plastic pellets on Spain's Costa del Sol beaches. Mar. Pollut. Bull., v. 13, p. 409-412.

SHIBER, J. G. 1987. Plastic pellets and tar on Spain's Mediterranean beaches. Mar. Pollut. Bull., v. 18, n. 2, p. 84-86.

SHIBER, J. G; BARRALESRIENDA, J. M. 1991. Plastic Pellets, Tar, and Megalitter on Beirut Beaches, 1977-1988. Environ. Pollut., v. 71, n. 1, p. 17-30.

SONDOTECNICA, 1977. Comportamento hidráulico e sedimentológico do estuário santista. Ministério dos Transportes, Empresa de Portos do Brasil S. A., PETROBRAS e Instituto de Pesquisas Hidráulicas - INPH. 343 p. 
SOUZA, C. R. de G. 1997. As Células de Deriva Litorânea e a Erosão nas Praias do Estado de São Paulo. Tese de Doutorado. São Paulo: Universidade de São Paulo, 184 p.

SOUZA, C. R. de G.; SUGUIO, K. 1998. Método morfo-sedimentológico para a identificação de células de deriva litorânea. Geosul, Edição Especial, v. 14, n. 27, p. 243-247.

SOUZA, C. R. de G. 2007. Determination of net shore-drift cells based on textural and morphological gradations along foreshore of sandy beaches. J. Coast. Res., Special Issue 50. Proceedings of the $9^{\text {th }}$ International Coastal Symposium. Gold Coast, Australia, ISBN.

SPI. 1991. Operation clean sweep: A manual on preventing pellet loss. The Society of the Plastics Industry, Inc., Washington, DC. 36 p.

SPINACÉ, M. A. S.; DE PAOLI, M. A. S. 2005. The technology of polymer recycling. Quím. Nova, v. 28, p. 65-72.

STORRIER, K. L.; MCGLASHAN, D. J.; BONELLIE, S.; VELANDER, K. 2007. Beach litter deposition at a selection of beaches in the firth of forth, Scotland. J. Coast. Res., v. 23, p. 813-822.

THOMPSON, R. C.; OLSEN, Y.; MITCHELL, R. P.; DAVIS, A.; ROWLAND, S. J.; JOHN, A. W. G.; MCGONIGLE, D.; RUSSELL, A. E. 2004. Lost at sea: Where does all the plastic go? Sci., v. 304, p. 838.

TUDOR, D. T.; WILLIAMS, A. T. 2004. A review of litter sourcing methodologies and application of a matrix scoring technique. J. Coast. Conserv., v. 10, n. 1/2, p. 119-628.

TURRA, A; MALUF, A.; MANZANO, A. B. 2008. Invasão de plásticos nos oceanos. Ciência Hoje, v. 46, n. 246, p. 40-45.

UNDERWOOD, A. J. 1997. Experiments in ecology. Their logical design and interpretation using analysis of variance. Institute of Marine Ecology, University of Sidney. Cambridge: Cambridge University Press. 499 p.

VAN FRANEKER, J. A. 1985. Plastic ingestion in the north Atlantic fulmar. Mar. Pollut. Bull., v. 16, n. 9, p. 367-369.

VAN FRANEKER, J. A; BELL, P. J. 1988. Plastic ingestion by petrels breeding in Antarctica. Mar. Pollut. Bull., v. 19, p. 672-674.

VOOREN, C. M.; BRUSQUE, L. F. 1999. Avaliação e ações prioritárias para a conservação da biodiversidade da zona costeira e marinhas: Diagnóstico sobre 
aves do ambiente costeiro do Brasil. Disponível em: <http://www.bdt.fat.org.br/workshop/costa/aves> Acesso em: 26 ago. 2009.

VOOREN, C. M.; FERNANDES, A. C. 1989. Guia de albatrozes e petréis do sul do Brasil. Porto Alegre: Sagra. 99 p.

WALLACE, 1985. Debris entanglement in the marine environment: A review. In: SHOMURA, R. S.; YOSHIDA, H. O. (eds). Proceedings of the Workshop on the Fate and Impact of Marine Debris, Honolulu, Hawaii. p. 259-277.

WATSON, P. Against the current - The Plastic Sea. 2001. Disponível em: <http://libaware.economads.com/plasticsea.php> Acesso em: 06 ago. 2009.

WETZEL, L.; FILLMANN, G.; NIENCHESKI, L. F. H. 2004. Litter contamination processes and management perspectives on the southern Brazilian coast Int. J. Environ. Pollut., v. 21, n. 2, p. 153-165.

WILBER, R. J. 1987. Plastic in the north Atlantic. Oceanus, v. 30, n. 3, p. 61-68.

WILLIAMS, A. T.; SIMMONS, S. L. 1997. Estuarine litter at the river/beach interface in the Bristol Channel, UK. J. Coast. Res., v. 13, n. 4, 1159-1165.

WILLIAMS, A. T.; SIMMONS, S. L. 1999. Sources of riverine litter: The River Taff, South Wales, UK. Water, Air \& Soil Pollut., v. 112, p. 197-216.

WILLIAMS, A. T.; TUDOR, D. T. 2001. Litter burial and exhumation: Spatial and temporal distribution on a cobble pocket beach. Mar. Pollut. Bull., v. 42, p. 1031-1039.

WILLIAMS, A. T.; GREGORY, M.; TUDOR, D. T. 2005. Marine debris - onshore, offshore, seafloor litter. In: SCHWARTZ, M., (ed.). Encyclopedia of coastal processes. Springer, p. 623-628.

WILLIAMS, A. T.; POND, K.; TUDOR, D. T.; JANSEN, H.; LIU, H. B. 1999. The robustness of litter transect data collection by different survey groups. In: OZHAN, E. (ed). Proc. of the MEDCOAST 9 - EMECS 99 Joint Conference: Land Ocean Interactions - Managing coastal ecosystems, Middle East Technical University, Ankara, Turkey. p. 715-726.

WILSON, S. P.; RANDALL, S. J. 2005. Patterns of Debris Movement: From an Urban Estuary to a Coastal Embayment. In: Proceedings of the 2005 Plastic Debris, Rivers to the Sea Conference, California.

ZAR, J. H. 1999. Bioestatistical analysis. New Jersey: Prentice-Hall Inc. 663 p. 


\section{ANEXOS}

Anexo I. Perfil praial (desnível) nas áreas de coleta para análise da variação do número de pellets ao longo da Enseada de Santos. Distância a partir do calçadão.

\begin{tabular}{|c|c|c|c|c|c|c|c|c|c|c|c|c|c|c|c|}
\hline \multirow{2}{*}{ Distância } & \multicolumn{15}{|c|}{ Área } \\
\hline & 1 & 2 & 3 & 4 & 5 & 6 & 7 & 8 & 9 & 10 & 11 & 12 & 13 & 14 & 15 \\
\hline $0 \mathrm{~m}$ & & & & & & & & & & & & & & & \\
\hline 5 & 15,0 & 5,5 & 6,0 & 19,5 & 1,0 & $-4,0$ & $-4,0$ & $-16,0$ & 6,0 & $-20,0$ & $-11,0$ & 1,0 & 4,0 & 11,0 & $-2,0$ \\
\hline 10 & 9,5 & 13,0 & 7,5 & 10,5 & 8,0 & $-8,0$ & $-9,0$ & 3,0 & $-6,0$ & $-7,0$ & $-8,0$ & 4,0 & 7,0 & 11,0 & 7,0 \\
\hline 15 & 13,0 & 13,0 & 6,0 & 10,0 & 3,0 & $-1,0$ & $-1,0$ & $-3,0$ & $-7,0$ & $-7,0$ & 4,0 & 5,0 & 6,0 & 6,0 & 2,0 \\
\hline 20 & 14,0 & 12,0 & 17,0 & 11,0 & 6,0 & $-2,0$ & $-3,0$ & $-13,0$ & $-4,0$ & $-8,0$ & $-11,0$ & 2,0 & 5,0 & 9,0 & 3,0 \\
\hline 25 & 10,0 & 11,5 & 4,5 & 11,0 & 7,0 & $-5,0$ & 6,0 & $-4,0$ & 2,0 & $-5,0$ & $-6,0$ & 3,0 & 5,0 & 9,0 & 4,0 \\
\hline 30 & 8,0 & 9,0 & 14,5 & 8,0 & 8,0 & $-4,0$ & 12,0 & $-1,0$ & 4,0 & $-0,5$ & 6,0 & 2,0 & 7,0 & 7,0 & 6,0 \\
\hline 35 & 8,5 & 10,5 & 9,0 & 5,0 & 10,0 & $-3,0$ & $-1,0$ & 3,0 & $-4,0$ & $-1,0$ & 7,0 & 2,0 & 6,0 & 7,0 & 4,0 \\
\hline 40 & 7,5 & 11,0 & 10,0 & 8,0 & 10,0 & $-1,0$ & 3,0 & $-12,0$ & $-3,0$ & 7,0 & 3,0 & 3,0 & 5,0 & 6,0 & 6,0 \\
\hline 45 & 6,0 & 10,0 & 8,0 & 6,0 & 9,0 & 6,0 & 3,0 & 9,5 & 1,0 & 8,0 & 0,5 & 5,0 & 6,0 & 8,0 & 12,0 \\
\hline 50 & 7,0 & 8,0 & 5,0 & 3,0 & 5,0 & 12,0 & 4,0 & 2,0 & $-4,0$ & 11,0 & 8,5 & 6,0 & 4,0 & 8,0 & 2,0 \\
\hline 55 & & & & $-2,0$ & & 15,0 & $-6,0$ & 3,0 & 6,0 & 8,0 & 10,0 & 6,0 & 6,0 & 9,0 & 5,0 \\
\hline 60 & & & & 14,0 & & 11,0 & 6,0 & 6,0 & 4,0 & 9,0 & 10,0 & 7,0 & 5,0 & 9,0 & 6,0 \\
\hline 65 & & & & & & 7,0 & 2,0 & 4,0 & 8,0 & 4,0 & 5,0 & 7,0 & 5,0 & & 12,0 \\
\hline 70 & & & & & & 7,0 & 5,0 & 6,0 & 14,0 & 6,0 & 9,0 & 6,0 & 5,0 & & 9,0 \\
\hline 75 & & & & & & 8,0 & 5,0 & 5,0 & 8,0 & 5,0 & 5,0 & & & & \\
\hline 80 & & & & & & 9,0 & 7,5 & 4,0 & 5,0 & 6,0 & 5,0 & & & & \\
\hline 85 & & & & & & 7,0 & 1,5 & 4,0 & 7,0 & 5,0 & 6,0 & & & & \\
\hline 90 & & & & & & 7,0 & 1,0 & 5,0 & 5,0 & 10,0 & 8,0 & & & & \\
\hline 95 & & & & & & & & 5,0 & 6,0 & & 7,0 & & & & \\
\hline 100 & & & & & & & & 4,0 & 7,0 & & 6,0 & & & & \\
\hline Total & $\mathbf{9 8 , 5}$ & 103,5 & 87,5 & 104,0 & 67,0 & 61,0 & 34,5 & 14,5 & 55,0 & 30,5 & 64,0 & 59,0 & 76,0 & 100,0 & 76,0 \\
\hline
\end{tabular}

